Historic, archived document

Do not assume content reflects current scientific knowledge, policies, or practices. 



\section{Potential for Producing}

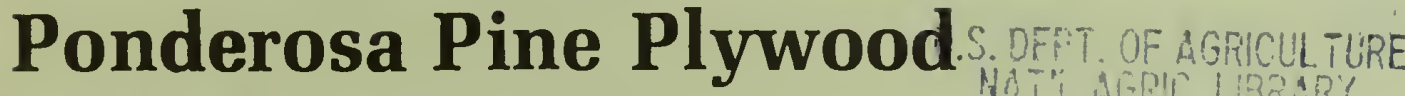 in the Black Hills}

Dennis M. Donnelly and Harold E. Worth

Hin $\angle 6 \quad 62$

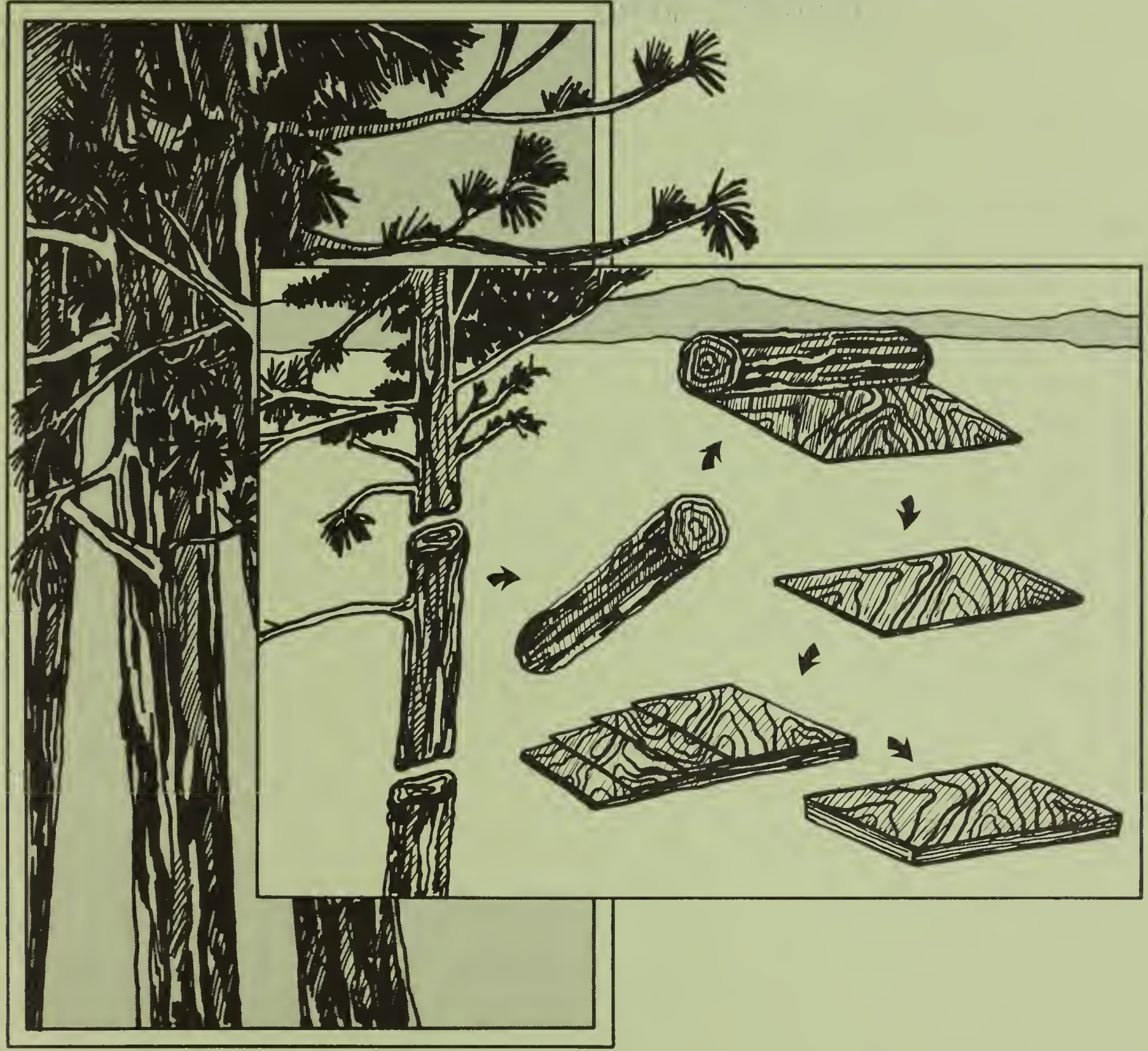

Resource Bulletin RM-4

Rocky Mountain Forest and

Range Experiment Station

Forest Service

U.S. Department of Agriculture 


\begin{abstract}
This study describes possible plywood production opportunities for Black Hills ponderosa pine in terms of kinds of plywood and advantageous market areas. The resource analysis examines current and future uses of the area's timber. Economic evaluation includes analyses of discounted cash flow and operating costs and revenues.
\end{abstract}

The use of trade and company names is for the benefit of the reader; such use does not constitute an official endorsement or approval of any service or product by the U.S. Department of Agriculture to the exclusion of others that may be suitable.

\title{
Acknowledgments
}

The resource section of this report is based in part on earlier work by Vern P. Yerkes, USDA Forest Service Southwest Region, and Richard O. Woodfin, USDA Forest Service Pacific Northwest Forest and Range Experiment Station, and their contributions are cited in the text. The economics section is based on a projection of investment and operating costs by F. E. Hahn, formerly with H. C. Mason and Associates. In addition, the authors thank the following people for their assistance: Robert G. Anderson (American Plywood Association), Richard F. Baldwin (Champion International Corporation), and James L. Bowyer (University of Minnesota). 


\section{Potential for Producing Ponderosa Pine Plywood in the Black Hills}

Dennis M. Donnelly, Systems Analyst

and

Harold E. Worth, Principal Market Analyst

Rocky Mountain Forest and Range Experiment Station' 


\section{Contents}

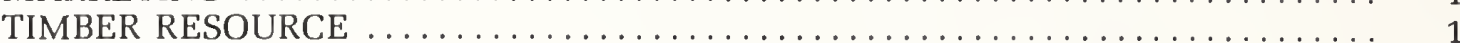

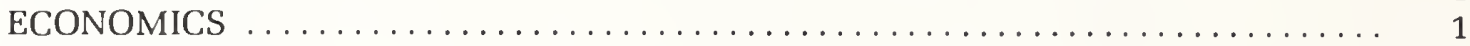

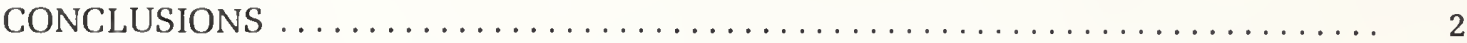

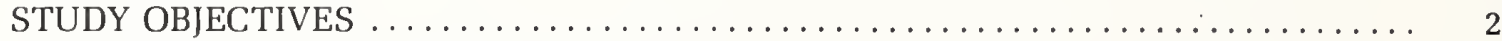

MARKETS FOR BLACK HILLS PLYWOOD . . . . . . . . . . . . . . . . . 2

U.S. PLYWOOD MARKET CHANGES . . . . . . . . . . . . . . . . . . . 2

NATIONAL PLYWOOD OUTLOOK $\ldots \ldots \ldots \ldots \ldots \ldots \ldots \ldots \ldots \ldots \ldots \ldots \ldots \ldots$

End-Use Markets .................................... 3

End-Use Markets and Plywood Grades ................................. 3

PONDEROSA PINE PLYWOOD-POTENTIAL APPLICATIONS $\ldots \ldots \ldots \ldots \ldots \ldots \ldots$.

Residential Construction .................................. 3

Industrial, Nonresidential, and Other Uses ..................... 4

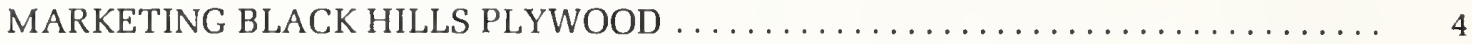

Production and Demand in Relation to Geography $\ldots \ldots \ldots \ldots \ldots \ldots \ldots \ldots \ldots . \ldots$

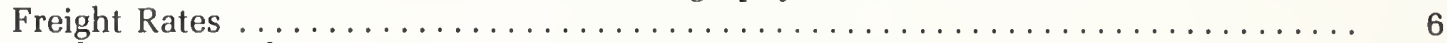

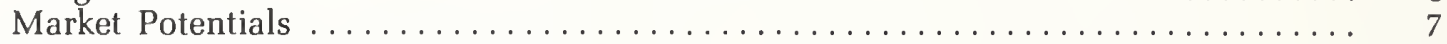

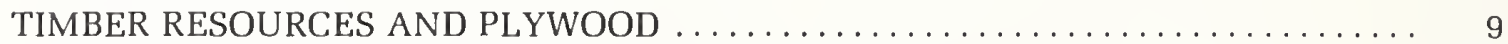

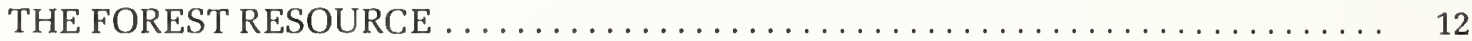

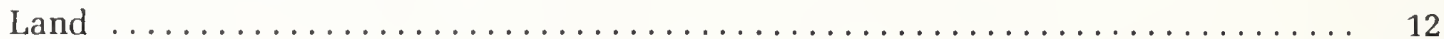

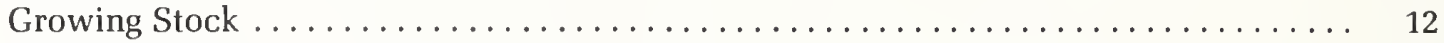

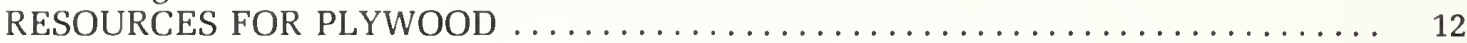

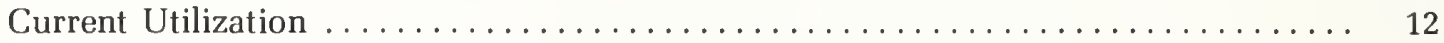

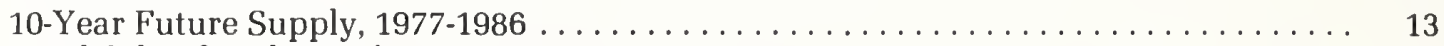

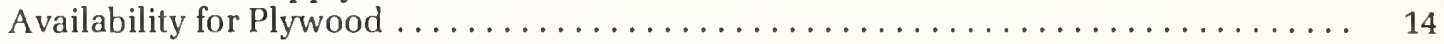

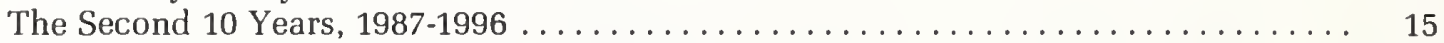

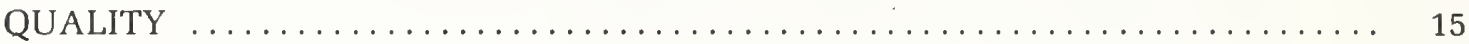

Timber Sale Characteristics ................................ 15

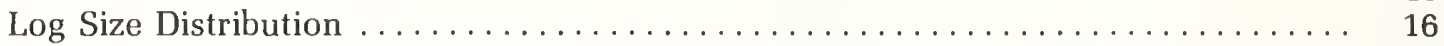

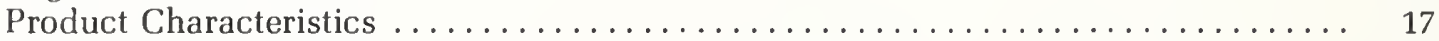

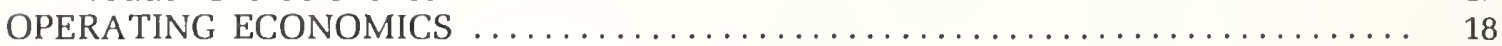

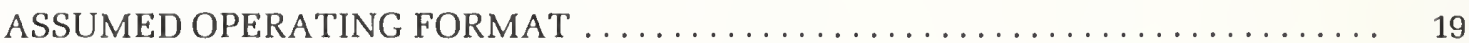

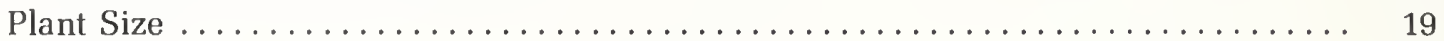

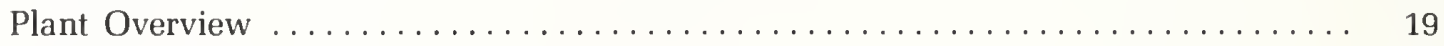

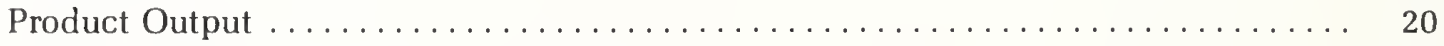

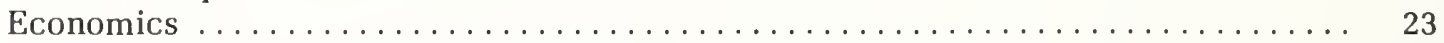

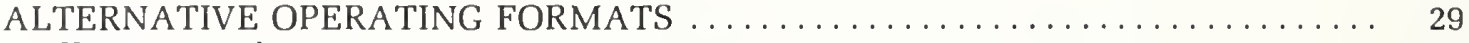

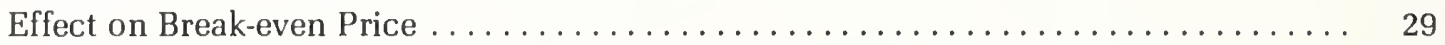

Effect on Raw Material Need ................................ 29

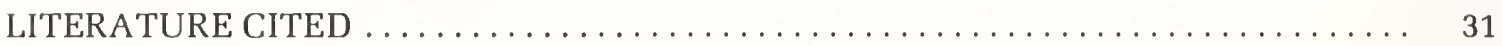

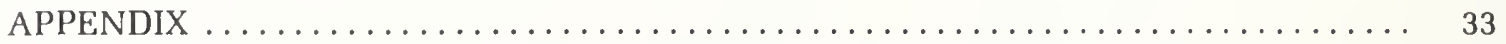

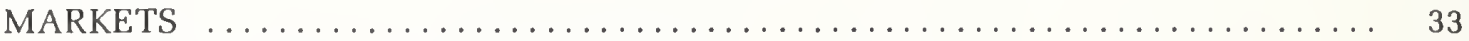

Plywood Properties Important in Marketing ..................... 33

Applications in Residential Construction . . . . . . . . . . . . . . . . . . 34

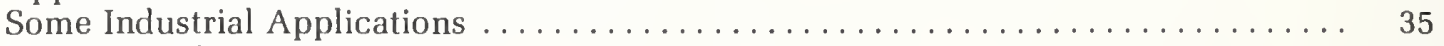

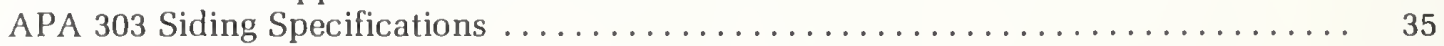

TIMBER RESOURCE ........................................ 36

Black Hills National Forest Timber Classes . . . . . . . . . . . . . . . . . . . 36

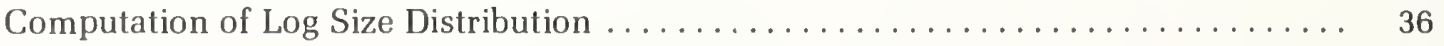

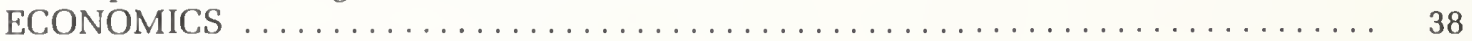

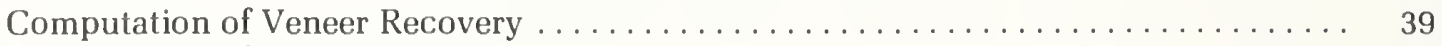

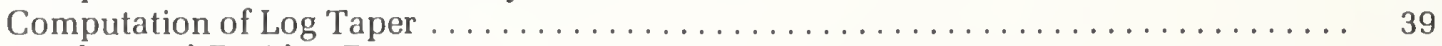

Lumber and Residue Recovery ............................ 40

Bark Volume ......................................... 40

Product Recovery for Index Log

Volumes and Total Volume Required $\ldots \ldots \ldots \ldots \ldots \ldots \ldots \ldots \ldots \ldots \ldots \ldots \ldots \ldots$ 


\title{
Potential for Producing Ponderosa Pine Plywood in the Black Hills
}

\author{
Dennis M. Donnelly and Harold E. Worth
}

\section{MANAGEMENT IMPLICATIONS}

\section{MARKETING}

A major advantage of producing plywood in the Black Hills area of South Dakota and Wyoming is proximity to major markets. Plywood produced there could be delivered to Great Plains and upper Midwest markets at a freight cost lower than that from other major softwood plywood producing regions. Market potentials for softwood plywood in the United States are very strong for the foreseeable future. However, because ponderosa pine is not a well established plywood species, there is some question about the share of the market it can command. Because Black Hills ponderosa pine yields primarily $C$ and $D$ grade veneers, its utilization would be limited mainly to plywood products made from these grades, such as roof and wall sheathing, siding, or flooring. Other special plywood products for use in new residential, homeowner, nonresidential construction, and industrial markets seem promising also. Small volumes of B Patch and better veneer might be marketed as stock for products where appearance is of some importance, such as cabinets.

In addition, recent developments in performance standards for sheathing panels, including plywood, may have expanded market possibilities for woods such as ponderosa pine. Performance-rated sheathing panels are "designed, manufactured and identified for specific construction end uses" (American Plywood Association 1980). Such panels conform to "criteria for panel strength, stiffness, durability, stability and other properties relevant to the end-use." If structural criteria are met, panels can be made entirely from veneer faces bonded to a reconstituted wood core, or from reconstituted wood.

In the case of plywood manufactured from ponderosa pine in the Black Hills, the provisions of Product Standard 1-74 (American Plywood Association 1974) remain applicable. However, it is possible that such plywood could now obtain upgraded span ratings through testing for sheathing end-use applications. See the appendix for details about sheathing applications and span ratings. Plywood variables such as veneer thickness and orientation, along with inherent wood properties, would determine in part how well such panels meet the standards for performance-rated sheathing.

\section{TIMBER RESOURCE}

The Black Hills National Forest Timber Management Plan for the 10-year period ending in 1986 shows that enough timber of the required size ${ }^{2}$ is available to support a plywood plant with an annual capacity of about 60-65 million square feet $\left(\mathrm{MM} \mathrm{ft}^{2}\right), 3 / 8$-inch basis. However, a very tentative projection for the following 10-year period indicates sawtimber volume from 1987 to 1996 may be about 23 million board feet less than volume for the current 10 -year period-a $21 \%$ reduction. This reduction of volume in sawtimber size trees may mean a smaller potential supply of logs suitable for plywood.

The size of logs required for any potential plywood plant is roughly the same as for the established Black Hills lumber industry. The supply of timber of this size appears to be adequate to serve both the present industry and a new plywood plant until 1986. However, in the 10 years after 1986, reduced volumes of timber in this size class may not support both industries.

Estimated veneer block supply is concentrated largely in the 8- to 12 -inch d.i.b. ${ }^{3}$ range. A plywood plant would also have to deal with a substantial volume of logs smaller than 8 inches d.i.b. to utilize the tops of larger trees and any smaller trees purchased in multiproduct timber sales.

\section{ECONOMICS}

At early 1978 cost levels, the break-even price for 1,000 square feet of 1/2-inch C-D Interior plywood with external glue (C-D-X) sheathing, f.o.b. mill, was about $\$ 142$. For a $20 \%$ rise in total costs, break-even price for $1 / 2$-inch C-D-X sheathing rose $28 \%$. Break-even price is also sensitive to other factors, to a lesser degree. In decreasing order of sensitivity, internal rate of return, log cost, labor cost, and energy cost are of greatest importance. All costs are those incurred before the plywood leaves the mill.

The economic aspects of plywood manufacture in the Black Hills area appear favorable except for the uncer-

\footnotetext{
${ }^{2}$ The "required size" in this report is assumed to be trees whose diameter at 4.5 feet above the ground (diameter at breast height) is 9 inches or greater. Diameters of the timber resource analyzed in this report are grouped into 2-inch classes for which the nominal diameter is the mid-value (e.g., the 10-inch d.b.h. class includes all trees whose diameter is between 9.0 and 10.9 inches.

'Usually the small end of the log is specified for the diameter inside bark (d.i.b.) measurement.
} 
tainty surrounding supplies of logs for veneer. The analysis showed that under 1978 conditions, supplies of stumpage could be critical for both plywood and lumber. However, current total sawmill demand for stumpage has decreased significantly. It is possible that plywood manufacture would be economically attractive at this time.

\section{CONCLUSIONS}

The timber resource projected for harvest in the Black Hills area, during the next 15 years, is not adequate to support a plywood plant of economic size in addition to a sawmill industry of the size operating in early 1978. Under conditions existing at that time, competition for available sawtimber could be expected to intensify during the period, particularly after 1986. More recently, however, mill closures have resulted in substantial reductions in overall sawmill production, which could make plywood an attractive alternative for utilizing a potential surplus of sawtimber.

Markets do not appear to be a major problem, because the north-central part of the United States should provide good end-use outlets for plywood of the types that could be produced. Economic costs and returns would probably be favorable for a plywood producer at least until 1986, when the expected reduction in sawtimber volume could significantly increase competition and the cost of stumpage.

\section{STUDY OBJECTIVES}

The goal of this study was to evaluate marketing, timber resource and economic factors that determine whether plywood could be profitably manufactured in the Black Hills area of South Dakota and Wyoming. Specifically the study objectives were to:

1. Determine market potentials for selected plywood products that can be manufactured from Black Hills ponderosa pine.

2. Evaluate the timber resource of the Black Hills area in terms of its current utilization, its availability and suitability for veneer, and the log size classes available under current timber management plans.

3. Analyze the operating economics of a potential plywood plant/sawmill complex under several assumptions about product prices and plant costs.

\section{MARKETS FOR BLACK HILLS PLYWOOD}

\section{U.S. PLYWOOD MARKET CHANGES}

Since 1945, many new end uses have been developed for softwood plywood in the United States. The largest single use is structural sheathing for residential construction. In response to this increase in uses, the softwood plywood industry now has 10 times the production capacity of 30 years ago (Gregory 1972, Lambert 1977, U.S. Department of Commerce 1978a).
In 1950, the plywood industry manufactured about 2.7 billion square feet $\left(\mathrm{MMM} \mathrm{ft}^{2}\right)^{4}$ at a relative wholesale price index of $180(1967=100)$. Until 1968 , the plywood industry provided increasing supplies at decreasing relative prices because of efficiencies of scale, productivity gains, and increased industry competition (Gregory 1972). This relationship through the years until 1967 is shown in figure 1 by the steadily decreasing relative wholesale price index as production increased. However, starting in 1968, the relationship between relative wholesale price index and softwood plywood production became erratic because of several economic factors-primarily inflation, rising raw material costs and, especially, highly variable housing markets.

Production of sanded grades ${ }^{5}$ was about $2.6 \mathrm{MMM} \mathrm{ft}^{2}$ in 1976, $18 \%$ of total production (American Plywood Association 1977b). Production of specialty grades ${ }^{6}$ was about $1.5 \mathrm{MMM} \mathrm{\textrm {ft } ^ { 2 }}$ in $1976,10 \%$ of total production. Production of sheathing grades ${ }^{7}$ was about 10.7 $\mathrm{MMM} \mathrm{ft}^{2}$ in 1976, $72 \%$ of total production.

During the past 30 years, plywood, especially sheathing, has been substituted for lumber in housing

${ }^{4} A / l$ plywood production and volume figures in this report are based on 3/8-inch thickness unless otherwise noted.

${ }^{5}$ Sanded grades include $B-D$ and better sanded grades (American Plywood Association 1974).

${ }^{6}$ Specialty grades include siding, and other specialty products like $T$ 1-11, 303 sidings and overlays, and Plyron (American Plywood Association 1974).

${ }^{7}$ Sheathing grades include sheathing and touch sanded grades such as C-D-X, Underlayment, C-C, 2-4-1, Structural I and II, and C-D P \& TS (American Plywood Association 1974).

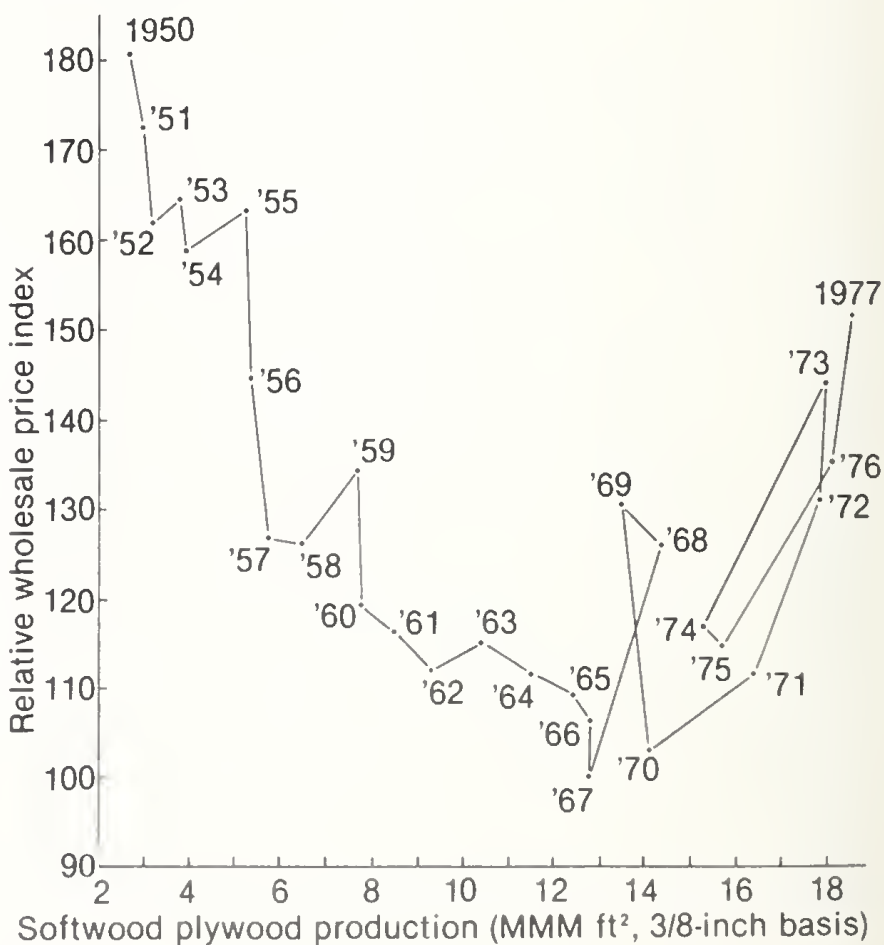

Figure 1.-Production of softwood plywood from 1950 to 1977 relative to its wholesale price index. Data Source: Phelps (1977), and U.S. Department of Commerce (1978b). Acknowledgement is made of the original form of this graph appearing in Gregory (1972). 
construction. This shift accounts for the dominance of sheathing grades among all types of softwood plywood.

\section{NATIONAL PLYWOOD OUTLOOK}

Although the maturing plywood industry may not continue to experience the spectacular growth rate of the 25-year post-World War II period, industry sources expect continued expansion of production to meet increasing demand (Anderson 1977, Baldwin 1977). Housing growth is expected to continue to increase up to the late 1980's. However, wide cyclic swings may continue unless effective institutional means are adopted to even out production (Young 1978). New floor, foundation, and wall applications for plywood, such as the All Weather Wood Foundation or underfloor plenum heating-cooling systems, will probably strengthen plywood demand. Non-housing markets such as use by homeowners also are expected to create new plywood demand. ${ }^{8}$

Current (1980) plywood industry plant capacity, ${ }^{8}$ based on 3-shift, 5-day operation, is estimated at 24.46 MMM $\mathrm{ft}^{2}$. This current total capacity is slightly higher than a conservatively projected demand for the mid-1980's of about 22 MMM ft².

\section{End-Use Markets}

The five principal markets for softwood plywood, as defined by the American Plywood Association (APA) (Anderson 1977) are:

Residential construction.-Including single and multifamily homes, manufactured housing, and mobile homes.

Nonresidential construction.-Including most buildings not used as homes, such as commercial, industrial, and institutional buildings; hotels; motels; agricultural buildings; and applications such as barricades, signs, shoring, dams, bridges, and highways. Highrise apartment construction also is included in this end-use market.

Industrial.-Encompassing a wide variety of uses, such as manufactured products including furniture, fixtures, and toys. Pallets, crates, bins, and other containers, categorized as materials handling devices, are also included. The transportation industry uses plywood in truck bodies, cargo containers and liners, rail cars, ships, boats, and travel trailers. General industrial applications are for plant repair and maintenance, and for tools, jigs, and patterns.

Distribution (homeowner).-Including home repair and remodeling, home additions and alterations, and miscellaneous homeowner projects.

Miscellaneous.-The fifth market segment, including international markets, government and military markets, and any use not included in the other market sectors.

\footnotetext{
- Personal communication from Robert G. Anderson, Marketing Group, American Plywood Association, Tacoma Wash.
}

Of interest, is the projected change in demand for each of the five principal markets. Average growth or decline in each principal end-use market is indicated by a compound annual rate of demand change (table 1). For example, an estimated market share loss of $8.1 \%$ from 1977 to 1986 in the residential end-use market is taken up by market share gains in the other four enduse markets.

\section{End-Use Markets and Plywood Grades}

Some indication of future demand for individual plywood grades can be obtained by combining demand forecasts for end-use markets with information about plywood grades most used in those markets. Table 2 shows main segments of the five major plywood enduse markets along with plywood grades used predominantly in each market segment.

A Black Hills plywood plant, manufacturing panels with $C$ and $D$ grades of veneer, would have access to several market segments. Some degree of protection from market fluctuations would be afforded by this diversity.

Grades other than C-D-X that could be made from Black Hills ponderosa pine are Exterior C-C and Structural II C-C, C-C Plugged, and C-D; also Interior Structural II C-D, C-D Plugged, and Underlayment; also 2-4-1 and 2-4-1 T\&G. These grades have wide application by market sector, as shown in table 2 , and are relatively high in value; however, market demand is much smaller than for C-D or C-D-X grades.

In addition, new grade specifications for 303 siding may allow use of ponderosa pine for this product. Also, enough B Patch and better veneer can be recovered (Yerkes and Woodfin 1972) so that decorative panel products and cabinet grade plywood are production possibilities.

\section{PONDEROSA PINE PLYWOOD-POTENTIAL APPLICATIONS}

Ponderosa pine (Pinus ponderosa Laws.) is classified in U.S. Product Standard PS 1-74 as a Group 3 softwood plywood species (American Plywood Association 1974), based on stiffness and strength properties. Plywood characteristics and properties important in marketing and application are discussed in the appendix. Based on these characteristics and the APA classification, some of the uses for which ponderosa pine plywood should be suitable include sheathing, subflooring, underlayment, siding, soffits, signs, billboards, boxes, crates, movable partitions, interior paneling, and kitchen cabinets, furniture, fixtures, and decorative paneling. The following applications are discussed for each major end-use category that utilizes mostly $\mathrm{C}$ and $\mathrm{D}$ grades of veneer.

\section{Residential Construction}

Softwood plywood is primarily used in roof sheathing, subflooring, underlayment, combination flooring, 
Table 1.-Comparison of demand and market share in plywood end-use markets'

\begin{tabular}{|c|c|c|c|c|c|}
\hline $\begin{array}{l}\text { Major end-use } \\
\text { market }\end{array}$ & $\begin{array}{c}1977 \\
\text { demand }\end{array}$ & $\begin{array}{c}1986 \\
\text { estimated } \\
\text { demand }\end{array}$ & $\begin{array}{l}\text { Estimated } \\
\text { average } \\
\text { annual } \\
\text { demand } \\
\text { change } \\
1977.1986\end{array}$ & $\begin{array}{c}1977 \\
\text { market } \\
\text { share }\end{array}$ & $\begin{array}{c}1986 \\
\text { estimated } \\
\text { market } \\
\text { share }\end{array}$ \\
\hline & \multicolumn{2}{|c|}{ MMM $f t^{2}$} & (n) & percent & 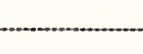 \\
\hline Residential & 9.10 & 8.85 & -0.28 & 46.8 & 38.7 \\
\hline Distribution (homeowner) & 3.60 & 4.55 & 2.37 & 18.5 & 19.9 \\
\hline Industrial & 3.00 & 4.10 & 3.17 & 15.4 & 17.9 \\
\hline Nonresidential & 2.25 & 3.10 & 3.26 & 11.6 & 13.6 \\
\hline Other & 1.50 & 2.25 & 4.14 & 7.7 & 9.8 \\
\hline Total & 19.45 & 22.85 & ${ }^{21} .62$ & 100.0 & 100.0 \\
\hline
\end{tabular}

'Source: Anderson (1977).

${ }^{2}$ This figure is the average for all major end-use markets.

wall sheathing, siding, and combination siding. These uses make up almost $90 \%$ of the plywood sold in the residential construction market. Most of the potential construction uses for ponderosa pine plywood are subject to local building codes, which establish the minimum physical requirements for a particular use. Applications must therefore be considered within requirements of building codes and other characteristics of the end use.

\section{Industrial, Nonresidential, and Other Uses}

The uses in the industrial market that were considered in this study are van interiors, boxes and crates, pallets, and air cargo containers-the total of which represents approximately $25 \%$ of the industrial market. However, there are many diverse end uses for softwood plywood in the industrial market, each requiring a unique set of physical properties. Unlike requirements for the residential construction market, characteristics other than strength and stiffness are important in many industrial uses of softwood plywood. For example, the weight of the material from which a container is made can be more significant than the material strength. Ponderosa pine could have an advantage over some other species used in plywood because of its combination of moderate strength and light weight. Because many uses in the industrial market require a face veneer of $\mathrm{A}$ or $\mathrm{B}$ grade, some Black Hills ponderosa pine plywood could fit these requirements.

The nonresidential construction market uses plywood in many ways, such as concrete forms and temporary structures.

Homeowner and miscellaneous uses would cover applications ranging from home remodeling to furniture. For structural use, ponderosa pine plywood would be subject to conditions similar to residential construction.

\section{MARKETING BLACK HILLS PLYWOOD}

\section{Production and Demand in Relation to Geography}

The distribution of plywood plants in the United States is shown in table 3. Plywood production in the South has risen dramatically since the first plant was established there in 1964. The number of plants has increased in the South and decreased in the Northwest. Although production capacity figures for some states and individual plants are available in the trade literature, estimates of total industry plant capacity from 1970 to 1978 are less certain. It is expected, however, that most future industry growth will occur in the South.

Relative volumes of plywood shipped from each producing region to various Rand McNally Major Trading Areas (Rand McNally and Company 1963) offer some insight into comparative advantages each region may have.

Shipment data on sheathing plywood for 1976 (American Plywood Association 1977b) indicate that shipments from producers in the South went to all but seven of 52 Rand McNally Major Trading Areas (including Alaska, Honolulu, and Export); shipments from producers in the West went to all Major Trading Areas; shipments from the producers Inland went to all but three Major Trading Areas (table 4). The regional pattern of shipments from the South is most apparent, while shipments from the West and Inland Regions appear to be more widely distributed.

Within the range of sheathing grades produced, certain producing regions manufacture a disproportionately large share of certain grades (table 5). The Inland Region, for example, shipped slightly less than $18 \%$ of the industry's sheathing production in 1976. However, of the total C-D Interior sheathing produced, the Inland 
Table 2.-Softwood plywood applications by grade in major end use market segments ${ }^{1}$

\begin{tabular}{|c|c|c|c|c|c|c|c|c|c|c|c|c|c|c|c|c|c|}
\hline & \multirow{2}{*}{$\begin{array}{c}\text { Panel } \\
\text { use }^{2}\end{array}$} & \multicolumn{5}{|c|}{ Residential } & \multirow{2}{*}{\multicolumn{3}{|c|}{ 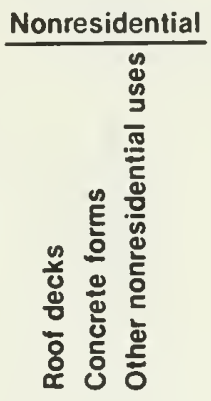 }} & \multicolumn{4}{|c|}{ Industrial } & \multicolumn{2}{|c|}{ Distribution $^{3}$} & \multicolumn{2}{|c|}{ Miscellaneous $^{3}$} \\
\hline & & 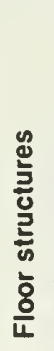 & 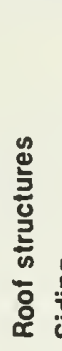 & og & 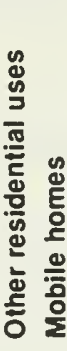 & 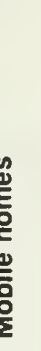 & & & & 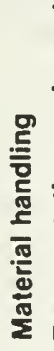 & 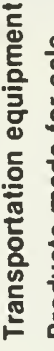 & 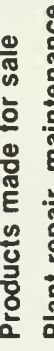 & 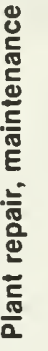 & 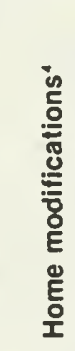 & 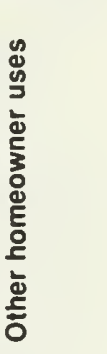 & 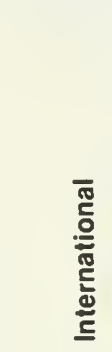 & 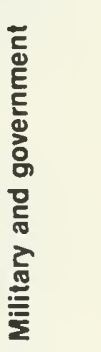 \\
\hline \multicolumn{18}{|l|}{ Engineered grades: } \\
\hline C-D, C-D.X & 1 & $x$ & $x$ & & $x>$ & $x$ & $x$ & $x>$ & $x$ & $x$ & $x$ & $x>$ & $x$ & $x$ & & $x$ & $x$ \\
\hline Structural I C-D & 1 & & & & & $x$ & $x$ & & & & $x$ & & $x$ & & & & \\
\hline Structural II C-D & 1 & & & & & & & & & & $x$ & & $x$ & & & & \\
\hline Underlayment & 1 & $x$ & & & $x>$ & $x$ & & & $x$ & & & & $x$ & $x$ & & $x$ & \\
\hline T\&G Underlayment ${ }^{5}$ & 1 & $x$ & & & & & & & & & & & $\bar{x}$ & $\bar{x}$ & & $x$ & \\
\hline $2-4-1$ & 1 & $x$ & & & $x$ & & $x$ & & $x$ & & & & $x$ & & & & \\
\hline C-D Plugged & I & & & & & & & & & & & & $x$ & & & & \\
\hline $\mathrm{C}-\mathrm{C}$ & $\mathrm{E}$ & & & & & & & & $x$ & $\mathrm{x}$ & $x$ & & $x$ & & & $\mathrm{x}$ & \\
\hline Underlayment C-C Plugged & $E$ & $x$ & & & & & & & & & & & $\mathrm{X}$ & $\bar{x}$ & & $x$ & \\
\hline C-C Plugged & $E$ & & $x$ & $x$ & & & $x$ & $x>$ & $x$ & & & & $x$ & & & & \\
\hline Structural I C.C & $E$ & & & & & $x$ & $x$ & & & & $x$ & & $\mathrm{x}$ & & & & \\
\hline B-B Plyform I \& II & E & & & & & & & $x$ & & & & & $x$ & & & & \\
\hline \multicolumn{18}{|l|}{ Appearance grades: } \\
\hline$N \cdot N, N-A, N \cdot B$ & 1 & & & & & & & & & & $x$ & & $\mathrm{x}$ & & $\mathrm{x}$ & & \\
\hline$N-D$ & 1 & & & & & & & & & & $x$ & & $x$ & & $x$ & & \\
\hline A-A & 1 & & & & & & & & & & $x$ & & $x$ & & $x$ & & \\
\hline$A \cdot B$ & 1 & & & & & & & & & & $x$ & & $x$ & & $x$ & & \\
\hline A-D & 1 & & & & $x>$ & $\bar{x}$ & & & & $\bar{x}$ & $x$ & $x>$ & $x$ & $x$ & $\mathrm{X}$ & & $\mathrm{X}$ \\
\hline B-B & 1 & & & & & & & & & & $x$ & & $x$ & & $x$ & & \\
\hline B-D & 1 & & & & & & & & & & $x$ & & $x$ & & $x$ & & \\
\hline$A \cdot A$ & $E$ & & & & & & & & & & $x$ & & $x$ & & $x$ & & \\
\hline$A-B$ & $E$ & & & & & & & & & & $x$ & & $x$ & & $x$ & & \\
\hline$A-C$ & $E$ & & $x$ & $x$ & $x>$ & $x$ & & & $x$ & $x$ & $x$ & X & $x$ & & $x$ & $x$ & $x$ \\
\hline B-B & $E$ & & & & & & & & & & $x$ & & $x$ & & $x$ & & \\
\hline$B-C$ & $E$ & & $x$ & $X$ & $x$ & & $x$ & $\mathrm{x}$ & $x$ & $X$ & $\mathrm{x}$ & $\times$ & $x$ & $x$ & $x$ & $x$ & $x$ \\
\hline
\end{tabular}

\footnotetext{
Specialty grades:
}

\begin{tabular}{|c|c|c|c|c|c|c|c|c|c|}
\hline Decorative panels & 1 & & $x$ & & & & $\mathrm{X}$ & & \\
\hline Plyron & 1 & & $x$ & & & & $x$ & & \\
\hline HDO & $E$ & & & $x$ & & $x$ & $x$ & & \\
\hline MDO & $E$ & $x \times$ & $x$ & $x$ & $\mathrm{x}$ & $\mathrm{x}$ & $\mathrm{x}$ & $\mathrm{x}$ & \\
\hline 303 siding, T 1-11 & $E$ & $x \times$ & $\times x$ & $x$ & & $x$ & $x$ & $x$ & $x \times$ \\
\hline Plyron & $E$ & & & & & & $x$ & & \\
\hline Marine & $E$ & & & & $x$ & $x$ & $x$ & & \\
\hline
\end{tabular}

'Sources: Anderson (1977), American Plywood Association (1976).

'Panel use: $I=$ Interior, $E=$ Exterior.

${ }^{3}$ Distribution is also called the homeowner market. For both Distribution and Miscellaneous market segments, almost all grades are in demand; only the principal grades are indicated.

"Includes home repairs, additions, alterations.

${ }^{3} T \& G=$ Tongue and Groove. 


\begin{tabular}{|c|c|c|c|c|c|}
\hline Area & 1970 & 1974 & 1976 & 1977 & 1978 \\
\hline \multicolumn{6}{|l|}{ South and Southeast } \\
\hline Alabama & 3 & 7 & 8 & 8 & 9 \\
\hline Arkansas & 6 & 8 & 8 & 8 & 9 \\
\hline Florida & 1 & 2 & 1 & - & - \\
\hline Georgia & 5 & 5 & 7 & 5 & 6 \\
\hline Louisiana & 10 & 11 & 13 & 13 & 13 \\
\hline Maryland & 1 & 1 & 1 & 1 & 1 \\
\hline Mississippi & 5 & 6 & 6 & 5 & 6 \\
\hline North Carolina & 5 & 5 & 5 & 6 & 8 \\
\hline Oklahoma & - & 1 & 1 & 1 & 1 \\
\hline South Carolina & 1 & 2 & 2 & 3 & 4 \\
\hline Texas & 7 & 7 & 9 & 7 & 9 \\
\hline Virginia & 2 & 1 & 2 & 2 & 2 \\
\hline Total & 46 & 56 & 63 & 59 & 68 \\
\hline \multicolumn{6}{|l|}{ Pacific Northwest and Coast } \\
\hline California & 16 & 17 & 23 & 16 & 13 \\
\hline Oregon & 84 & 79 & 85 & 79 & 69 \\
\hline Washington & 32 & 28 & 28 & 25 & 27 \\
\hline Total & 132 & 124 & 136 & 120 & 109 \\
\hline \multicolumn{6}{|l|}{ Inland } \\
\hline Idaho & 5 & 4 & 5 & 5 & 5 \\
\hline Montana & 5 & 5 & 7 & 6 & 5 \\
\hline Total & 10 & 9 & 12 & 11 & 10 \\
\hline Other States ${ }^{2}$ & 4 & 3 & 4 & 2 & 2 \\
\hline Total U.S. & 192 & 192 & 215 & 192 & 189 \\
\hline Total Canada & 28 & 30 & 28 & 28 & 33 \\
\hline TOTAL NORTH AMERICA & 220 & 222 & 243 & 220 & 222 \\
\hline
\end{tabular}

\footnotetext{
'Source: Directory of the Forest Products Indusiry for each year, published by Miller Freeman Publications, Inc., San Francisco, Calit.

${ }^{2}$ Number of softwood plywood plants in states not typically associated with any of the three recognized producing regions.
}

Region shipped almost $96 \%$, and of the total C-C Plugged Exterior sheathing produced, the Inland Region shipped almost $43 \%$.

\section{Freight Rates}

Freight rates are a large factor in delivered price and, given a commodity type product like sheathing, can often determine where plywood is purchased. There are numerous market areas where a Black Hills producer might ship plywood with a freight advantage, or at least with a freight parity, compared to existing production centers.

Current freight regulations require plywood producers to separate the f.o.b. mill price from freight charges and permit customers to pay freight costs on the basis of actual weights. Consequently, ponderosa pine plywood, would have significant freight cost advantage over Douglas-fir or southern pine plywood due to its lighter weight.
Newcastle, Wyo., and Rapid City and Whitewood, S. Dak., were selected as representative Black Hills locations on which to base freight rate computations in this study. Of all other southern and western rail shipping points considered, one or more of the three Black Hills locations have the lowest rates to the following cities: Denver, Des Moines, Kansas City, Milwaukee, Minneapolis, Omaha, and Wichita. Freight rates to Chicago from the Black Hills locations were slightly higher than the lowest rate from the South, but remained competitive.

Of all truck shipping points considered, one or more of the three Black Hills locations have the lowest rates to the following cities: Chicago, Denver, Des Moines, Kansas City, Minneapolis, Omaha, and Wichita.

Table 7 shows how these truck and rail rates compare. In almost all cases, truck rates are highly competitive with rail; in a few instances they are lower. With the exception of Rapid City and Whitewood to Wichita and of Newcastle to Omaha, rail transport is less than $\$ 2.00$ cheaper than truck transport. For 
Table 4.-Shipments to major trade areas receiving $1 \%$ or more of total production from each producing region'

\begin{tabular}{|c|c|c|c|c|c|c|c|c|}
\hline \multicolumn{3}{|c|}{ Southern } & \multicolumn{3}{|c|}{ Inland } & \multicolumn{3}{|c|}{ Western } \\
\hline $\begin{array}{l}\text { Trade area } \\
\text { destination }\end{array}$ & $\begin{array}{l}\text { Amount } \\
\text { shipped }^{2}\end{array}$ & $\begin{array}{l}\text { Percent of } \\
\text { production } \\
\text { from region }\end{array}$ & $\begin{array}{l}\text { Trade area } \\
\text { destination }\end{array}$ & $\begin{array}{l}\text { Amount } \\
\text { shipped }^{2}\end{array}$ & $\begin{array}{l}\text { Percent of } \\
\text { production } \\
\text { from region }\end{array}$ & $\begin{array}{l}\text { Trade area } \\
\text { destination }\end{array}$ & $\begin{array}{l}\text { Amount } \\
\text { shipped }^{2}\end{array}$ & $\begin{array}{l}\text { Percent of } \\
\text { production } \\
\text { from region }\end{array}$ \\
\hline Charlotte & 486,665 & 9.03 & Spokane & 185,318 & 9.85 & San Francisco/ & & \\
\hline Atlantal & & & Salt Lake City & 176,869 & 9.40 & Oakland & 505,237 & 14.80 \\
\hline Chattanooga & 334,102 & 6.20 & Denver & 151,156 & 8.03 & Portland & 493,472 & 14.45 \\
\hline Chicago & 293,543 & 5.45 & New York & 131,522 & 6.99 & Los Angeles & 482,389 & 14.13 \\
\hline Dallas/ & & & Minneapolis/ & & & Seattle & 306,435 & 8.98 \\
\hline Fort Worth & 289,767 & 5.38 & St. Paul & 127,871 & 6.79 & Export & 247,908 & 7.26 \\
\hline Memphis & 238,737 & 4.43 & Seattle & 115,410 & 6.13 & New York & 201,433 & 5.90 \\
\hline Houston & 234,824 & 4.36 & San Franciscol & & & Chicago & 127,535 & 3.74 \\
\hline Detroit/ & & & Oakland & 104,011 & 5.53 & Boston/ & & \\
\hline Toledo & 229,093 & 4.25 & Boston! & & & Providence & 124,209 & 3.64 \\
\hline New York & 203,471 & 3.78 & Providence & 76,779 & 4.08 & Phoenix & 103,941 & 3.04 \\
\hline $\begin{array}{l}\text { Richmond/ } \\
\text { Norfolk }\end{array}$ & & & Milwaukee & 71,793 & 3.81 & Minneapolis/ & & \\
\hline Philadelphia & $\begin{array}{l}198,767 \\
195,488\end{array}$ & 3.69 & Export & 65,978 & 3.51 & St. Paul & 102,751 & 3.01 \\
\hline New Orleans & $\begin{array}{l}195,488 \\
163,130\end{array}$ & 3.63 & Detroit/ & & & Salt Lake City & 86,199 & 2.52 \\
\hline Washington/ & & 3.03 & $\begin{array}{l}\text { Toledo } \\
\text { Philadelphia }\end{array}$ & $\begin{array}{l}64,832 \\
63,046\end{array}$ & $\begin{array}{l}3.44 \\
3.35\end{array}$ & $\begin{array}{l}\text { Milwaukee } \\
\text { Philadelphia }\end{array}$ & $\begin{array}{l}76,331 \\
70,043\end{array}$ & $\begin{array}{l}2.24 \\
2.05\end{array}$ \\
\hline Baltimore & 153,333 & 2.85 & Los Angeles & 62,378 & 3.31 & Detroit/ & & \\
\hline St. Louis & 149,583 & 2.78 & Portland & 51,952 & 2.76 & Toledo & 54,635 & 1.60 \\
\hline Miami & 143,574 & 2.66 & Des Moines/ & & & Denver & 51,843 & 1.52 \\
\hline Jacksonville & 123,056 & 2.28 & Sioux City & 34,627 & 1.84 & Washington/ & & \\
\hline Birmingham & 118,499 & 2.20 & Washington/ & & & Baltimore & 47,538 & 1.34 \\
\hline Kansas City & 111,850 & 2.08 & Baltimore & 30,807 & 1.64 & Kansas City & 42,759 & 1.25 \\
\hline Cleveland & 110,724 & 2.05 & St. Louis & 29,804 & 1.58 & Spokane & 42,447 & 1.24 \\
\hline Milwaukee & 110,320 & 2.05 & Buffalol & & & Des Moines/ & & \\
\hline Pittsburgh & 105,464 & 1.96 & Rochester & 26,391 & 1.40 & Sioux City & 36,403 & 1.07 \\
\hline Little Rock & 104,171 & 1.93 & Kansas City & 20,543 & 1.09 & & & \\
\hline Knoxville & 95,807 & 1.78 & Omaha & 19,635 & 1.04 & & & \\
\hline San Antonio & 94,103 & 1.76 & & & & & & \\
\hline $\begin{array}{l}\text { Indianapolis } \\
\text { Tampal }\end{array}$ & 89,924 & 1.76 & & & & & & \\
\hline St. Petersburg & 84,574 & 1.57 & & & & & & \\
\hline Cincinnati/ & & & & & & & & \\
\hline Dayton & 83,974 & 1.56 & & & & & & \\
\hline Boston/ & & & & & & & & \\
\hline Providence & 79,752 & 1.48 & & & & & & \\
\hline Des Moines/ & & & & & & & & \\
\hline Sioux City & 68,994 & 1.28 & & & & & & \\
\hline Nashville & 63,832 & 1.18 & & & & & & \\
\hline Shreveport & 58,641 & 1.09 & & & & & & \\
\hline Oklahoma City & 57,110 & 1.06 & & & & & & \\
\hline Columbus & 53,622 & 1.00 & & & & & & \\
\hline
\end{tabular}

'Data Source: American Plywood Association (1977b).

${ }^{2}$ In thousand square feef $\left(M \mathrm{ft}^{2}\right)$, 3/8-inch basis.

customers not located on rail sidings, any surcharge added to rail rates to cover truck delivery would likely overcome the slight cost advantage of rail shipment.

In the period since these figures were originally compiled (1977), several across-the-board, percentage freight rate increases have increased the rate advantage of Black Hills locations, compared to the Pacific Northwest and Southern Regions, when shipping to the Great Lakes States.

\section{Market Potentials}

Based on freight costs and trade patterns, the trade areas represented by the cities listed in table 7 probably comprise the prime potential market for a poten- tial Black Hills plywood producer. Data for 1976, assembled in table 8, support the concept that plywood manufactured in the Black Hills can be marketed successfully in northern and central Great Plains, the upper Midwest, and the Great Lakes area.

\section{Rough Grades}

The total industry column in table 8 shows the proportion of total industry production of sheathing grades that was shipped to the prime Black Hills market area. For example, the total volume of sheathing that was shipped to the prime market area is about 1.75 $\mathrm{MMM} \mathrm{ft}^{2}$, 3/8-inch basis. This volume is about $16 \%$ of sheathing production of the entire plywood industry. 
Table 5.-Distribution of 1976 sheathing plywood shipments by grade and producing region'

\begin{tabular}{|c|c|c|c|c|}
\hline \multirow{2}{*}{$\begin{array}{l}\text { Sheathing } \\
\text { plywood } \\
\text { grade or } \\
\text { group }\end{array}$} & \multirow{2}{*}{$\begin{array}{c}\text { Industry } \\
\text { lotal } \\
\text { production }\end{array}$} & \multicolumn{3}{|c|}{$\begin{array}{l}\text { Percent of shipments } \\
\text { from each region }\end{array}$} \\
\hline & & Inland & Southern & Western \\
\hline \multicolumn{5}{|l|}{ Interior } \\
\hline $\begin{array}{l}\text { C-D } \\
\text { C-D-X }\end{array}$ & $\begin{array}{r}56,161 \\
7,350,432\end{array}$ & $\begin{array}{l}95.71 \\
15.64\end{array}$ & $\begin{array}{r}0.47 \\
55.54\end{array}$ & $\begin{array}{r}3.82 \\
28.83\end{array}$ \\
\hline Structural I \& II & 157,380 & 7.88 & 0.81 & 91.31 \\
\hline C-D Plugged & 1,132 & 8.83 & 13.62 & 77.55 \\
\hline C.D-X Plugged & 368,621 & 14.14 & 42.24 & 43.62 \\
\hline Underlayment & 324 & 45.18 & $\ldots$ & 54.82 \\
\hline Underlayment Exterior glue & $1,226,010$ & 22.35 & 48.82 & 28.83 \\
\hline $2-4-1$ & 4,750 & 0.23 & -- & 99.77 \\
\hline $2 \cdot 4-1-x$ & 106,023 & 31.05 & 3.53 & 65.41 \\
\hline Miscellaneous & 41,621 & 56.62 & 3.19 & 40.19 \\
\hline Total Interior & $9,312,454$ & 17.16 & 52.01 & 30.83 \\
\hline \multicolumn{5}{|l|}{ Exterior } \\
\hline C-C & 109,978 & 29.15 & 16.94 & 53.91 \\
\hline C.C Plugged & 201,193 & 42.70 & 3.89 & 53.41 \\
\hline Total Exterior & 311,172 & 37.91 & 8.50 & 53.48 \\
\hline Mill stamp & 633,120 & 18.23 & 40.09 & 41.69 \\
\hline Rejects & 397,876 & 11.31 & 63.55 & 25.13 \\
\hline TOTAL SHEATHING & $10,684,622$ & 17.62 & 50.43 & 31.95 \\
\hline
\end{tabular}

'Data source: American Plywood Association (1977b).

${ }^{2}$ In thousand square feet $\left(M \mathrm{ft}^{2}\right), 3 / 8$-inch basis.

Table 6. - Weight (pounds per $\mathrm{M} \mathrm{ft}{ }^{2}$, surface area basis) for selected species, thicknesses, and constructions of sheathing plywood panels'

\begin{tabular}{lcccccc}
\hline $\begin{array}{c}\text { Nominal } \\
\text { thickness }\end{array}$ & $\begin{array}{c}\text { Number of double } \\
\text { glue lines, } \\
\text { typical panel } \\
\text { construction }\end{array}$ & $\begin{array}{c}\text { Douglas-fir } \\
\text { Coast }\end{array}$ & $\begin{array}{c}\text { Douglas-fir } \\
\text { Interior } \\
\text { North }\end{array}$ & $\begin{array}{c}\text { Western } \\
\text { larch }\end{array}$ & $\begin{array}{c}\text { Southern pine } \\
\text { Loblolly/ } \\
\text { Shortleaf }\end{array}$ & $\begin{array}{c}\text { Longleafl } \\
\text { Slash }\end{array}$ \\
\hline $5 / 16$ & 1.0 & 928 & 918 & 997 & 966 & 1,103 \\
$3 / 8$ & 1.0 & 1,105 & 1,093 & 1,188 & 1,151 & 1,315 \\
$1 / 2,3$ ply & 1.0 & 1,459 & 1,443 & 1,569 & 1,521 & 1,739 \\
$1 / 2,4$ ply' & 1.5 & 1,480 & 1,465 & 1,590 & 1,542 & 1,761 \\
$1 / 2,5$ ply & 2.0 & 1,501 & 1,486 & 1,612 & 1,563 & 1,782 \\
$5 / 8$ & 2.0 & 1,855 & 1,836 & 1,993 & 1,933 & 2,207 \\
$3 / 4$ & 2.0 & 2,209 & 2,186 & 2,375 & 2,302 & 2,631 \\
& & & & & & 1,260 \\
\hline
\end{tabular}

'Computed using wood density figures at $12 \%$ moisture (USDA Forest Products Laboratory 1974) and glue weight of $60 \mathrm{lb} / \mathrm{M} \mathrm{ft} \mathrm{t}^{2}$ of double glue line. Glue assumed to have $5 / 6$ resin component with $65 \%$ solids and $1 / 6$ hardener. Dried glue weight is $42.5 \mathrm{lb} / \mathrm{M} \mathrm{ft}^{2}$ of double glue line.

${ }^{2}$ From American Plywood Association (1974). 
Table 7.-Freight rates' (dollars per $M \mathrm{ft}^{2}$ ) for $1 / 2$-inch, 4-ply sheathing from Black Hills points of origin to selected destinations representative of market trade areas (Rand McNally and Company 1963)

\begin{tabular}{|c|c|c|c|c|c|c|}
\hline \multirow[t]{2}{*}{ Destinations } & \multicolumn{2}{|c|}{ Rapid City, S. Dak. } & \multicolumn{2}{|c|}{ Whitewood, S. Dak. } & \multicolumn{2}{|c|}{ Newcastle, Wyo. } \\
\hline & Truck & Rail & Truck & Rail & Truck & Rail \\
\hline Chicago $^{2}$ & 19.08 & 17.22 & 20.07 & 17.72 & 18.71 & 18.21 \\
\hline Denver & 10.53 & 9.66 & 10.53 & 10.66 & 8.80 & 9.29 \\
\hline Des Moines & 14.12 & 12.02 & 14.99 & 13.51 & 14.99 & 14.99 \\
\hline Kansas City & 15.49 & 14.99 & 15.86 & 15.49 & 16.48 & 14.99 \\
\hline Minneapolis & 14.00 & 12.02 & 14.00 & 12.51 & 14.74 & 15.36 \\
\hline Omaha & 12.64 & 11.15 & 13.75 & 11.77 & 14.00 & 11.77 \\
\hline Wichita $^{3}$ & 16.35 & 11.52 & 15.49 & 11.89 & 15.49 & 14.99 \\
\hline Milwaukee & - & 16.97 & - & 17.35 & - & 17.97 \\
\hline
\end{tabular}

\footnotetext{
'Commodity rate for truck and rail transport, 1977 prices.

${ }^{2}$ Only one rail rate to Chicago lower than those shown was identified, $\$ 16.44$ from Birmingham, Ala.

${ }^{3}$ Diboll, Tex., had a lower rail rate of $\$ 15.21$ to Wichita.

"For comparison, Birmingham, Ala. had a rate of $\$ 17.97$ to Milwaukee, equivalent to that for Newcastle, Wyo.
}

Table 8 also shows the proportion of total industry production shipped to the prime market area from each major plywood region. For example, the Western and Southern Regions each shipped just under $14 \%$ of their total production to the prime market area in 1976. However, the Inland Region shipped about $29 \%$ of its production to the same trade areas. This relationship could be expected from comparing relative freight costs between regions.

Within each grade listed in table 8 , the proportion shipped from each producing region reflects both freight cost influences and preferences in consuming regions for certain plywood types based on species or other wood characteristics. For example, of the total Underlayment volume shipped to the prime market area, the Inland Region supplied about $35 \%$, the Southern Region about $47 \%$, and the Western Region about $18 \%$. Table 8 further indicates that several grades which could be produced in the Black Hills would have a good chance of market success in the eight trade areas of the prime market area. For example, plywood from Black Hills ponderosa pine could be manufactured in C-C, C-D, C-C Plugged, C-D Plugged, Underlayment, and 2-4-1 grades, with either interior or exterior glue. Even allowing for APA species group differences, ponderosa pine plywood in these grades would probably be acceptable.

\section{Siding}

Siding panels currently are manufactured from plywood species groups 1 through 4 . As shown in table 8, the prime market area in 1976 received slightly less than $15 \%$ of all siding manufactured under the American Plywood Association's specifications for 303 siding products. Table 8 also shows that about $25 \%$ of siding made from species groups 2, 3, and 4 was shipped to the prime market area. Of this volume, virtually all (99.85\%) 303 siding originated in the Western Region. Of the minute amount produced in the Inland Region, most $(96 \%)$ was shipped to the prime market area.

Recently, the American Plywood Association revised its specifications for 303 siding (see appendix). Given the diversity of classes and grades defined in the new APA specifications, $C$ grade veneer in the Black Hills could have increased technical potential for utilization in siding panels. Also, the prime market area for the Black Hills appears to accept enough 303 siding of all species groups for a market to be established for modest quantities of siding manufactured from Black Hills ponderosa pine.

\section{TIMBER RESOURCES AND PLYWOOD}

The Black Hills area is about 20,600 square miles of forested mountains located along the boundary between western South Dakota and northeastern Wyoming (U.S. Department of Agriculture and U.S. Department of Interior 1967). Surrounded by short grass prairie for at least 100 miles in all directions, the Black Hills is a uniquely isolated mix of federal, state, and private land (fig. 2). State land is largely concentrated in Custer State Park, located in the southeastern part of the Black Hills. Private land is scattered throughout the federal land, usually in small tracts.

To evaluate any proposed forest products venture, such as a plywood plant in the Black Hills, it is necessary to estimate the amount of timber required. Further, it is important to know how much material is available, what part of this material is used currently, and what part is suitable for the proposed product. 


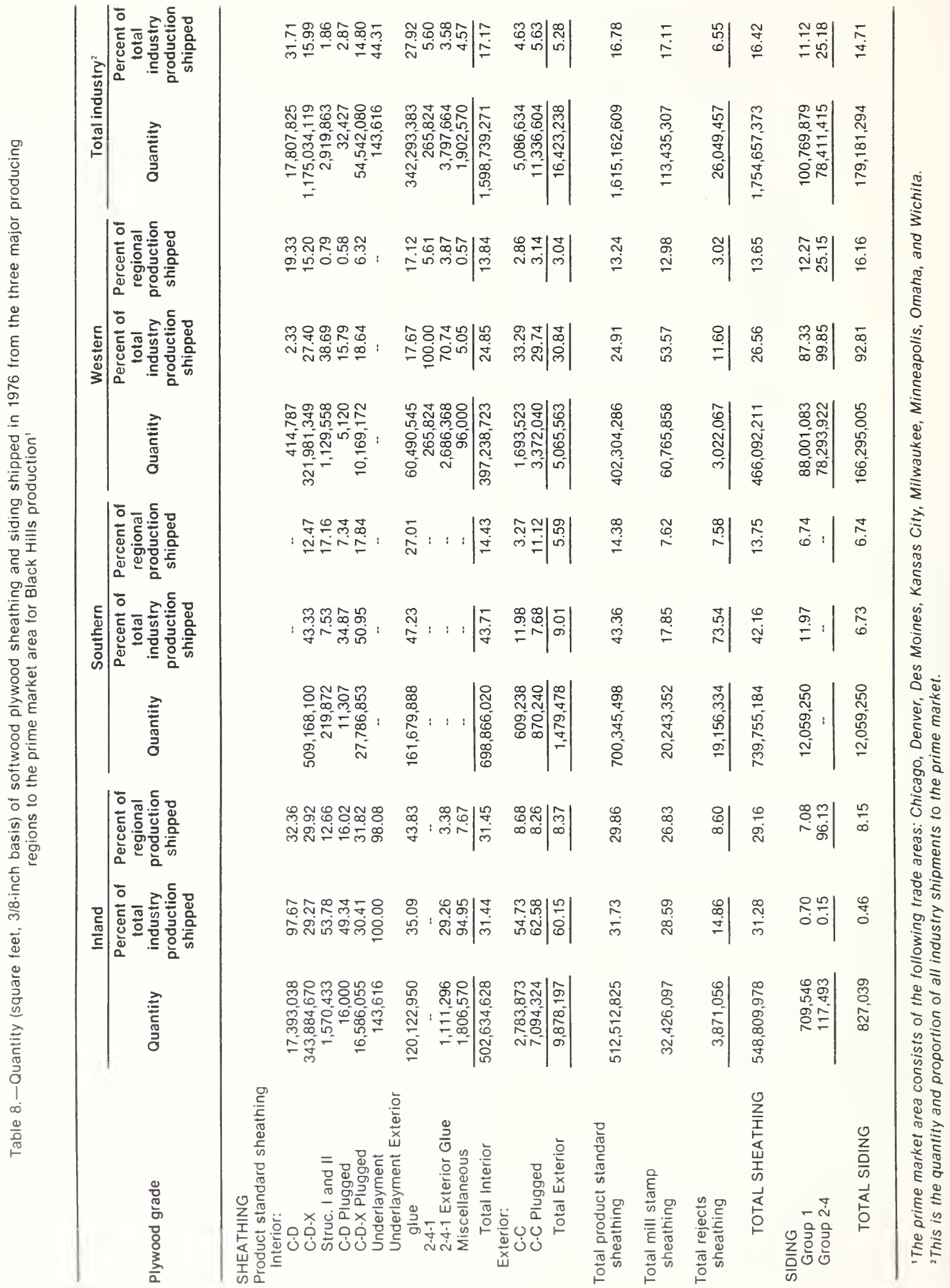




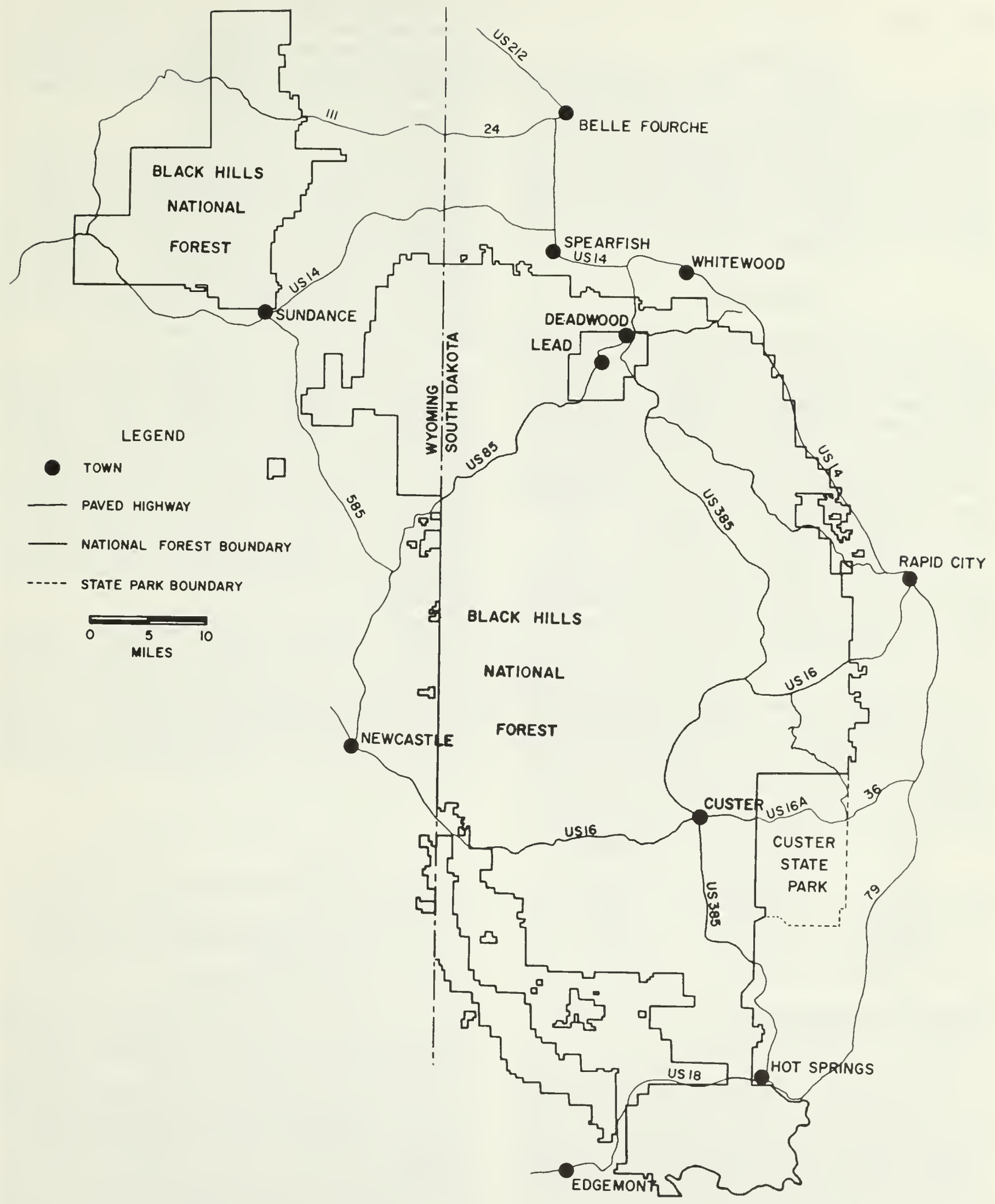

Figure 2.-Black Hills National Forest and adjacent area. 


\section{THE FOREST RESOURCE}

\section{Land}

Total forest land area in all ownerships is about 2.1 million acres, and of this area, 1.9 million acres (88\%) are classified as productive nonreserved forest land. ${ }^{9}$ Of this productive nonreserved forest land, 1.1 million acres are in the Black Hills NF, 627,000 acres are in private ownership, and 131,000 acres are administered by state agencies and federal agencies other than USDA Forest Service.

\section{Growing Stock}

Ponderosa pine is the predominant species in the Black Hills, with minor amounts of white spruce (Picea glauca), aspen (Populus tremuloides), and other hardwoods present. Table 9 shows the distribution of growing stock among areas and timber types. Ponderosa pine is the only species considered in this study. Any small volumes of spruce harvested with pine would likely be processed for plywood with pine or sold for sawlogs. Major harvests of aspen are not planned, although small amounts may occasionally become available.

The Black Hills NF contains about $68 \%$ of the growing stock volume; private owners, 25\%; and other public agencies, $7 \%$. Sawlog volume in the Black Hills $\mathrm{NF}$ is also $68 \%$ of the total, with $27 \%$ on private lands and $5 \%$ in other holdings.

Nearly two-thirds of the ponderosa pine growing stock in diameter classes 5 inches d.b.h. and greater, on the Black Hills NF, have diameters between 5.0 and 8.9 inches. However, these diameter classes contain only about $22 \%$ of the net cubic foot volume. About half the cubic foot volume is in diameter classes from 9.0 to 14.9 inches. The complete distribution ${ }^{10}$ is as follows:

$\begin{array}{ccc}\text { D.b.h. } & \text { Live stems } & \text { Net volume } \\ \text { inches } & \text { percent } & \text { percent } \\ 5.0-8.9 & 65.2 & 21.9 \\ 9.0-14.9 & 29.9 & 49.6 \\ 15.0-20.9 & 4.5 & 23.9 \\ 21.0+ & 0.4 & 4.6\end{array}$

\section{RESOURCES FOR PLYWOOD}

\section{Current Utilization}

Sawmills are now the primary users of logs 8 inches d.b.h. and larger. A small volume (about 4\%) of

'Productive nonreserved forest land is defined as forest land capable of producing industrial wood crops. This requires a minimum growth rate of 20 cubic feet per acre per year, and the land must not be withdrawn from timber utilization because of statute or administrative regulation.

${ }^{10}$ These figures are based on data from computer program GROW that was used as part of the timber management process. The data were supplied by the Black Hills National Forest. sawtimber size material is used for commercial poles (Setzer and Barrett 1977). Many sawmills are now equipped to saw logs smaller than those previously classified as sawlog size material. Sawmill output in the Black Hills is currently about $80 \%$ board lumber and about $20 \%$ dimension lumber. ${ }^{11}$

Estimated future sawmill requirements for sawtimber are based on past experience. Mill capacity figures are based on directories for the forest products industry in South Dakota and Wyoming (South Dakota Department of Game, Fish and Parks 1974, Wyoming Department of Economic Planning and Development 1974), as updated by unpublished data. ${ }^{12}$ Based primarily on 1-shift operation, the estimated sawmill capacity in the Black Hills as of early 1978 was 200 million board feet lumber tally (MM fbm (LT)).

For a variety of reasons, sawmill production has been less in the past than suggested by the estimated capacity figures. Table 10 shows an effective capacity figure that estimates the degree to which sawmills have used their total capacity in utilizing the timber actually cut. The underutilization of production capacity indicated in table 10, together with the general lumber market conditions from 1972 to 1975 , imply that in relatively poor years, production averaged only about $60-70 \%$ of total capacity. Effective capacity of $82 \%$ in 1974 indicates a relatively good year for Black Hills lumber producers.

Figures in table 10 suggest that a $75 \%$ effective capacity is a reasonable estimate of sawmill utilization for purposes of this analysis. Then, assuming a recovery factor ${ }^{13}$ of 1.3 , based on present USDA Forest Service Appraisal Guidelines, and assuming that these figures will hold for the next 10 years, the estimated log supply required to sustain sawmills at an average production level during this period is as follows:

$\begin{aligned} & \begin{array}{c}\text { MM fbm lumber tally current total } \\ \text { capacity } \\ \times 0.75 \\ \text { effective capacity proportion of total } \\ \text { capacity }\end{array} \\ &=150 \quad \text { MM fbm lumber tally effective capacity } \\ & \div 1.3 \quad \begin{array}{l}\text { MM fbm lumber tally/MM fbm log scale } \\ \text { recovery factor }\end{array} \\ &=115.4 \text { MM fbm net log scale }\end{aligned}$

Thus, the current estimated average annual sawmill requirement for timber is about $115 \mathrm{MM} \mathrm{fbm}$ (LS).

\footnotetext{
"Personal communication from F. P. Smedley, USDA Forest Service, Black Hills NF, Custer, S. Dak. (On file at Rocky Mountain Forest and Range Experiment Station, Fort Collins, Colo.)

'2Report of Black Hills Industry Mix Task Force. 1974. Unpublished report on file at Rocky Mountain Forest and Range Experiment Station.

${ }^{13}$ Recovery factor is the lumber output measured in foot board measure lumber tally (fbm (LT)) divided by the net log volume measured in board feet Scribner Decimal C log scale (fbm (LS)). All log volumes are given as net rather than gross, unless otherwise noted.
} 
Table 9.-Total sawtimber and growing stock, Black Hills area, 1974

\begin{tabular}{lccccccc}
\hline & \multicolumn{2}{c}{ South Dakota } & \multicolumn{2}{c}{ Wyoming } & \multicolumn{2}{c}{ Black Hills total } \\
\cline { 2 - 7 } Forest type & Sawtimber & $\begin{array}{c}\text { Growing } \\
\text { stock }\end{array}$ & Sawtimber & $\begin{array}{c}\text { Growing } \\
\text { stock }\end{array}$ & Sawtimber & $\begin{array}{c}\text { Growing } \\
\text { stock }\end{array}$ \\
\hline & $M f b m(L S)$ & $M f t^{3}$ & $M f b m(L S)$ & $M f t^{3}$ & $M f b m(L S)$ & $M f t^{3}$ \\
Ponderosa pine & $5,212,922$ & $1,542,243$ & $2,141,742$ & 644,683 & $7,354,664$ & $2,186,926$ \\
White spruce & 230,173 & 50,357 & 55,533 & 12,436 & 285,706 & 62,793 \\
Hardwoods & 133,251 & 39,388 & 115,518 & 57,309 & 248,769 & 96,697 \\
\cline { 2 - 7 } Total & $5,576,346$ & $1,631,988$ & $2,312,793$ & 714,428 & $7,889,139$ & $2,346,416$ \\
\hline
\end{tabular}

Table 10.-Estimates of available timber compared with effective capacity of Black Hills sawmills

\begin{tabular}{|c|c|c|c|c|c|c|c|}
\hline Year & $\begin{array}{l}\text { NF total } \\
\text { cut } \\
\text { all size } \\
\text { classes }^{1}\end{array}$ & $\begin{array}{c}\text { NF total } \\
\text { cut } \\
\text { sawtimber }\end{array}$ & $\begin{array}{c}\text { All ownerships } \\
\text { total cut } \\
\text { sawtimber }\end{array}$ & $\begin{array}{c}\text { Mill } \\
\text { capacity } \\
\text { lumber tally }\end{array}$ & $\begin{array}{l}\text { Lumber } \\
\text { recovery } \\
\text { factor }^{5}\end{array}$ & $\begin{array}{c}\text { Mill } \\
\text { capacity, } \\
\text { Scribner } \\
\text { log scale }\end{array}$ & $\begin{array}{l}\text { Effective } \\
\text { capacity }^{7}\end{array}$ \\
\hline & \multicolumn{3}{|c|}{$M M t b m(L S)$} & $M M f b m(L T)$ & & $M M f b m$ (LS) & Percent \\
\hline $\begin{array}{l}1972 \\
1973\end{array}$ & $\begin{array}{l}96.969 \\
89.170\end{array}$ & $\begin{array}{l}66.414 \\
61.073\end{array}$ & $\begin{array}{l}88.552 \\
81.430\end{array}$ & $\begin{array}{l}152.1 \\
152.1\end{array}$ & $\begin{array}{l}1.20 \\
1.19\end{array}$ & $\begin{array}{l}127.8 \\
127.8\end{array}$ & $\begin{array}{l}69.3 \\
63.7\end{array}$ \\
\hline 1974 & 112.011 & 76.716 & 102.288 & 152.1 & 1.22 & 124.7 & 82.0 \\
\hline 1975 & 76.796 & 52.598 & 70.130 & 152.1 & 1.49 & 102.1 & 68.7 \\
\hline
\end{tabular}

\footnotetext{
'Source: Black Hills NF Timber Management Plan 1977-1986.

${ }^{2}$ Board foot volume in all size classes multiplied by a factor of 0.6849 , the proportion of sawtimber in 1974.

${ }^{3}$ Computed by dividing Black Hills NF sawtimber cut by 0.75 because this sawtimber was three-fourths of total cut.

"Source: Black Hills Task Force Report, 1974. In 1976, capacity increased by 30 MM fbm (LT), all in one mill.

${ }^{5}$ Source: USDA Forest Service, Rocky Mountain Region Appraisal Bulletins for the respective time periods.

${ }^{\circ}$ Computed by dividing lumber tally mill capacity by lumber recovery factor.

'Percentage of total sawmill capacity (net log scale-column 7) that was used in processing sawtimber from all ownerships (column 4).
}

\section{0-Year Future Supply, 1977-1986}

The Black Hills NF plans to treat annually about 39,600 acres of forest land with a variety of silvicultural cuts. Most of this acreage is in the Standard Component ${ }^{14}$ with the remainder in the Special Component. ${ }^{15}$

\footnotetext{
"Standard Component is the component of the regulated, suitable, forested land on which crops of industrial wood can be grown and harvested with adequate protection of the forest resources under the usual provisions of the timber sale contract. This area includes stands of immature trees or areas not yet accessible, but which will be in the normal course of events. This area is capable of producing timber crops that have a reasonable probability of use, given the accessibility and economic conditions projected for a 10-year plan period, even though portions of the area may not be developed during this period.

${ }^{15}$ Special Component is the component of the regulated, forested land that is recognized in the multiple use plan as needing specially designed treatment of the timber resource to achieve landscape or other key resource objectives. For example, these are areas where timber management activities are informally delayed pending multiple use planning studies and management decisions, travel and water influence zones, peripheral portions of developed sites, and developed recreation areas.
}

Harvest treatment in the Marginal Component ${ }^{16}$ is not planned for the current 10-year period.

Under the 1977-1986 National Forest Timber Management Plan, programmed annual sawtimber harvest will be about $118 \mathrm{MM}$ fbm (LS) from trees 8 inches d.b.h. or larger. ${ }^{17}$ Planned utilization limits are to a 6-inch top. Trees 9 inches d.b.h. and larger are considered suitable for plywood because they can supply

\footnotetext{
${ }^{16}$ Marginal Component is the component of the regulated, suitable, forested land that does not qualify as a standard or special components, primarily because of excessive development cost, low product values, or resource protection constraints. Included may be drainages requiring unusual logging techniques, such as helicopters, skyline logging systems; areas where harvesting is blocked until government constructed roads are in place; or areas supplying a particular product or particular species type not presently in demand. Also included is the backlog of nonstocked areas which would otherwise be classed as standard, but are in need of reforestation that cannot be accomplished with Knutson-Vandenberg funds.

${ }^{17} T i m b e r$ Management Plan, Black Hills National Forest. 1977. Unpublished document on file at Rocky Mountain Forest and Range Experiment Station or available from Supervisor's Office, Black Hills NF, Custer, S. Dak.
} 
an 8-inch d.i.b. small end veneer log. Volume scheduled to be cut in trees 9 inches d.b.h. and larger is about 110.7 MM fbm (LS).

Timber harvested from non-national forest lands in South Dakota contributes significant amounts of roundwood. Estimated annual allowable harvest from these lands is about 57,290 cunits, with sawtimber amounting to about 15.6 $\mathrm{MM} \mathrm{fbm} \mathrm{(LS).}{ }^{18}$ Volume figures for Wyoming show an annual allowable cut of $22 \mathrm{MM} \mathrm{fbm}$ (LS) on private and other public land (U.S. Department of Agriculture and U.S. Department of Interior 1967). Past experience suggests that in both South Dakota and Wyoming, about half the allowable cut from nonnational forest land will be harvested.

Timber available from state and private land in both states can be expected to range from a minimum of $19 \mathrm{MM} \mathrm{fbm}$ (LS), representing the historical level of actual cuts, to a maximum allowable cut of about $38 \mathrm{MM} \mathrm{fbm}$ (LS). These volumes in trees 9 inches d.b.h. and larger are an important potential resource in determining the timber volume available for plywood.

\section{Availability for Plywood}

A surplus sawtimber volume that may be available for plywood manufacture is estimated by deducting current sawtimber usage from total volumes that are available (table 11).

${ }^{18}$ Personal communication from South Dakota Department of Fish, Game, and Parks, Division of Forestry. Figures from timber management plan for the period 1974-1984.
Total estimated supply of sawtimber in the Black Hills available for forest products, is in a range of 137 to $156 \mathrm{MM}$ fbm (LS), depending on volume cut from state and private lands. The supply in the Black Hills NF is divided into two parts: volume in trees equal to or greater than 9 inches d.b.h., and volume in trees less than 9 inches d.b.h. The supply of sawtimber from state and private land is assumed to be in trees 9 inches d.b.h. and larger.

In the use section of table 11, Black Hills NF volume in trees less than 9 inches d.b.h. is subtracted from total supply, because it is assumed trees smaller than 9 inches d.b.h. would not be suitable for plywood manufacture. When this volume is subtracted from the estimated total sawmill demand of $115 \mathrm{MM}$ fbm (LS), the remaining $108 \mathrm{MM} \mathrm{fbm}$ (LS) of demand is in trees 9 inches d.b.h. and larger.

The 1977 sawmill usage of $108 \mathrm{MM}$ fbm (LS) in trees 9 inches d.b.h. and larger is subtracted from 130 and $149 \mathrm{MM}$ fbm (LS), respectively; so, the minimum volume available for plywood manufacture ranges from 22 to $41 \mathrm{MM} \mathrm{fbm}$ (LS). The computations shown are based on a relatively stable sawmill capacity and suggest that total wood volume available for plywood manufacture may not be as large as desirable. Any significant additions or reductions in total sawmill capacity would inversely alter the volume available for plywood manufacture.

Another factor that might further limit the availability of timber for plywood manufacture is the requirements of the Small Business Set Aside Program. ${ }^{11}$ For the 5-year period ending December 31,

Table 11.-Computation of timber volume (MM fbm (LS)) available for plywood'

\begin{tabular}{|c|c|c|}
\hline & Expected & Maximum \\
\hline \multicolumn{3}{|l|}{ Supply of sawtimber } \\
\hline \multicolumn{3}{|l|}{ USDA Forest Service } \\
\hline$\geqslant 9$ inches & 111 & 111 \\
\hline$<9$ inches & +7 & +7 \\
\hline $\begin{array}{l}\text { Total Forest Service } \\
\text { State and private }\end{array}$ & $\begin{array}{r}118 \\
+19 \\
\end{array}$ & $\begin{array}{r}118 \\
+38 \\
\end{array}$ \\
\hline Total, all ownerships & 137 & 156 \\
\hline \multicolumn{3}{|l|}{ Use of sawtimber } \\
\hline \multicolumn{3}{|l|}{ Sawmill (115 MM fbm (LS)) } \\
\hline \multirow[t]{2}{*}{$<9$ inches (7 MM fbm (LS)) } & -7 & -7 \\
\hline & 130 & 149 \\
\hline$\geqslant 9$ inches (115-117 MM fbm (LS)) & -108 & -108 \\
\hline \multicolumn{3}{|l|}{ Volume available after satisfying } \\
\hline estimated sawmill demand & 22 & 41 \\
\hline
\end{tabular}

'Assumptions: (1) Entire Black Hills NF programmed harvest is available.

(2) Sawmills are able, if not willing, to take material less than 9 inches d.b.h.

(3) State and private harvest is not less than half the allowable cut and does not exceed allowable cut.

(4) Total sawtimber volume is in trees 8 inches d.b.h. or larger. 
1980, the Set Aside Program required preferential treatment of bids from small business on $67 \%$ of the sawtimber volume sold. In the next 5-year period the proportion of sawtimber allotted to small business set asides could increase or decrease slightly. However, the potential impact of the Set Aside Program would depend on the size of the firm operating a plywood plant.

In addition, a combination of existing Black Hills operators has announced plans to construct a waferboard plant in the Black Hills area (Forest Industries 1979). This plant is expected to utilize primarily small diameter roundwood not generally suitable for veneer blocks. There would not likely be much direct competition for timber between this waferboard plant and a piywood plant, with the possible exception of logs in the 8 - to 10 -inch d.i.b. range.

\section{The Second 10 Years, 1987-1996}

Under the non-declining, even-flow timber harvest policy of the USDA Forest Service, total cubic volume in the second decade of the Timber Management Plan is expected to be about the same as during the first decade. However, the proportion of sawtimber of larger sizes will probably decrease. The following tabulation shows the relation between sawtimber board foot volume and total cubic volume for the first two decades: ${ }^{18}$

\section{Volume cut}

\section{Decade 1 Decade 2}

Cubic-foot volume,

$\mathrm{M}$ cunits, all size classes $\quad 364.14 \quad 363.14$

Sawtimber volume,

$\mathrm{MM} \mathrm{fbm} \mathrm{(LS),} \mathrm{trees}$

10-inch d.b.h. class

and larger

110.67

87.61

Sawtimber volume,

$\mathrm{MM} \mathrm{fbm} \mathrm{(LS),} \mathrm{trees}$

8-inch d.b.h. class

and larger

117.99 Not available

Volume for trees 10 inches d.b.h. and larger is different for the two decades. Although total sawtimber volume includes trees down to 8 inches d.b.h., the assumption is that only trees 9 inches d.b.h. and greater (i.e., the 10-inch d.b.h. class using 2-inch d.b.h. classes) will be eligible for veneer blocks. Total sawtimber volume for the second decade is not available, but the figure pertinent to plywood manufacture is shown under decade 2 for sawtimber volume in trees in the 10-inch d.b.h. class and larger. Clearly, raw material for plywood would be less available in the second decade.

\footnotetext{
'Sources: Timber Management Plan, Black Hills National Forest 1977-1986. Final Environmental Statement for Timber Management Plan, Appendix Q, Black Hills NF. Computer printed output from Program GROW used in Ram Run 37 for the Timber Management Plan, on file at Rocky Mountain Forest and Range Experiment Station.
}

\section{QUALITY}

In addition to the gross amounts of raw material available, feasibility analyses must consider indicators of quality. In this study, the general aspects of quality were considered in terms of timber sale characteristics, log size distribution, and the main products available from Black Hills ponderosa pine.

Efficient plywood plant operation depends largely on having a favorable mix of log sizes available for manufacture; therefore, gross volumes alone do not adequately portray the suitability of the log supply. Estimates must be made of the material size likely to be in the plywood plant woodyard during a year of operation. The log mix that will actually be available to a plywood operation depends on a number of complex logistic factors and is somewhat indeterminate. How. ever, for this study, a log mix was chosen to reflect the tree sizes most likely to be cut as part of the current 10-year Timber Management Plan.

\section{Timber Sale Characteristics}

The assumed characteristics of timber sales are based on the Black Hills NF Timber Management Plan. The current 10-year Timber Management Plan for the Black Hills NF, as well as the planning for later 10-year periods, is based on timber classes. Timber classes define growing stock by size, density, and species (USDA Forest Service 1977). Timber is classified as sawtimber trees (8 inches d.b.h. or larger), poletimber trees (5-7.9 inches d.b.h.), and seedling and sapling trees (less than 5 inches d.b.h.). Density of stands is ranked in terms of basal area classes: less than 60 square feet per acre, 60-119 square feet per acre, and 120 square feet per acre and greater. Species groups are ponderosa pine and mixed species. The mixed species group is further classified into pine-spruce, spruce-pine, pine-aspen, and aspen-pine subgroups, depending on the predominant timber type.

The current Plan calls for harvesting timber from 395,525 acres over a 10-year period ending in 1986. Thirteen timber classes are specified for harvest in this period (table 12). Each timber class and its silvicultural prescription is described in the appendix. Of the 13 timber classes, seven comprise almost $97 \%$ of the total acreage to be harvested in the current Timber Management Plan period. Thus, these seven classes will be encountered in timber sales to a much greater degree than the remaining six timber classes. These seven timber classes, therefore, were analyzed by proportion of trees in each 2-inch diameter class. From this analysis three major groups of timber classes were developed as shown in figure 3.

One group, timber classes P61 and P21, has mostly small trees 8 inches d.b.h. and smaller scheduled for harvest. This group is not of major interest for plywood production. Timber class P21, with trees in the 10-inch class, is considered a sawtimber stand, but note that the largest d.b.h. class is only 10 inches. Timber class 
Table 12. - Timber class characteristics, Black Hills National Forest

\begin{tabular}{|c|c|c|c|c|c|}
\hline $\begin{array}{c}\text { Timber } \\
\text { class } \\
\text { designation' }\end{array}$ & $\begin{array}{c}\text { Acres } \\
\text { to be } \\
\text { cut, } \\
1977.1986\end{array}$ & $\begin{array}{c}\text { Basal } \\
\text { area } \\
\text { class }^{2}\end{array}$ & $\begin{array}{l}\text { Stand } \\
\text { size } \\
\text { class }^{3}\end{array}$ & $\begin{array}{l}\text { Dominant } \\
\text { species }^{4}\end{array}$ & $\begin{array}{l}\text { Site } \\
\text { index }\end{array}$ \\
\hline $\begin{array}{l}\text { P21 } \\
\text { PB1 } \\
\text { P31 } \\
\text { P61 } \\
\text { PA1 } \\
\text { SB1 } \\
\text { SC1 } \\
\text { WZS } \\
\text { TZB } \\
\text { TZN } \\
\text { TZA } \\
\text { N60 } \\
\text { NOR }\end{array}$ & $\begin{array}{r}108,787 \\
73,492 \\
68,813 \\
48,104 \\
35,788 \\
35,774 \\
11,117 \\
5,150 \\
4,000 \\
1,500 \\
1,000 \\
1,000 \\
1,000\end{array}$ & $\begin{array}{r}60-120 \\
60-120 \\
120+ \\
120+ \\
60- \\
120+ \\
120+ \\
120+ \\
60-120 \\
60-120 \\
60-120 \\
60-120 \\
\text { n.d. }\end{array}$ & $\begin{array}{l}S \\
S \\
S \\
P \\
S \\
S \\
S \\
S \\
S \\
S \\
S \\
S \\
S\end{array}$ & $\begin{array}{l}\text { PP } \\
\text { PP } \\
\text { PP } \\
\text { PP } \\
\text { PP } \\
\text { PS } \\
\text { SP } \\
\text { SP } \\
\text { PP } \\
\text { PP } \\
\text { PP } \\
\text { PP } \\
P P\end{array}$ & $\begin{array}{l}55 \\
55 \\
65 \\
58 \\
52 \\
62 \\
75 \\
75 \\
60 \\
60 \\
60 \\
55 \\
55\end{array}$ \\
\hline Total & 395,525 & & & & \\
\hline \multicolumn{6}{|c|}{$\begin{array}{l}\text { 'Explained in appendix. } \\
{ }^{2} 120+\text { means } 120 \text { square feet or greater; } 60-\text { means } 60 \text { square feet or less. } \\
{ }^{3} S-\text { sawtimber is predominant size; P-poletimber is predominant size. } \\
{ }^{4} P \text { - ponderosa pine; PS-mixed ponderosa pine and spruce with pine dominant; SP-mixed } \\
\text { onderosa pine and spruce with spruce dominant. } \\
{ }^{5} \text { Site index-100-year base. } \\
{ }^{6} \text { Timber class P21 is classified by Black Hills NF as sawtimber. However, the largest diam- } \\
\text { ter class represented is } 10 \text { inches. For the purposes of this study, it is classified in the pole- } \\
\text { mber group. }\end{array}$} \\
\hline
\end{tabular}

P61 is classified as poletimber even though it has trees in the 8-inch class, which are considered sawtimber. Consequently, these two timber classes are referred to here as the poletimber group.

The second group, timber classes PA1 and PB1, contains trees in d.b.h. classes 12 inches and larger. Timber sales featuring these two timber classes would have raw material of highest value for a plywood plant. These timber classes are referred to as the sawtimber group.

The third group, timber classes SC1, SB1, and P31, has both pole and sawtimber diameter classes. These timber classes are called the all-size group. Sales having these timber classes would contain raw material of value for plywood but would also include tree diameter classes too small for plywood. Under the multiproduct sale format of the Black Hills NF, purchasers must buy all timber included in the sale, not just certain size classes. Utilizing these small trees poses a challenge for some sawmill operators in the Black Hills, and likely would similarly affect a plywood plant.

Having established the proportions of trees, a timber buyer for a plywood mill would likely give highest priority to the sawtimber group. Next in desirability would be sales featuring the all-size group. Finally, the buyer might consider the poletimber group because it does contain some 9- and 10-inch d.b.h. trees but would probably avoid sales featuring this group if at all possible.
As indicated in the previous discussion, these seven timber classes make up the vast majority of acreage in timber sales until 1986. Acreage for the three groups of timber classes is shown as follows:

\section{Group (timber classes)}

Sawtimber (PB1, PA1)

All-size (P31, SB1, SC1)

Poletimber (P21, P61)

\section{Acreage}

109,280

115,704

156,891
Acreage is roughly equal in the two groups most useful for plywood. Assuming sales in the poletimber group are of little interest, there is about an equal chance of encountering sales composed of the sawtimber and allsize groups, which together represent about $57 \%$ of the total area to be harvested under the current Timber Management Plan.

\section{Log Size Distribution}

An estimate of the distribution of log sizes that reasonably could be expected to come from each of the two groups of primary interest is extremely important in the operating economics of a plywood plant. The timber class with the largest acreage from each group was selected to represent the group-class P31 represents the all-size group, and timber class PB1 represents the sawtimber group. 
Small end diameters inside bark ( d.i.b.) for 8.5-foot veneer blocks were grouped into 1-inch d.i.b. classes for each timber class. Because the two timber class groups-sawtimber and all-size-had about equal acreage, the numbers of 8.5 -foot veneer blocks in each d.i.b. class were averaged without weighting. It was assumed that, on an annual basis, a plywood plant would have access to a variety of sales from each timber class group, and that the d.i.b. distribution of veneer blocks would be similar to the computed values. A more complete discussion of methods involved in computing the veneer block distribution is contained in the appendix.

The curve for all 8.5-foot logs in figure 4 is a composite of proportions of logs from the all-size group and sawtimber group. Logs 4 and 5 inches d.i.b. come only from the all-size group. Logs 6 inches and larger come from both timber class groups. There are few logs less than 6 inches d.i.b. cut from large ponderosa pine trees because of the form of the upper bole.

The 6-inch division point also reflects a utilization limit prescribed by the Black Hills NF.20 This limit

${ }^{20}$ USDA Forest Service, Rocky Mountain Region. 1978. Supplement to the Forest Service Manual, Title 2400, Timber Management. R-2 Suppl. 236. Page 2451.22-3.

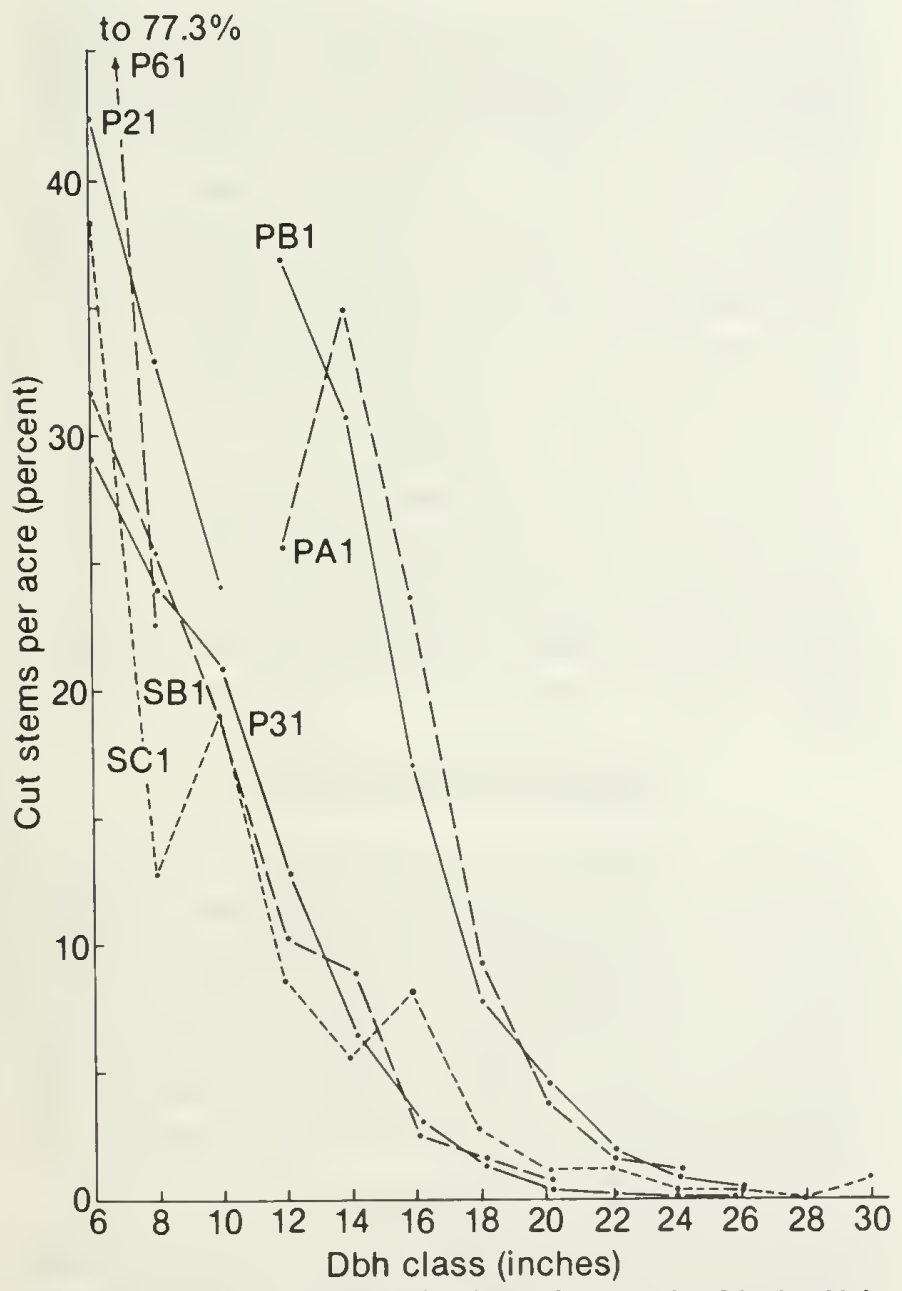

Figure 3.-Proportional distribution of trees in 2-inch d.b.h. classes for timber management tree classes on the Black Hills National Forest.

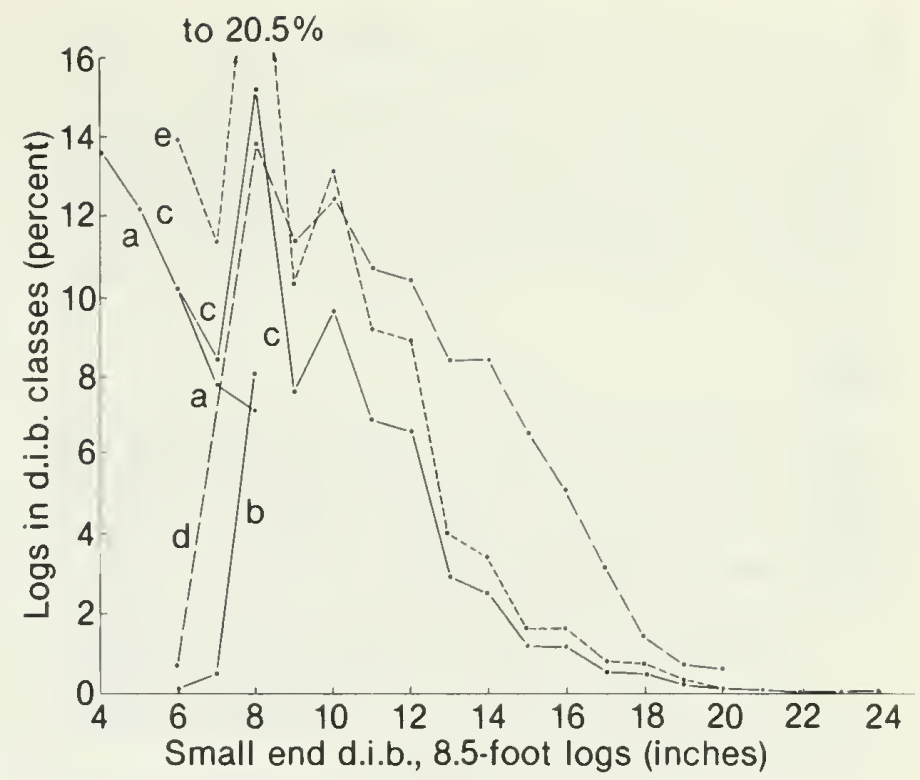

Figure 4.-Proportions of logs in 1.inch classes for small end, diameter inside bark (d.i.b.). Results based on tree distribution data from Black Hills National Forest timber classes PB1 and P31: $a=\operatorname{logs} \leqslant 8$ inches d.i.b. from small trees; $b=\operatorname{logs}$ $\leqslant 8$ inches and less d.i.b. from large trees; $c=$ logs in all d.i.b. classes from all trees; $d=$ logs in study of veneer recovery (Yerkes and Woodfin 1972), $\geqslant 6$ inches d.i.b. at the small end; $e=\log$ in this study $\geqslant 6$ inches d.i.b.

specifies that sawtimber trees, those with d.b.h. 8 inches or larger, must be cut to a 6-inch d.i.b. top or less, provided the tree contains at least one 8-foot log. However, the utilization limits specify that poletimber trees, those with d.b.h. between 5 and 8 inches, must be cut to a 4-inch d.i.b. top or less, and must contain at least two "pieces" (logs) of 8.33 feet each (i.e., one log of 16.67 feet).

Note in figure 4 that both timber class groups contribute substantial numbers of 8-inch logs, and when combined, the proportion of logs in this d.i.b. class is the largest of all d.i.b. classes.

In d.i.b. classes larger than 8 inches, the proportion of logs decreases with an increase in diameter. Logs 20 inches d.i.b. or greater are few, but some can be expected.

Superimposed on figure 4 is the proportional distribution of small end d.i.b.'s for 8.5-foot veneer blocks measured by Yerkes and Woodfin (1972) in their veneer recovery study. Large logs are heavily represented, because large trees were deliberately included to insure an adequate number of peelable blocks in the sample. Logs processed in that veneer recovery study were 6 inches or larger, d.i.b., so comparable log sizes in this study are shown in figure 4 .

\section{Product Characteristics}

Given the expected numbers of multiproduct timber sales offered by the Forest Service in the Black Hills, purchasers must expect that they will have to handle material that does not fit the mainstream of their 
operations. In the case of a projected plywood plant, this material would include logs too small for peeling, veneer block cores, and various kinds of residue, such as clipper trim, lily pads, or bark. To help estimate the amounts and kinds of products and by-products that would be generated, a general assessment of the characteristics of plywood, lumber, and residue product classes was made.

\section{Veneer}

The amounts and grades of veneer recoverable from Black Hills ponderosa pine are described in previous research (Yerkes and Woodfin 1972). Conclusions drawn from that research are:

1. A sample of 144 Black Hills ponderosa pine trees, from six d.b.h. classes, meeting defect criteria of the study, yielded veneer in a proportion of grades and sizes that was more than adequate to produce C-D grade, 3/8-inch, 3-ply plywood.

2. Trees in larger diameter classes yielded a higher percentage of veneer but lower percentages of $\mathrm{C}$ and better $(\mathrm{C}+)$ grades than trees in smaller diameter classes.

3. Larger diameter veneer blocks yielded slightly higher percentages of $\mathrm{C}+$ grades than did smaller diameter blocks.

4. Blocks in lower tree positions yielded larger proportions of $\mathrm{C}+$ grades of veneer than blocks in higher tree positions.

5. Recovery ratios appeared favorable for conversion of trees to plywood, except for trees and blocks of small diameters. ${ }^{21}$

6. More than enough full width sheets of $\mathrm{C}+$ and $\mathrm{D}$ grades of veneer were recovered to provide onepiece face plies, even if all plywood that could have been produced in this study were $3 / 8$-inch, 3-ply panels.

7. Knot size, as visually estimated on the veneer blocks, was a useful means of separating the blocks into two classes yielding significantly different proportions of $\mathrm{C}+$ veneer.

8. Recovery data varied widely with all classes of trees and blocks. However, it is believed that any large sample of Black Hills trees in these diameters would give nearly the same veneer гесоvery as those in this study.

\section{Lumber}

Boards and dimension lumber, including studs, are the principal products now manufactured from Black Hills ponderosa pine. Because many plywood plants are associated with a sawmill, log allocation for use in lumber or plywood is influenced by product recovery

\footnotetext{
"'Small diameters" means trees of 9 and 10 inches d.b.h. and veneer blocks smaller than 9 inches d.i.b. When this cited research was done in 1968, the existing "state-of-the-art" in plywood manufacture made this statement generally true. However, recent advances in green end technology for small diameter blocks have made this constraint much less binding on raw material supply.
}

and value. For purposes of this study, it was assumed that the associated sawmill would exist only as an auxillary to the plywood operation and would utilize only the logs that could not be profitably utilized in veneer.

The most recent lumber grade recovery study published for the Black Hills found a high proportion of the volume in Common grades of boards (Mueller and Kovner 1967). Log diameters in the study were typical of the Black Hills area-from 8 to 20 inches-and log grades were mostly Number 3 and Number 5. Approximately $75 \%$ of the lumber volume was about evenly divided between lumber grades 1 and 2 Common, 3 Common, and 4 Common. Lumber volume in grade 5 Common, as reported in the study, resulted only from downgrading of the higher grade lumber in the seasoning and surfacing operations. Some grade 5 Common lumber was discarded in the green state because it was considered unmerchantable.

The most likely lumber product from a plywood plant-sawmill complex will be 2- by 4-inch or possibly 2-by 6-inch dimension stock. However, no published data currently exist describing grade recovery of dimension products from Black Hills ponderosa pine.

\section{Residue}

Most residue from current sawmill operations in the Black Hills is underutilized. Some chips are shipped to pulp mills in the Great Lakes region. The market for salable residue, however, is sporadic. Another outlet for much of this residue could be particleboard, if this commodity were to be manufactured in the Black Hills (Markstrom et al. 1976). There is considerable interest in the Black Hills area in promoting some type of composition board plant. Such a facility could provide an outlet for mill residue and/or large volumes of small roundwood of less than 8 inches d.b.h. ${ }^{11}$

Another utilization opportunity in the Black Hills area is some type of composite panel product with veneer face plies over a particleboard core. ${ }^{22} \mathrm{~A}$ product of this type could advantagously utilize C and D grade veneer for faces and backs while reducing the D grade veneer required fог interior plies. Plant residues possibly could be utilized for the composition board core.

\section{OPERATING ECONOMICS}

Economic estimates in this section аге necessarily based on a number of informed judgments, since no history of plywood production exists for the Black Hills. However, most economic factors are expected to be similar to those for plants of comparable size and type in other areas. This section is based on an economic analysis conducted within projected technology, and coupled with the previous assessment of markets and raw material conditions. ${ }^{23}$

${ }^{22}$ Personal communication from R. F. Baldwin, Camden, Tex.

${ }^{23}$ Unless otherwise noted all cost estimates in this section are based on an engineering analysis, "Black Hills Plywood Study" by Frank Hahn, Senior Consultant, formerly with H. C. Mason and Associates, Inc. 1978. This analysis was performed under contract 43-82-FT-7-556. 


\section{Plant Size}

The size of plywood plants that can operate economically has increased steadily over the years to spread rising fixed costs over greater plywood output. Figure 5 shows the production capacity distribution of U.S. softwood plywood plants in early 1977. The minimum capacity for an operating U.S. plant is about $40 \mathrm{MM} \mathrm{ft}^{2}$ annually (3/8-inch basis).

The range of plant sizes that were considered in this study runs from about 40 to $70 \mathrm{MM} \mathrm{ft}^{2}$ capacity, 3/8-inch basis. A smaller plant probably is not economical, and log volume is not available for a sufficient time to amortize a large plant. Capital equipment required under the assumed operating format is about the same for whichever plywood level is produced-40 $\mathrm{MM}$ or $70 \mathrm{MM} \mathrm{ft}^{2}$. The largest difference in the two production capacities is the number of operating shifts per day and the resulting direct labor cost. Consequently, the only plant size discussed here is in the range of $60-70 \mathrm{MM} \mathrm{ft}^{2}$ annual production.

Although no mills have been built in the last 10 years with less than $100 \mathrm{MM} \mathrm{ft}^{2}$ capacity, ${ }^{8}$ it should be noted that job counts, equipment, and variable operating costs for a plant with $70 \mathrm{MM} \mathrm{ft}^{2}$ capacity are not much different than for a larger plant. ${ }^{24}$

"Personal communication from R.F. Baldwin, Camden, Tex.
In the assumed operating format, logs are delivered from the woodyard to the debarker deck by front-end grapple loader. After debarking, logs are conveyed to the cut-off saw and cut to 102-inch blocks. Blocks of less than peelable diameter are diverted to a chipping headrig for stud manufacture.

Veneer blocks are sorted into several diameter classes, steamed, ${ }^{25}$ and delivered to the lathe-charger system. The veneer green chain is close coupled with a veneer scanner triggering the clipper. Clipped, green veneer is manually pulled and stacked. The jet dryer has drying capacity (sections) proportional to plant capacity, plus two cooling sections. A patch and reclip system is used for veneer repair. Hand layup of dry veneer uses a spreader, prepress, press sequence.

Panels are trimmed, repaired (if product requires), bundled, palleted, and stored for shipment by truck or rail.

Wood waste in the form of short blocks, lily pads, slabs, edgings, bark, and fishtails is chipped and sold, or hogged to fuel a wood-fired boiler, depending on the relationship between energy needs and alternative outlets. Chips from the sawmill and plywood plant are sold in the most advantageous markets.

The associated sawmill produces mostly stud lumber from cores and logs not suitable for veneer. Lumber is sold kiln dried or rough green, depending on markets.

\footnotetext{
${ }^{25}$ Conditioning logs in hot water vats instead of in steam tunnels is frequently preferred, but because of the possibility of water pollution problems, steam tunnels were assumed for the plant configuration.
}

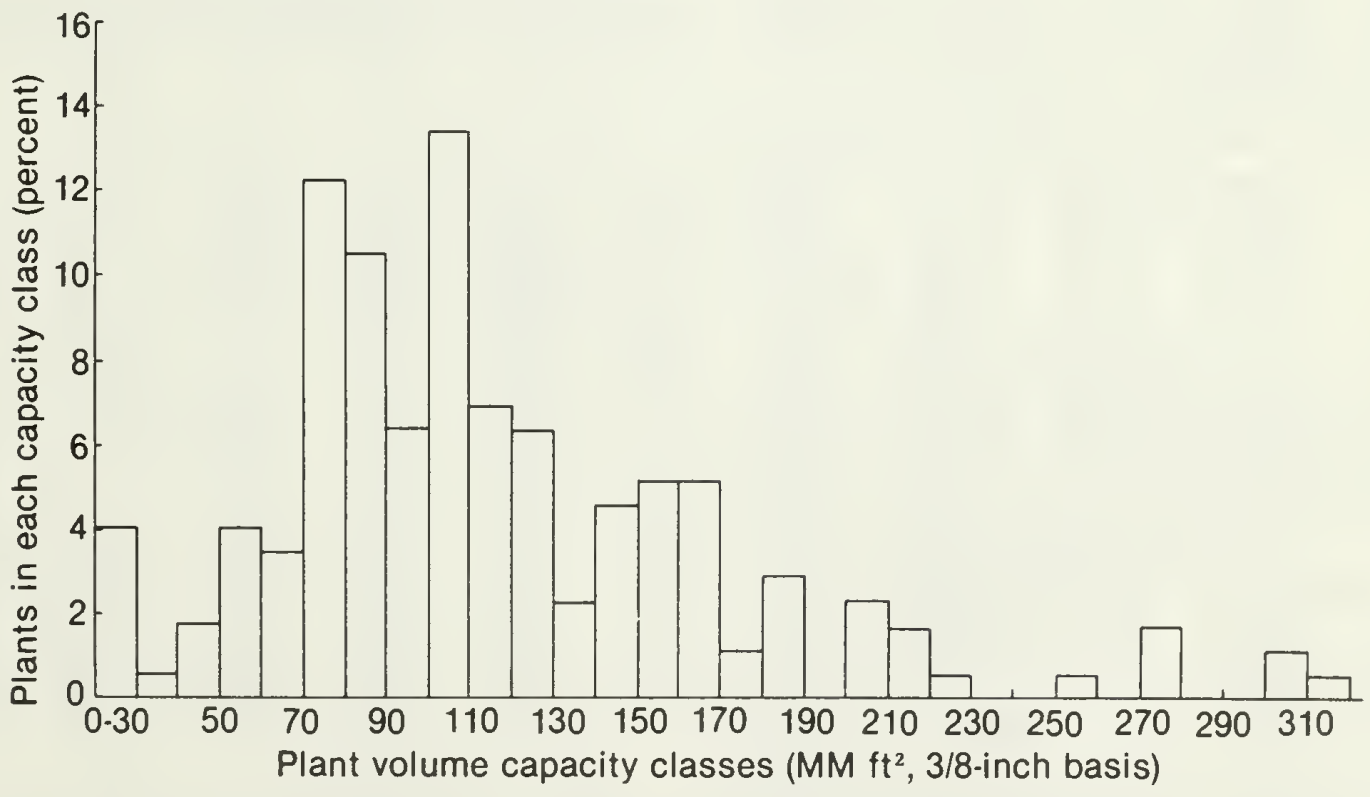

Figure 5.-Production capacity distribution of U.S. softwood plywood plants, 1977 (Forest Industries 1977). 


\section{Product Output}

It might be assumed that all log sizes not suitable for peeling could be sold or traded to others, but such an arrangement does not conform to current industry patterns and therefore is not assured. It may be more realistic to assume that the plywood mill would be responsible for processing or otherwise disposing of all timber it purchased. If so, products likely to be produced are plywood (veneer), studs, chips, bark, and coarse and fine residues.

To estimate total volumes of these products, figures were compiled on expected recovery of each product, by diameter, for veneer blocks or stud logs. These recoveries were applied to the expected log size distribution and volume to estimate total product output. ${ }^{28}$

\section{Veneer and Residue Recovery Per Log}

Veneer yields by block diameter were computed by regression equations based on published material (Yerkes and Woodfin 1972, Woodfin 1973). This approach allows estimates of veneer recovery and residue generation for block diameters slightly larger than those listed in the reported research. Table 13 shows

${ }^{26}$ The three possible outputs of this plywood complex-ply. wood panels, lumber, and residue-each have units of measure commonly associated with the product such as square feet, board feet lumber tally and ovendry tons, respectively. Logs, in turn, are commonly measured in board feet, Scribner Decimal C log scale, in the Black Hills. To achieve consistency in measurement this economic analysis is expressed in terms of cubic feet, with the corresponding volume measurements in the usual units shown as companion figures. the material volume allocation for veneer blocks of various diameters, estimating total block volume, tangible loss volume, veneer shrinkage volume, and finally, green and dry veneer volumes for three target core sizes. ${ }^{27}$ Tangible losses consist of round-up volume, end spur, and clipper loss. Details about the derivation of this table are found in the appendix.

\section{Stud and Residue Recovery Per Log}

There are no published data for stud recovery from Black Hills ponderosa pine logs. Consequently, stud recovery and residue generation was estimated by considering theoretical sawing diagrams for 8.5 -foot stud logs.

It is assumed that three classes of logs based on log taper would be available to a sawmill auxiliary to the assumed plywood plant. First are logs without taper; that is, cores from the veneer lathe. Second are small logs with taper not greater than 1 inch per 8.5 feet. These logs tend to originate in trees smaller than 9 inches d.b.h., the lower limit set for trees with peelable blocks. Third are small logs that originate in the upper bole of trees cut for veneer blocks. Generally, these logs will have numerous large knots and severe taper resulting from the growth characteristics and stem form of Black Hills ponderosa pine. (See appendix sections, "Computation of Log Taper" and "Lumber and Residue Recovery.")

\footnotetext{
${ }^{27}$ One way to increase veneer recovery is to install 4-foot core lathe equipment. However, the economic impact of this option was not analyzed in this study.
}

Table 13.-Veneer block material allocation (cubic feet) by block diameter class (inches) and target core diameters'

\begin{tabular}{|c|c|c|c|c|c|c|c|c|c|c|}
\hline \multirow{3}{*}{$\begin{array}{c}\text { Block } \\
\text { diameter } \\
\text { class }\end{array}$} & \multirow{3}{*}{$\begin{array}{c}\text { Total } \\
\text { volume } \\
\text { in one } \\
\text { block } \\
\text { (8.5 feet) }\end{array}$} & \multirow{3}{*}{$\begin{array}{l}\text { Loss } \\
\text { volume }\end{array}$} & \multirow{3}{*}{$\begin{array}{l}\text { Veneer } \\
\text { and core } \\
\text { volume }\end{array}$} & \multirow{3}{*}{$\begin{array}{c}\text { Shrinkage } \\
\text { volume }\end{array}$} & \multicolumn{6}{|c|}{ Target core diameters } \\
\hline & & & & & \multicolumn{2}{|c|}{6 inches } & \multicolumn{2}{|c|}{5 inches } & \multicolumn{2}{|c|}{4 inches } \\
\hline & & & & & Green & Dry & Green & Dry & Green & Dry \\
\hline 6 & 3.0828 & 1.0528 & 2.0300 & 0.0120 & 0.3611 & 0.3491 & 0.8710 & 0.8590 & 1.2883 & 1.2763 \\
\hline 7 & 3.3054 & 1.0354 & 2.2700 & 0.0132 & 0.6011 & 0.5879 & 1.1110 & 1.0978 & 1.5283 & 1.5151 \\
\hline 8 & 3.6120 & 1.1020 & 2.5100 & 0.0347 & 0.8411 & 0.8064 & 1.3510 & 1.3163 & 1.7683 & 1.7336 \\
\hline 9 & 3.9925 & 1.2526 & 2.7399 & 0.0719 & 1.0710 & 0.9991 & 1.5809 & 1.5090 & 1.9982 & 1.9263 \\
\hline 10 & 5.1558 & 1.4872 & 3.6686 & 0.1114 & 1.9997 & 1.8883 & 2.5096 & 2.3982 & 2.9269 & 2.8155 \\
\hline 11 & 6.4031 & 1.8058 & 4.5973 & 0.1665 & 2.9284 & 2.7619 & 3.4383 & 3.2718 & 3.8556 & 3.6891 \\
\hline 12 & 7.7344 & 2.2084 & 5.5260 & 0.2197 & 3.8571 & 3.6374 & 4.3670 & 4.1473 & 4.7843 & 4.5646 \\
\hline 13 & 9.1497 & 2.6950 & 6.4547 & 0.2782 & 4.7858 & 4.5076 & 5.2957 & 5.0175 & 5.7130 & 5.4348 \\
\hline 14 & 10.6490 & 3.2656 & 7.3834 & 0.3376 & 5.7145 & 5.3769 & 6.2244 & 5.8868 & 6.6417 & 6.3041 \\
\hline 15 & 12.2323 & 3.9202 & 8.3121 & 0.3963 & 6.6432 & 6.2469 & 7.1531 & 6.7568 & 7.5704 & 7.1741 \\
\hline 16 & 13.8996 & 4.6588 & 9.2408 & 0.4323 & 7.5719 & 7.1396 & 8.0818 & 7.6495 & 8.4991 & 8.0668 \\
\hline 17 & 15.6509 & 5.4814 & 10.1695 & 0.5180 & 8.5006 & 7.9826 & 9.0105 & 8.4925 & 9.4278 & 8.9098 \\
\hline 18 & 17.4862 & 6.3880 & 11.0982 & 0.5403 & 9.4293 & 8.8890 & 9.9392 & 9.3989 & 10.3565 & 9.8162 \\
\hline 19 & 19.4005 & 7.3786 & 12.0269 & 0.6055 & 10.3580 & 9.7525 & 10.8679 & 10.2624 & 11.2852 & 10.6797 \\
\hline 20 & 21.4088 & 8.4532 & 12.9556 & 0.6455 & 11.2867 & 10.6402 & 11.7966 & 11.1501 & 12.2139 & 11.5674 \\
\hline 21 & 23.4961 & 9.6118 & 13.8843 & 0.7378 & 12.2154 & 11.4776 & 12.7253 & 11.9875 & 13.1426 & 12.4048 \\
\hline 22 & 25.6674 & 10.8544 & 14.8130 & 0.8060 & 13.1441 & 12.3381 & 13.6540 & 12.8480 & 14.0713 & 13.2653 \\
\hline 23 & 27.9227 & 12.1810 & 15.7417 & 0.8768 & 14.0728 & 13.1960 & 14.5827 & 13.7059 & 15.0000 & 14.1232 \\
\hline 24 & 30.2620 & 13.5916 & 16.6704 & 0.9502 & 15.0015 & 14.0513 & 15.5114 & 14.5612 & 15.9287 & 14.9785 \\
\hline
\end{tabular}

'Discussion of the derivation of table values is found in the appendix. Four decimal places are carried here to insure that subsequent use of these figures will not introduce significant error caused by rounding. 
Table 14. - Theoretical 2- by 4-inch stud lumber and residue recovery from three classes of small diameter logs

\begin{tabular}{|c|c|c|c|c|c|c|c|c|c|c|c|c|}
\hline $\begin{array}{l}\log \\
\text { class }\end{array}$ & $\begin{array}{l}\text { Small } \\
\text { end } \\
\text { d.i.b. } \\
\text { class }\end{array}$ & $\begin{array}{l}\text { Total } \\
\text { volume }\end{array}$ & Chips & $\begin{array}{l}\text { Saw } \\
\text { kerf }\end{array}$ & $\begin{array}{l}\text { Lumber } \\
\text { rough, green } \\
\text { untrimmed }\end{array}$ & Trim & $\begin{array}{l}\text { Lumber } \\
\text { rough, green } \\
\text { trimmed }\end{array}$ & Shrink & $\begin{array}{l}\text { Planer, } \\
\text { sander } \\
\text { volume }\end{array}$ & $\begin{array}{l}\text { Lumber } \\
\text { dry, } \\
\text { dressed }\end{array}$ & $\begin{array}{l}\text { Nominal } \\
\text { lumber } \\
\text { tally }\end{array}$ & $\begin{array}{l}\text { Number } \\
\text { of pieces } \\
\text { recovered }\end{array}$ \\
\hline & inches & . & ......... & 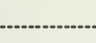 & 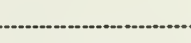 & $\ldots . . . . c u$ & bic teet & 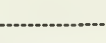 & & 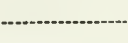 & $\mathrm{fbm}$ & \\
\hline $\begin{array}{l}\text { Lathe cores } \\
\text { (no taper) }\end{array}$ & $\begin{array}{l}4 \\
5 \\
6\end{array}$ & $\begin{array}{l}0.742 \\
1.159 \\
1.669\end{array}$ & $\begin{array}{l}0.377 \\
0.396 \\
0.517\end{array}$ & $\begin{array}{l}0.033 \\
0.066\end{array}$ & $\begin{array}{l}0.365 \\
0.730 \\
1.086\end{array}$ & $\begin{array}{l}0.021 \\
0.043 \\
0.064\end{array}$ & $\begin{array}{l}0.344 \\
0.687 \\
1.022\end{array}$ & $\begin{array}{l}0.024 \\
0.048 \\
0.072\end{array}$ & $\begin{array}{l}0.028 \\
0.056 \\
0.084\end{array}$ & $\begin{array}{l}0.292 \\
0.583 \\
0.866\end{array}$ & $\begin{array}{r}5.333 \\
10.667 \\
16.000\end{array}$ & $\begin{array}{l}1 \\
2 \\
3\end{array}$ \\
\hline $\begin{array}{l}\text { Small tree } \\
\text { logs (low taper) }\end{array}$ & $\begin{array}{l}4 \\
5 \\
6 \\
7 \\
8\end{array}$ & $\begin{array}{l}0.950 \\
1.414 \\
1.970 \\
2.619 \\
3.361\end{array}$ & $\begin{array}{l}0.585 \\
0.651 \\
0.808 \\
1.058 \\
1.004\end{array}$ & $\begin{array}{c}\ddot{.} \\
0.033 \\
0.066 \\
0.100 \\
0.166\end{array}$ & $\begin{array}{l}0.365 \\
0.730 \\
1.096 \\
1.461 \\
2.191\end{array}$ & $\begin{array}{l}0.021 \\
0.043 \\
0.064 \\
0.086 \\
0.129\end{array}$ & $\begin{array}{l}0.344 \\
0.687 \\
1.032 \\
1.375 \\
2.062\end{array}$ & $\begin{array}{l}0.024 \\
0.048 \\
0.072 \\
0.097 \\
0.145\end{array}$ & $\begin{array}{l}0.028 \\
0.056 \\
0.084 \\
0.112 \\
0.168\end{array}$ & $\begin{array}{l}0.292 \\
0.583 \\
0.876 \\
1.166 \\
1.749\end{array}$ & $\begin{array}{c}5.333 \\
10.667 \\
16.000 \\
21.333 \\
32.000\end{array}$ & $\begin{array}{l}1 \\
2 \\
3 \\
4 \\
6\end{array}$ \\
\hline $\begin{array}{l}\text { Large tree } \\
\text { logs (high taper) }\end{array}$ & $\begin{array}{l}6 \\
7 \\
8\end{array}$ & $\begin{array}{l}2.883 \\
3.272 \\
3.811\end{array}$ & $\begin{array}{l}1.721 \\
1.711 \\
1.444\end{array}$ & $\begin{array}{l}0.066 \\
0.100 \\
0.166\end{array}$ & $\begin{array}{l}1.096 \\
1.461 \\
2.191\end{array}$ & $\begin{array}{l}0.064 \\
0.086 \\
0.129\end{array}$ & $\begin{array}{l}1.032 \\
1.375 \\
2.062\end{array}$ & $\begin{array}{l}0.072 \\
0.097 \\
0.145\end{array}$ & $\begin{array}{l}0.084 \\
0.112 \\
0.168\end{array}$ & $\begin{array}{l}0.876 \\
1.166 \\
1.749\end{array}$ & $\begin{array}{l}16.000 \\
21.333 \\
32.000\end{array}$ & $\begin{array}{l}3 \\
4 \\
6\end{array}$ \\
\hline
\end{tabular}

Lathe cores.-For the veneer recovery study (Yerkes and Woodfin 1972), core size averaged close to 6 inches for all block diameters. However, current industry practice, especially in high-volume, small-log veneer plants, tends toward the 4-inch diameter target core size.

The core size decision not only affects veneer recovery, but also determines stud recovery. Table 14 shows the theoretical possibilities for lumber recovery from core logs in each diameter class and estimates of residues generated.

Low-taper logs.-As mentioned in the section on timber resources, logs in the 8-inch small end d.i.b. class will likely occur in greater proportion than other d.i.b. classes. The engineering analysis, however, recommends peeling only logs 9 inches and larger. This would mean allocating the largest proportionate log class, originating in both multiproduct and sawlog timber sales, to lumber manufacture. In turn, volumes of logs 9 inches and larger would need to be increased to maintain plywood production at capacity. Peeling 8-inch logs may increase operating costs, but this potential negative effect is less than that introduced by having to purchase significantly more stumpage. Also, making studs from the large volume of 8-inch logs would, in effect, require a sizable sawmill with an associated plywood plant. This runs counter to the original purpose of this study, which was to determine the feasibility of a plywood plant with a small sawmill added to upgrade utilization.

Table 14 lists stud lumber and residue recovery for 8.5 -foot logs with d.i.b.'s from 4 to 8 inches. While the larger logs could yield lumber other than studs, considering a wider range of possibilities for this study would have obscured the main comparisons. The assumed sawn product, therefore, was restricted to stud lumber.
High taper logs.-Taper in these logs is much more variable, because the logs are cut from trees with a wide variety of diameters and heights. Assumptions for taper are as follows:

$\begin{array}{cc}\begin{array}{c}\text { Log d.i.b. } \\ \text { class }\end{array} & \text { Taper per 8.5-foot log } \\ \text { inches } & \text { inches } \\ 6 & 3.4 \\ 7 & 2.6 \\ 8 & 2.0\end{array}$

Small end log diameters in table 14 range from 6 to 8 inches for this taper class. Few high taper logs should be less than 6 inches d.i.b., because they come from sawtimber size trees that have a 6-inch top utilization limit.

\section{Bark Recovery}

Bark volume was not computed on a per-log basis, as was done for veneer and lumber, because no published data were available to support such computations. Instead, data were used that estimate the bark produced per cubic foot of wood processed for each 4-inch diameter class (Krier and River 1968).

Complete computations for bark volume are given in the appendix section "Bark Volume." The basic approach was to segment the assumed log distribution into diameter classes compatible with those for which data were available. The result is that bark volume generated is 100 cubic feet for each group of 100 logs 8.5 feet in length distributed with respect to small end d.i.b., as previously assumed. 


\section{Log Distribution and Index Volumes}

Tables 13 and 14 show how individual logs of each size class would contribute to product output, bark excepted. The essential question, then, is to determine whether the proportionate log size mix discussed earlier would yield sufficient veneer to support the plant target annual output of $62.5 \mathrm{MM} \mathrm{ft}^{2}, 3 / 8$-inch basis.

To compute total requirements, a quantity called "index log volume" was defined. This index volume is for 100 logs with small end diameters distributed as in figure 4. For example, of the 100 logs, 15.2082 logs have diameters in the 8-inch class, 6.5903 logs have diameters in the 12-inch class, etc. Dealing with such precise decimal parts of logs is theoretical but will result in a more accurate estimate when transformed to a basis of total number of logs required annually.

The following part of the analysis is based on assumptions about future plywood management decisions with respect to the veneer block lower diameter limit and to the target core size.

Three levels each of block diameters and core diameters have been considered-9, 8, and 7 inches (d.i.b. small end) for veneer block lower size limit, and 6, 5, and 4 inches for target core size. The analysis for each of the nine combinations has been carried to the point of illustrating log volumes required and product volumes generated under each combination.

Complete tables for product and residue volumes are given in the appendix (tables A-4, A-5, A-6) for each of the nine combinations of veneer block size lower limit and target core diameter. Some of this information is summarized in figure 6 which shows how plywood and lumber volumes, obtained from an index log volume, will vary depending on the assumed combination of lower veneer block limit and core size. Note the relationship between plywood and lumber volumes. For example, peeling veneer blocks 9 inches and larger to a 6-inch core yielded the lowest cubic foot plywood volume but the highest cubic foot lumber volume per 100 index logs.

\section{Total Product and Residue Volumes}

The final step in analysis of estimated product output is to divide the index volumes based on log size distribution into the total volumes required to achieve an annual plywood production level of $62.5 \mathrm{MM} \mathrm{ft}^{2}$, 3/8-inch basis, which is equivalent to $1,953,125$ cubic feet or to $19.53 \mathrm{M}$ cunits. ${ }^{28}$ This assumed cubic volume of finished plywood can be traced back to the beginning of the production process to determine what volume of logs will supply the veneer volume required.

Figure 7 traces the flow of wood material through the plywood complex as conceived. Two primary flows

${ }^{28}$ One cunit is 100 cubic feet of wood; one $M$ cunit is 100,000 cubic feet of wood. Although the cunit generally is used to measure roundwood products such as sawlogs or pulpwood, it is used here as a convenient, product-independent measure of solid volume. are necessary to process all logs-one for plywood and one for lumber. In addition, veneer block cores enter the lumber flow.

As shown in figure 7 , the $19.53 \mathrm{M}$ cunits of finished plywood-banded, stacked, ready for shipment-is net of trim and other dry veneer loss incurred from veneer dryer output to shipping dock.

Two veneer recovery studies (Hunt and Woodfin 1970, Woodfin and Pong 1972), each found that approximately $16 \%$ of dry, untrimmed veneer is lost in the dry chain and panel layup. Losses at this step in plywood production are largely dependent on mill efficiency and production technology. Because two independent studies reported similar results, it was assumed that the proposed mill would experience a similar loss of $16 \%$.

To provide the required plywood volume $\left(62.5 \mathrm{MM} \mathrm{ft}^{2}\right.$, $3 / 8$-inch basis), allowing for a dry veneer loss of $16 \%$, the annual gross veneer volume from the dryer must be $2,325,149$ cubic feet, or 23,250 cunits.

To produce 23,250 cunits of dry veneer annually requires an input log volume that depends on target core size and lower veneer block diameter limit. Total required log volume increases dramatically as target core size increases or as veneer block lower limit increases (fig. 8). Methods used to compute these alternative volumes are presented in the appendix.

An interesting consequence of decisions about the minimum block diameter and target core diameter is

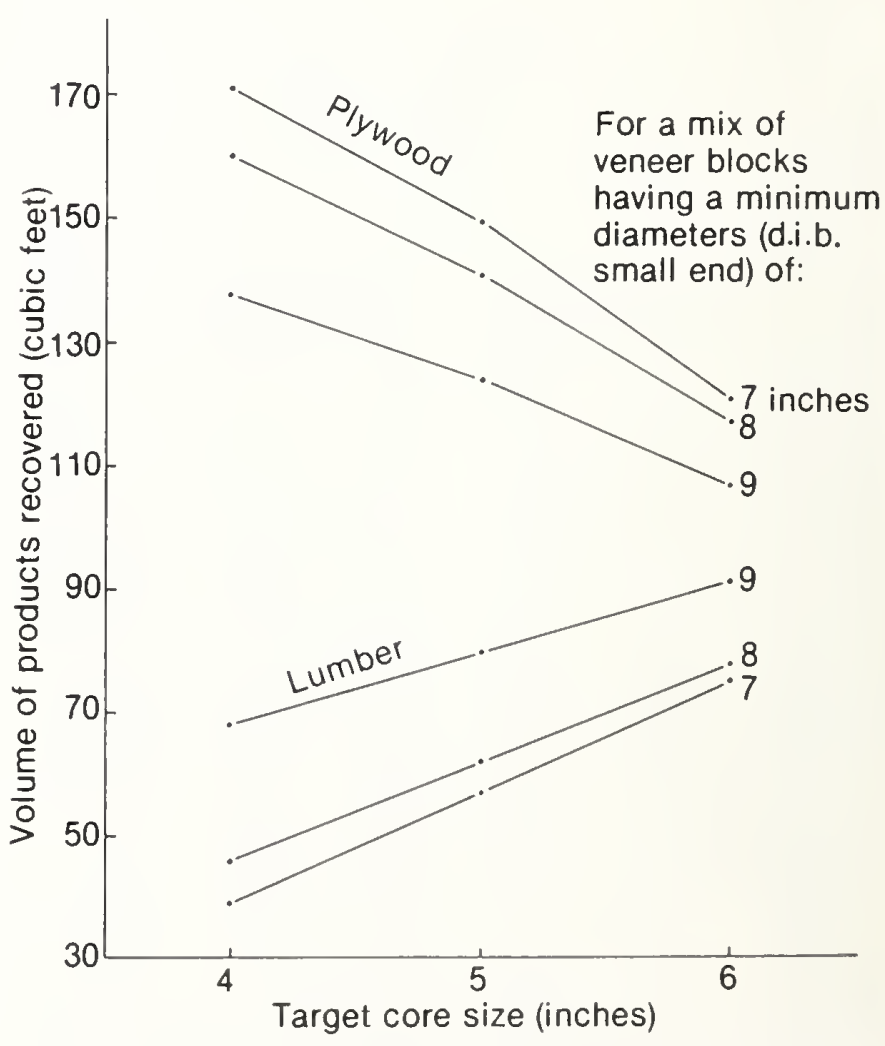

Figure 6. - Plywood and lumber product volume per $100 \mathrm{log}$ index unit as a function of target core size and veneer block lower diameter limit. 


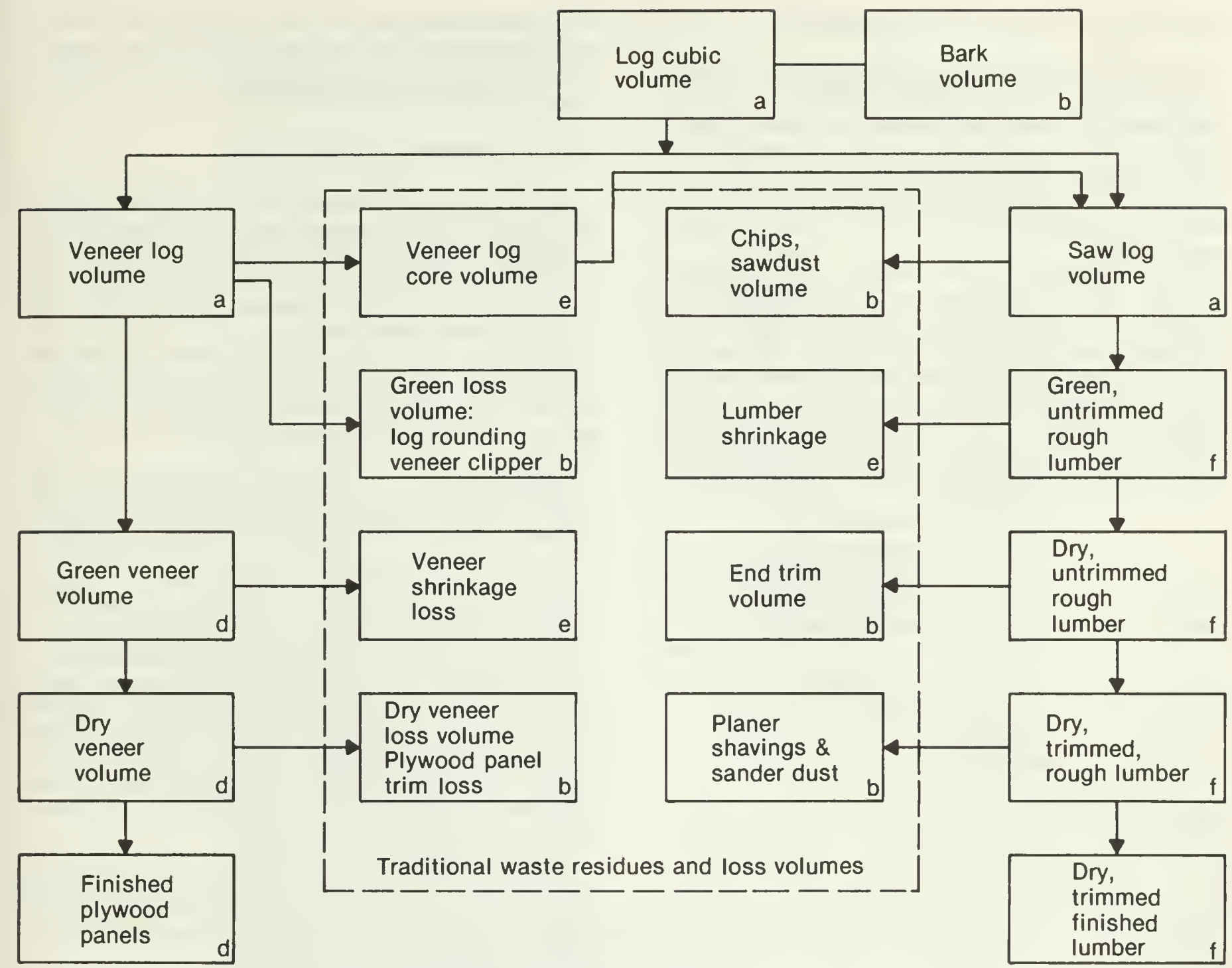

Flgure 7.-Prlmary process steps and resulting intermediate products and by-products for plywood and lumber manufacture: (a) can also be measured in terms of board foot log rule volume; (b) traditional measurement unlt is oven-dry tons (O.D.T.); (c) traditional measurement unit is a ratio-square foot, $3 / 8$-inch basis, per board foot; (d) traditional measure unit is square feet, $3 / 8$-Inch basis; $(\theta)$ has no traditional measurement unit; (f) traditional measurement unit is foot board measure, lumber tally basis (fbm (LT)).

the change in potential lumber output in the form of 2 - by 4-inch studs. As the lower limit of veneer block diameters increases, lumber volume increases significantly. This happens because small logs not peeled must be disposed of at the sawmill. Product volumes for all nine combinations of target core sizes and veneer block lower limit can be computed from tables A-4, A-5, A-6. In figure 8, the distance between curves for total lumber and plywood volumes and total required wood volume represents residues of various kinds.

For the remainder of this analysis, plywood operations are based on peeling veneer blocks 8 inches and greater to a 4-inch target core. This assumption is an economic compromise between the two extreme combinations of 9-inch blocks to a 6-inch core and 7-inch blocks to a 4-inch core. It allocates to plywood the large supply of 8-inch logs and incorporates capabilities of modern plywood technology to peel blocks to a 4-inch core. Annual material requirements for the assumed management option are presented in table 15.

\section{Economics}

In this analysis, costs that are largely uncontrollable by plant management, such as log and energy costs, were separated for detailed analysis of their effects. For controllable costs it was assumed that the experience of producers with similarly configured plants in other areas was representative of the Black Hills. Some variation in labor cost can be expected with location, but most in-plant processing costs would be nearly the same whether the plant is located in South Dakota, Wyoming, or elsewhere. The engineering study mentioned previously supplied the basic data for in-plant costs. 


\section{The Cash Flow Analysis (CFA) Approach}

A computer program was used to provide an analysis of discounted cash flows (Harpole 1978). The CFA computer program computes the after-tax value of investment cash flows over time. Results are presented in terms of present value of investment and internal rate of return. Also available is the total unit cost of production, or break-even price, under varying levels of input variables.

When analyzing cash flow with the CFA computer program, the only serious, but not insurmountable, limitation concerns units of measure for dealing with multiple products from the same facility. Because apportioning fixed and variable costs to several products was not practical in this case, a method was needed to realistically assign costs to plywood, lumber, and salable residues. The method used initially figures costs in units appropriate to each product and then

For a mix of veneer blocks having minimum

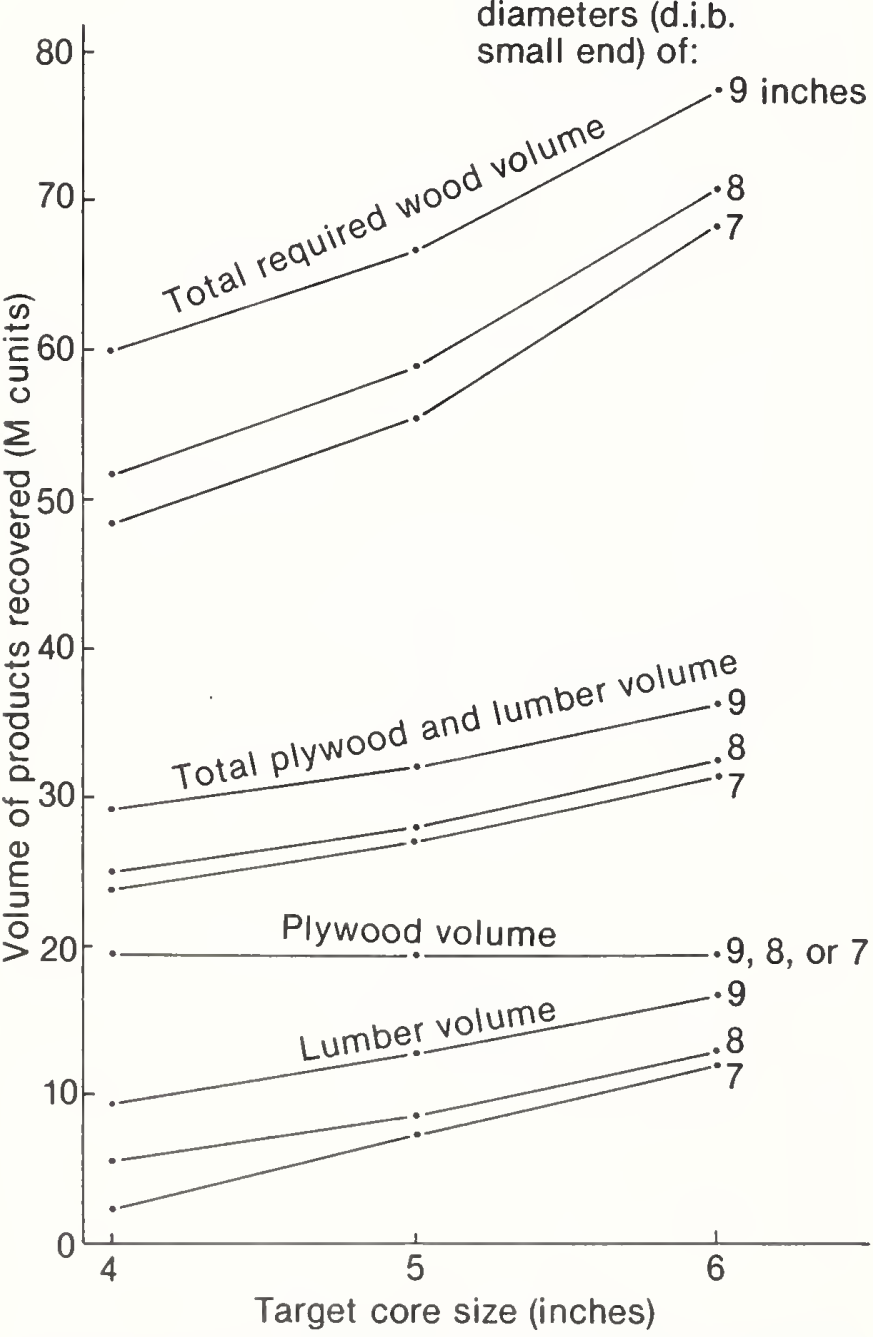

Figure 8.-Plywood and lumber volumes produced and total wood volume required on an annual basis. (Plywood is constant at 19,530 cunits, corresponding to $62.5 \mathrm{MM} / \mathrm{ft}^{2}$ (3/8-inch basis). converts these costs in terms of cost per cubic foot of wood equivalent. After analysis by the CFA program, prices and costs are then converted back into units characteristic of each product.

\section{Cost of Operation}

All costs are discussed in the order in which they are entered on the CFA program data sheet (Harpole 1978).

Selling expense.-The factor used represents the ratio of sales cost to gross sales, not an absolute value. The selling expense factor is assumed to remain constant for the analysis period.

Selling expense for plywood is composed of trade discounts of $5 \%$ and $3 \%$, a $2 \%$ cash discount on invoiced amount, and a $3 \%$ sales cost allowance on invoiced amount. The resulting composite factor is 0.1246 or $12.46 \%$.

Selling expense for lumber is composed of a $5 \%$ trade discount plus a $2 \%$ cash discount on invoiced amount. The resulting composite factor is 0.0690 or $6.9 \%$.

No selling expense factor is assumed for salable residue, because any such costs in the Black Hills region are built into chip and residue contracts.

Because the CFA program does not accommodate individual product cost analyses in integrated operations, the above factors were combined in a weighted average to reflect overall product selling expense. Representative market prices and the assumed product outputs for plywood, lumber, and salable residue were combined to derive a sales cost factor of 0.1125 based on total gross sales of all products.

Working capital.-Typical sources and uses of working capital are accounts receivable, timber sale and road deposits, accounts payable, and raw material and operating costs invested in goods-in-process or in unsold finished products inventory.

For this analysis, it was conservatively assumed that working capital requirements are equivalent to about 2 months' or 40 working days' production. For a base working year of 242 days, the computed working capital factor is 0.1653 .

Tax rate.-The federal income tax rate for this enterprise is assumed to be $48 \%$. South Dakota and Wyoming do not impose state corporate income taxes.

Discount rate.-The expected rate of return on investment is represented in the analysis by assumed discount rates. These rates are used to determine the present value of future cash flows included in the break-even analysis. As part of the analysis to determine limits on plant operating parameters, the discount rate is varied from a minimum value of $6 \%$, through an average value of $15 \%$, to a maximum value of $25 \%$.

Time span of CFA.-The time period considered in the CFA is 10 years, chosen for reasons explained in the paragraphs on depreciation.

Unit manufacturing costs.-For the plywood plant, these are variable costs, such as wood procurement costs and glue and chemical costs that vary directly with output; for the sawmill, only wood procurement 


\begin{tabular}{|c|c|c|}
\hline \multirow{2}{*}{$\begin{array}{l}\text { Material type (product volume) } \\
\text { Total volume (wood + bark) }\end{array}$} & \multicolumn{2}{|c|}{ 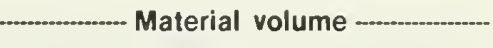 } \\
\hline & & $\begin{array}{l}6,386,445 \\
1,222,993\end{array}$ \\
\hline Total wood volume & & $5,163,452$ \\
\hline $\begin{array}{l}\text { Wood to plywood }{ }^{2} \\
\text { Minus: Green losses }\end{array}$ & $1,287,079$ & $4,215,760$ \\
\hline Lathe cores & 501,419 & $1,788,498$ \\
\hline $\begin{array}{l}\text { Green veneer } \\
\quad \text { Minus: Dryer shrink }\end{array}$ & & $\begin{array}{r}2,427,262 \\
102,108 \\
\end{array}$ \\
\hline $\begin{array}{l}\text { Dry veneer } \\
\text { Minus: Trim \& dry loss }\end{array}$ & & $\begin{array}{r}2,325,154 \\
372,024 \\
\end{array}$ \\
\hline Plywood (62.5 MM ft ${ }^{2}, 3 / 8$-inch basis) & & $1,953,130$ \\
\hline Wood to lumber (from logs) & & 947,693 \\
\hline $\begin{array}{l}\text { Minus: Chips } \\
\text { Saw kerf }\end{array}$ & $\begin{array}{r}469,579 \\
23,342 \\
\end{array}$ & 492,921 \\
\hline $\begin{array}{l}\text { Lumber, rough green untrimmed } \\
\text { Minus: End trim }\end{array}$ & & $\begin{array}{r}454,772 \\
26,629 \\
\end{array}$ \\
\hline Lumber, rough green trimmed & & 428,143 \\
\hline $\begin{array}{l}\text { Minus: Drying shrink } \\
\text { Planer, sander loss }\end{array}$ & $\begin{array}{l}29,991 \\
34,869\end{array}$ & 64,860 \\
\hline Lumber, dry dressed $(6,641,707 \mathrm{fbm})$ & & 363,283 \\
\hline Wood to lumber (from lathe cores) & & 501,419 \\
\hline Minus: Chips & 254,867 & \\
\hline Saw kerf & - & 254,867 \\
\hline $\begin{array}{l}\text { Lumber, rough green untrimmed } \\
\text { Minus: End trim }\end{array}$ & & $\begin{array}{r}246,552 \\
14,197 \\
\end{array}$ \\
\hline Lumber, rough green trimmed & & 232,355 \\
\hline $\begin{array}{l}\text { Minus: Drying shrink } \\
\text { Planer, sander loss }\end{array}$ & $\begin{array}{l}16,188 \\
18,929 \\
\end{array}$ & 35,118 \\
\hline Lumber, dry dressed $(3,605,326 \mathrm{fbm})$ & & 197,237 \\
\hline
\end{tabular}

\footnotetext{
${ }^{1} T o t a l$ values may be in error by 1 cubic foot because of rounding errors after multiplying index volumes (table A-5) by the "blow-up" factor (table A-7).

'Logs 8 inches and larger, d.i.b., peeled to a 4-inch core.
}

costs vary directly with output. In an integrated operation, wood procurement cost is shared between plywood, lumber, and salable residue.

The CFA program used in this analysis considers only one product per computer run, but this limitation is not critical, because diverse outputs like plywood, lumber, and residue can be analyzed simultaneously when computed on a cubic foot product basis. Table 16 has unit cost data for various levels of log procurement cost. The final unit cost figure includes a charge of $\$ 23.20$ per cunit of plywood for glue and chemicals, which translated into an equivalent of $\$ 9.87$ per cunit of composite product output.

Other variable costs. - These costs are mixtures of fixed and variable elements, but are predominantly variable. Labor, energy, and utilities are examples of these costs. In this analysis "other variable cost" categories for year 1 are as follows:

Plywood

Direct labor

Operating supplies

$\$ 930,286$

48,750

Association dues

37,500

Power-electric (from commercial sources)

Power-steam (from residue fuels)

178,560

128,414

Lumber, residue

$1,323,510$

128,668

Total of other variable costs

$1,452,178$

Fixed manufacturing costs.-Although regarded as constant regardless of output level, these costs can have some variable elements. However, for purposes of 
this analysis, they are considered joint costs dependent primarily on the rated capacity of the plywood/sawmill complex.

Costs in this category are maintenance, supplies and expenses, and mill supervision. Amounts for these fixed manufacturing costs are as follows:

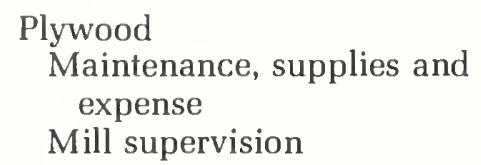

Lumber

\section{Total fixed manufacturing costs $\quad 249,393$}

Overhead costs.-Included are costs expected to vary as a constant proportion of facilities costs, such as insurance and taxes. Office and miscellaneous costs are also included in overhead costs.

Insurance is estimated to be $1.5 \%$ of total facilities capital investment. Taxes include ad valorem property taxes and other local assessments. Corporate income taxes are not considered here. Office costs are made up of staff salaries including the mill sales function, supplies, telephone, and travel expenses. Estimates of these costs are as follows:

\begin{tabular}{lr} 
Plywood & \\
Insurance & $\$ 297,284$ \\
Taxes, local & 16,951 \\
Office & 74,852 \\
Miscellaneous & 10,000 \\
\cline { 2 - 2 } & 399,087 \\
Lumber & 308,436 \\
\hline
\end{tabular}

Total overhead costs

707,523

Facilities costs.-These costs are made up of all investments necessary to provide physical resources for production. Items include costs for land, site preparation, buildings, engineering, processing machinery, mobile equipment, and other like expenses.

Table 17 shows the major capital expenditures necessary for the physical facilities. Included in addition to these costs are pre-start up charges for interest on capital during construction and for salaries of key personnel during the construction period. ${ }^{29}$

Physical facilities
Interest on capital (15\%)
Salaries

Total facilities costs

$$
\begin{array}{r}
\$ 9,909,450 \\
1,486,418 \\
116,776 \\
\hline
\end{array}
$$

$11,512,664$

It was assumed that all mobile equipment would be replaced after 5 years of use. The original capital cost of $\$ 250,000$ was increased to $\$ 367,332$ to cover an inflation rate of $8 \%$ annually for 5 years.

Depreciation.-Depreciation charges account for expiration of fixed assets. Harpole (1978) has excerpted data from the 1971 Revenue Act to illustrate ranges in the time periods allowed for depreciation of various capital assets. Land improvements typically are allowed a 20-year depreciation period, and buildings are allowed 45- or 60-year depreciation periods depending on type of building. Processing equipment for primary and secondary manufacturing of plywood, lumber, and particleboard is allowed a depreciation period of 8 to 12 years with an average of 10 years.

\footnotetext{
${ }^{29}$ These cost estimates as well as all others in this report are based on 1977 prices. A more recent estimate for cost of similar facilities, current as of mid-1979, is $\$ 20-25$ million. Personal com-

\begin{tabular}{|c|c|c|c|c|}
\hline $\begin{array}{c}\text { Stumpage } \\
\text { cost } \\
\text { (per M fbm (LS)) }\end{array}$ & $\begin{array}{c}\text { Stumpage } \\
\text { cost' } \\
\text { (per cunit, log scale) }\end{array}$ & $\begin{array}{c}\text { Stumpage } \\
\cos ^{2} \\
\text { (per cunit, plywood) }\end{array}$ & $\begin{array}{l}\text { Stumpage cost plus } \\
\text { glue and chemicals } \\
\text { (per cunit) }\end{array}$ & $\begin{array}{c}\text { Unit cost" } \\
\text { (per cunit of composite product) }\end{array}$ \\
\hline 130 & 57.85 & 153.04 & 176.24 & 75.002 \\
\hline 110 & 48.95 & 129.50 & 152.70 & 64.982 \\
\hline 90 & 40.05 & 105.95 & 129.15 & 54.962 \\
\hline 70 & 31.15 & 82.41 & 105.61 & 44.943 \\
\hline 50 & 22.25 & 58.86 & 82.06 & 34.922 \\
\hline 30 & 13.35 & 35.32 & 58.52 & 24.903 \\
\hline
\end{tabular}
munication from R. F. Baldwin, Camden, Tex.
}

Table 16._-Unit manufacturing costs (dollars) for Black Hills plywood, lumber, and chip mill

\footnotetext{
'Cost per M fbm (LS) $\times 0.445 \frac{M f b m(L S)}{\text { cunit, log scale }}$

${ }^{2}$ Cost per cunit log scale $\times 2.646 \frac{\text { cunit, log scale }}{\text { cunit, plywood }}$

${ }^{3}$ Cost per cunit plywood $+\$ 23.20 /$ cunit for glue and chemicals = unit cost in terms of plywood cubic volume.

“Cost per cunit plywood $\times 0.42556 \frac{\text { cunil, plywood }}{\text { cunit, composite product }}=$ unit cost in terms of total cubic volume of salable product.
} 
Table 17.-Capital investment (1977) (dollars) for plywood production facilities in the Black

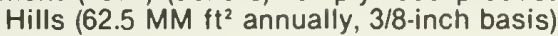

\begin{tabular}{lr}
\hline Land & 24,000 \\
Site preparation & 25,000 \\
Foundations & 411,200 \\
Buildings & $1,880,000$ \\
Utilities & $1,948,000$ \\
Plant equipment and machinery & $3,242,750$ \\
Miscellaneous and mobile equipment & 250,000 \\
Design and Engineering & 412,000 \\
Contingencies & 750,000 \\
Auxiliary sawmill, including kiln & 966,000 \\
\multicolumn{1}{c}{ Total facilities cost } & \\
& $9,909,450$ \\
\hline
\end{tabular}

Table 18 shows the flow of depreciation charges over the 10-year analysis period. In this analysis, site preparation, buildings, and mobile equipment were written off with straight line depreciation for the total period appropriate to each asset. Processing machinery is depreciated by the double declining balance method for the first 5 years, then switched to straight line depreciation for the remaining 5 years of its investment life. Accelerated depreciation in the early years of the capital investment assumes that benefits from the asset are greatest when it is new and that technical progress increases the risk of early obsolescence for machinery.

Investment tax credit.-This credit is incorporated into the feasibility analysis, because it is a currently available stimulus to investment. A credit of $10 \%$ of the cost of processing machinery and mobile equipment is shown below:
Plywood process equipment

Lumber process equipment

Mobile equipment

Total investment tax credit
$\$ 324,275$

75,300

25,000

424,575
Rising costs.-The CFA computer program was modified to enable subsequent users to enter estimated changes in prices and costs into updates of the analysis. To allow for rising costs, the wholesale price index was selected as an indicator of general cost levels for industry. This index is available from the U.S. Department of Labor, Bureau of Labor Statistics, and is also tabulated in the series on demand and price situation for forest products published by the USDA Forest Service (Phelps 1977). The years 1967 to 1976 were chosen as the base period. During this period the Wholesale Price Index rose from 100 to 183 . This increase is equivalent to a $6.95 \%$ compound annual interest rate. This rate was applied to estimated 1977 costs to compute future costs over the subsequent 10-year period.

\section{Revenues}

Cash revenue was projected from the sale of plywood, stud lumber, chips, and sawdust. While plywood revenues are the focal point of this report, economic feasibility also depends on sale of these other products.

Prices were assumed for lumber and salable residue, and then were used to determine the plywood price that would be needed to break even, with all costs considered. Lumber and residue prices were assumed to increase at a $7.2 \%$ annual rate based on data for 1967 to 1976 (Phelps 1977).

Base prices for 2- by 4-inch stud lumber were the average prevailing mill prices in 1977 and 1978. Chip and sawdust prices, oven dry (o.d.), were based on 1978 levels at rail loading points in the Black Hills. Base prices used were as follows:

\section{Product and units}

2- by 4-inch stud lumber

(M fbm (LT))

Chips, (o.d. tons)

Sawdust, (o.d. tons)

\section{Product \\ dollars/unit}

175.00

17.50

4.00
Cubic volume price

dollars/cunit

320.00

21.00

4.80
These cubic volume unit prices, multiplied by the cubic volume output of each respective product, give total revenue from all nonplywood production.

The typical definition of breakeven point is that level of business operation where total revenues and total expenses are equal. Part of total expenses is the implicit alternative cost of capital and operating funds that could have been invested elsewhere. This alternative cost is covered by the specified rate of return. Thus, breakeven plywood price, as used here, is the amount per thousand square feet required to make total revenue match total costs plus the specified rate of return.

One additional factor of importance in computing break-even plywood price is the mix of plywood grades and thicknesses. However, this price, as computed by the CFA program, must be in terms of dollars per hun- 
Table 18.-Depreciation schedule (dollars) for plywood plant and associated auxiliary lumber/chip mill

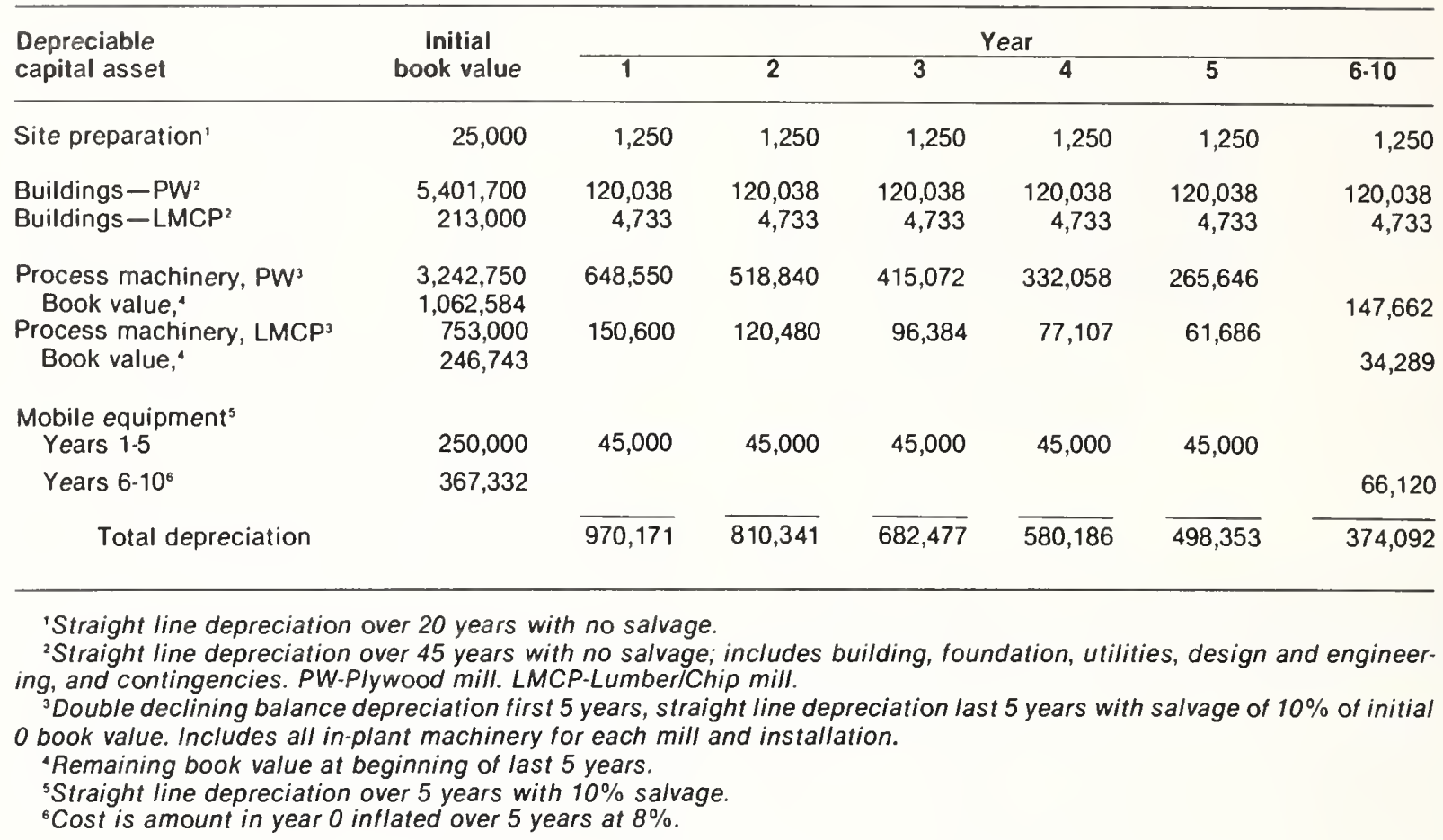

dred cubic feet of plywood, regardless of grade or thickness. Further analysis is needed to break down the composite cubic-foot price into a representative mix of plywood grades and thicknesses. In this study, the composite price was based on five thicknesses of C-D-X grade plywood. Although other grades of plywood were discussed as good production opportunities, only commodity grades were used for this economic analysis, because their market prices can be more accurately established. Any error resulting from this assumption would be on the conservative side. Output proportion and average mill price for the five thicknesses included in the analysis are shown below:

$\begin{array}{ccc}\begin{array}{c}\text { C-D-X } \\ \text { thickness }\end{array} & \begin{array}{c}\text { Proportion } \\ \text { of output } \\ \text { percent }\end{array} & \begin{array}{c}\text { Assumed } \\ \text { mill price } \\ \text { inch }\end{array} \\ \text { 5/16, 3 ply } & 1.2 & 160 \\ \text { 3/8, 3 ply } & 13.9 & 164 \\ \text { 1/2, 4 ply } & 68.7 & 223 \\ \text { 5/8, 5 ply } & 12.8 & 263 \\ \text { 3/4, 5 ply } & 3.4 & 327\end{array}$

These were used to establish the price spread between thicknesses in computing prices for individual plywood thicknesses.

\section{Profitability}

The values given in the preceding discussion of costs of operation are assumed to be base figures for the CFA. In addition, for the base run, log cost is assumed to be $\$ 70$ per thousand board feet, Scribner log scale, and internal rate of return is $15 \%$. CFA output for these assumed values is shown in table 19. As an example of how values in table 19 are computed, table 20 shows the flow of computations necessary to get an after-tax net cash flow of $\$ 2,199,782$ for year 1 .

Table 19 shows that the break-even unit price must average $\$ 180.48$ per hundred cubic feet of composite product. Lumber mill value is assumed to be $\$ 175$ per thousand board feet, and chip and sawdust mill value is assumed to be $\$ 17.50$ and $\$ 4.00$ per o.d. ton, respectively. Mill realization for $1 / 2$-inch C-D-X sheathing must then be $\$ 141.41$ per thousand square feet $\left(\mathrm{M} \mathrm{ft}^{2}\right.$, surface area basis). Required mill realizations for the remaining C-D-X thicknesses are computed by applying market price spreads to the $1 / 2$-inch C-D-X realization. Results are shown in the following tabulation:

$\begin{array}{ccr}\begin{array}{c}\text { C-D-X } \\ \text { thickness } \\ \text { inch }\end{array} & \begin{array}{c}\text { Price spread factor } \\ \text { price, given thickness }\end{array} & \begin{array}{r}\text { Plywood } \\ \text { mill realiza } \\ \text { dollars/M }\end{array} \\ \begin{array}{ccc}\text { price, } 1 / 2 \text {-inch thickness } \\ \text { surface area }\end{array} \\ 5 / 16 & 0.717 & 101.46 \\ 3 / 8 & 0.735 & 104.00 \\ 1 / 2 & 1.000 & 141.41 \\ 5 / 8 & 1.179 & 166.77 \\ 3 / 4 & 1.466 & 207.36\end{array}$

To estimate market break-even prices, freight costs as shown in table 7 plus other handling charges must be added. 


\section{ALTERNATIVE OPERATING FORMATS}

The preceding analysis portrayed operation of an integrated plywood plant, sawmill, and chip mill facility. All input and output factors described previously were set at values considered reasonable based on late 1977 and early 1978 price levels. Break-even prices computed under these circumstances indicated economic feasibility, given current market conditions. However, because market conditions in the forest products industry, and, therefore, production factors, vary widely over time, the effect on break-even prices of changes in selected input or output factors needs further investigation.

\section{Effect on Break-even Price}

Given the input factor values used in the previous sections, the effects of a change in various production costs and a change in stud price on the breakeven price for plywood were computed (fig. 9). For example in A, an increase in labor cost of $20 \%$ would raise break-even price from about $\$ 141$ to about $\$ 147$ per thousand square feet area basis. The slope of the graph line for a specific factor indicates the sensitivity of breakeven price to percent changes in the responsible factor-the steeper the slope, the greater the sensitivity.

In example B (fig. 9), the graph line for stud price shows that a $40 \%$ decrease from $\$ 175$ to $\$ 105$ per thousand board feet would result in a rise in breakeven price for $1 / 2$-inch C-D-X plywood to about $\$ 152$. Typically, however, the prices of sheathing plywood and studs move in the same direction at the same time, because they are complementary commodities in the housing construction materials market.

All relationships are linear except for changes in "Production below capacity." If the plant has to operate at $20 \%$ or $40 \%$ below capacity, for example, fixed costs are spread over lower output and, consequently, the break-even price must rise rapidly for revenues to cover expenses.

Total costs affect break-even price most dramatically and give a general idea of inflationary effects on a plant of this size. Because the capacity of this plant is the size of smaller plywood plants currently operating, fixed costs are a higher proportion of the total. Increases in general cost levels, therefore, can be expected to impact this plant more severely than a larger operation.

The relative lack of sensitivity of break-even price to energy costs is noteworthy. Energy costs are not as high as they otherwise might be, because it was assumed that the plant would depend on its own residue for process steam. Such residue was valued at current salable residue prices or at zero price depending on

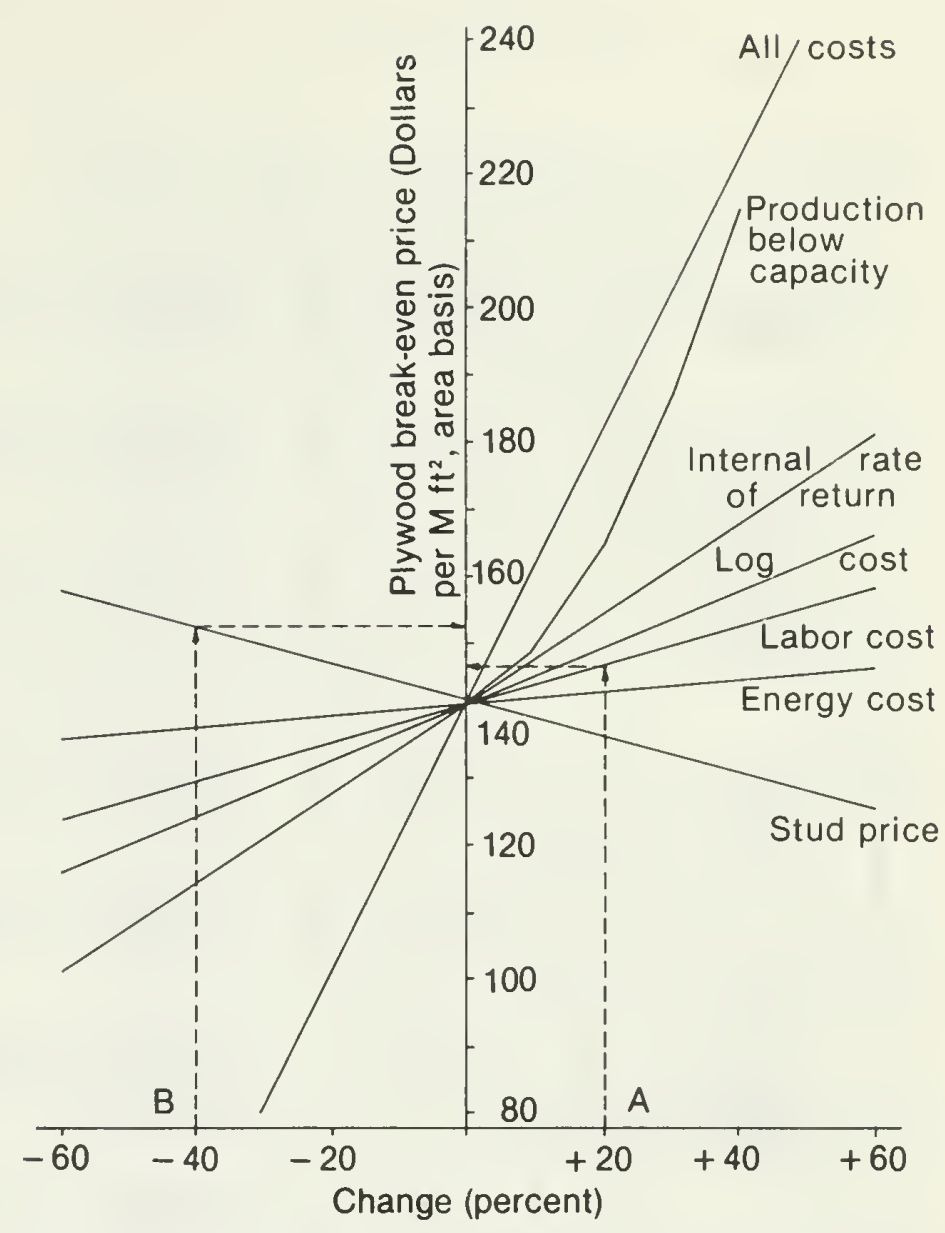

Figure 9.-Sensitivity of break-even price, 1/2-inch C.D.X plywood, area basis, to percent changes in selected cost and plant opera. tion factors.

alternative uses. Therefore, although electricity is purchased commercially, total residue-based energy costs do not form a large proportion of total costs.

\section{Effect on Raw Material Need}

Although not discussed here in detail, log cost is sure to receive serious management attention. For this plant it was conservatively assumed that 8-inch and larger blocks would be peeled to a 4 -inch core. Instead, management could decide, for example, to peel 7 -inch, or even 6-inch and larger logs, to a 3 -inch core. The rationale might be that because blocks of this size are generated from multiproduct sales, they might better go into plywood than lumber, and thus reduce the total mill log supply required to produce annually $62.5 \mathrm{MM} \mathrm{ft}^{2}$ (3/8-inch basis) of plywood. In this case, rather than produce lumber as the only secondary product, cores might be treated with a suitable preservative and sold for fence posts. Logs not suitable for peeling might be sawn for lumber, or chipped for pulp or fuel, depending on relative needs and prices. 


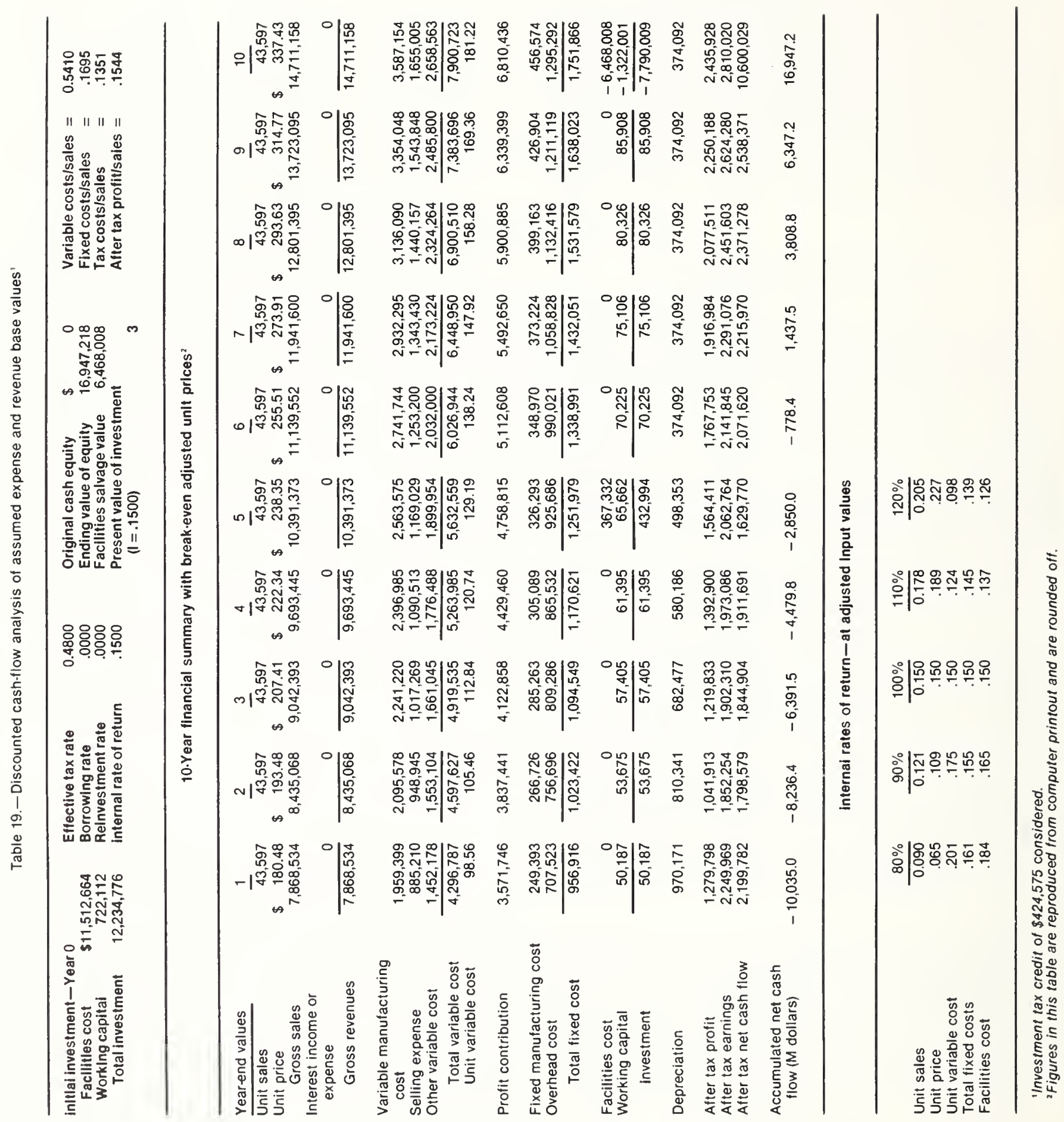




\section{LITERATURE CITED}

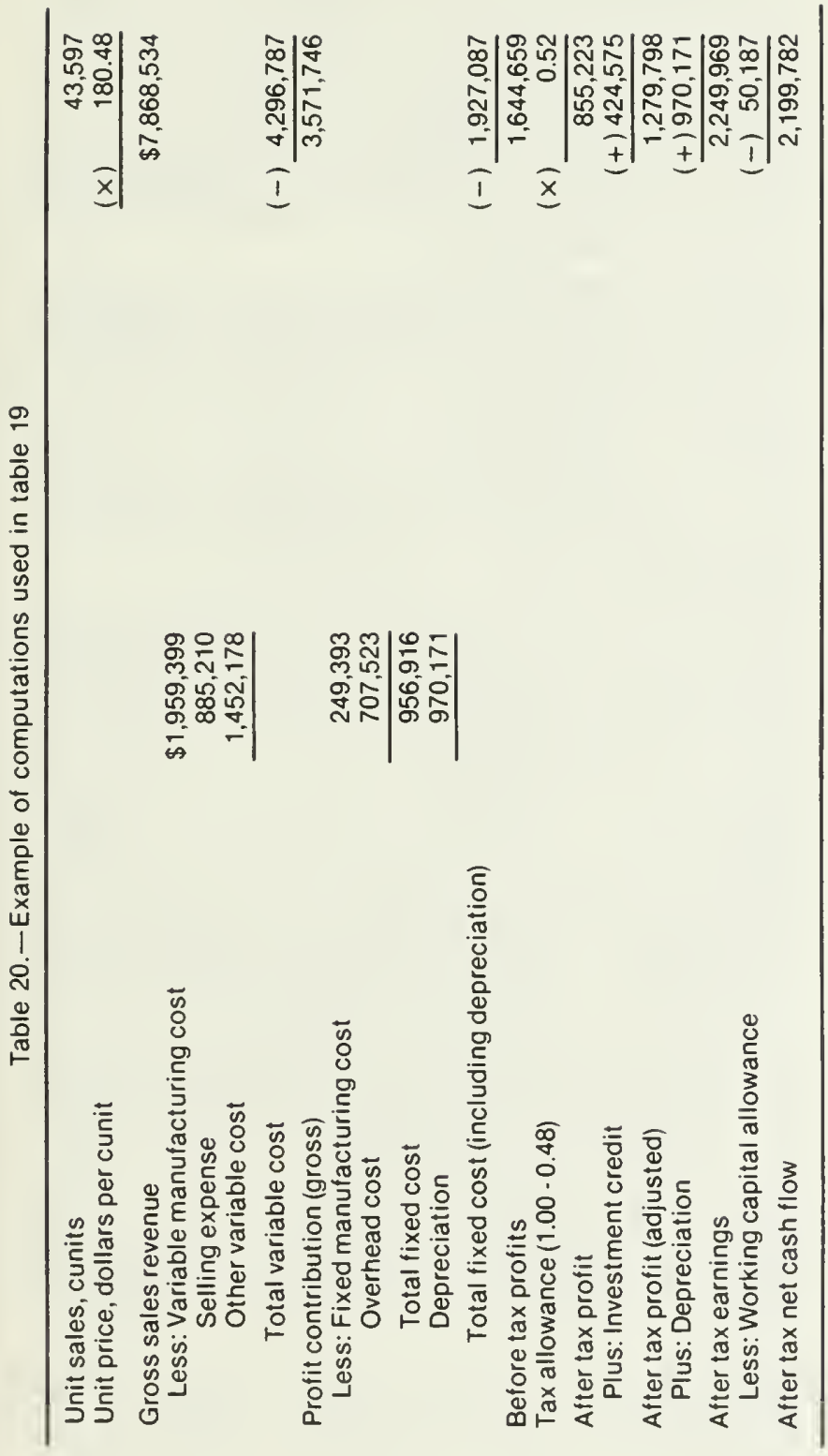

American Plywood Association. 1974. U.S. Product Standard PS 1-74 for construction and industrial plywood with typical APA grade-trademarks. $35 \mathrm{p}$. American Plywood Association, Tacoma, Wash.

American Plywood Association. 1976. Plywood end-use marketing profiles 1976-1978. 44 p. American Plywood Association, Tacoma, Wash.

American Plywood Association. 1977a. APA 303 plywood siding grades and finishing. American Plywood Association Form B8301277. American Plywood Association, Tacoma, Wash.

American Plywood Association. 1977b. Geographical analysis of plywood shipments 1976-western, southern, and inland regions. Three Vol., American Plywood Association, Tacoma, Wash.

American Plywood Association. 1978a. Manufacturing specifications for APA 303 series specialty siding. American Plywood Association Form B840178. American Plywood Association, Tacoma, Wash.

American Plywood Association. 1978b. 303 plywood siding: Grades \& finishing. American Plywood Association Form B830C. American Plywood Association, Tacoma, Wash.

American Plywood Association. 1980. Introducing APA rated sheathing. American Plywood Association Form E435B. American Plywood Association, Tacoma, Wash.

Anderson, L. O., and T. B. Heebink. 1964. Wood crate design manual. U.S. Department of Agriculture, Agriculture Handbook 252, 131 p. Washington, D.C.

Anderson, Robert G. 1977. Long term forecast of plywood demand 1977-1986. American Plywood Association Economic Report E23. 23 p. American Plywood Association, Tacoma, Wash.

Baldwin, Richard F. 1977. Southern pine plywood-from $0 \%$ in ' 64 to $33 \%$ of U.S. output in '76. Forest Industries 104(3):40-3.

Forest Industries. 1977. Directory of panel plantsUSA and Canada. Forest Industries 104(3):94-115.

Forest Industries. 1979. Waferboard continues to generate interest. Forest Industries 106(5):17.

Gregory, G. Robinson. 1972. Forest Resource Economics. 548 p. The Ronald Press Co., New York.

Harpole, George B. 1978. A cash flow computer program to analyze investment opportunities in wood products manufacturing. USDA Research Paper FPL-305, 25 p. Forest Products Laboratory, Madison, Wisc.

Hunt, Douglas L., and Richard O. Woodfin, Jr. 1970. Estimate of dry veneer volume losses in Douglas-fir plywood manufacture. USDA Forest Service Research Note PNW-137, 10 p. Pacific Northwest Forest and Range Experiment Station, Portland, Oreg. 
Krier, John P., and Bryan H. River. 1968. Bark residues: A model study for quantitative determination. Bulletin 35, Montana Forest and Conservation Experiment Station, School of Forestry, University of Montana, Missoula, Mont.

Lambert, Herbert G., tech. ed. 1977. Directory of the forest products industry. 665 p. Miller-Freeman Publications Inc., San Francisco, Calif.

Markstrom, Donald C., William F. Lehmann, and J. Dobbin McNatt. 1976. Technical feasibility of producing particleboard from Black Hills ponderosa pine. USDA Forest Service Research Paper RM-173, 10 p. Rocky Mountain Forest and Range Experiment Station, Fort Collins, Colo.

Mueller, Lincoln A., and J. L. Kovner. 1967. Lumber production from selected Black Hills ponderosa pine. USDA Forest Service Research Paper RM-31, 20 p. Rocky Mountain Forest and Range Experiment Station, Fort Collins, Colo.

Myers, Clifford A. 1963. Taper table for pole-size Ponderosa pines in Arizona and New Mexico. USDA Forest Service Research Note RM-8, 2 p. Rocky Mountain Forest and Range Experiment Station, Fort Collins, Colo.

Phelps, Robert B. 1977. The demand and price situation for forest products 1976-1977. U.S. Department of Agriculture, Miscellaneous Publication No. 1357, 95 p. U.S. Department of Agriculture, Washington, D.C.

Rand McNally and Company. 1963. Trading Area Manual-A supplement to the Ranally Trading Area map of the United States. Rand McNally and Co., Chicago.

Setzer, Theodore S., and Michael K. Barrett. 1977. Western South Dakota timber production and mill residues, 1974. USDA Forest Service Research Note INT-233, 5 p. Intermountain Forest and Range Experiment Station, Ogden, Utah.

South Dakota Dep. of Game, Fish and Parks. 1974. South Dakota forest products manufacturing directory. 31 p. South Dakota Department of Game, Fish and Parks, Division of Forestry, Pierre, S. Dak.

USDA Forest Service. 1977. Final environmental statement timber management plan for the Black Hills National Forest. 218 p. and appendices. U.S. Department of Agriculture, Forest Service, Rocky Mountain Region, Denver, Colo.
U.S. Department of Agriculture and U.S. Department of Interior. 1967. Black Hills area resources study. 225 p. U.S. Department of Agriculture and U.S. Department of Interior, Washington, D.C.

U.S. Department of Agriculture, Forest Products Laboratory. 1974. Wood Handbook: Wood as an engineering material. U.S. Department of Agriculture, Agriculture Handbook 72, revised, 426 p. Washington, D.C.

U.S. Department of Commerce, Bureau of the Census. 1978a. Current Industries Report Series MA-24 H (77-1), 6 p. U.S. Department of Commerce, Bureau of the Census, Washington, D.C.

U.S. Department of Commerce, Bureau of the Census. 1978b. Statistical Abstract of the United States, 1057 p. U.S. Department of Commerce, Bureau of the Census, Washington, D.C.

Van Deusen, James L. 1967. Conversion of tree heights in logs to heights in feet: Black Hills Ponderosa pine. USDA Forest Service Research Note RM-94, 2 p. Rocky Mountain Forest and Range Experiment Station, Fort Collins, Colo.

Williston, Ed M. 1976. Lumber manufacturing: The design and operation of sawmills and planer mills. 512 p. Miller Freeman Publications Inc., San Francisco, Calif.

Woodfin, Richard O., Jr. 1960. Taper in Black Hills ponderosa pine sawtimber trees. U.S. Department of Agriculture, Forest Service, Rocky Mountain Forest and Range Experiment Station, Research Note No. 52, 3 p. Fort Collins, Colo.

Woodfin, Richard O. 1973. Wood losses in plywood production-Four species. Forest Products Journal 23(9):98-106.

Woodfin, Richard O., Jr., and W. Y. Pong. 1972. Dry veneer volume losses in production of red and white fir plywood. USDA Forest Service Research Note PNW-191, 12 p. Pacific Northwest Forest and Range Experiment Station, Portland, Oreg.

Wyoming Department of Economic Planning and Development. 1974. Wyoming timber industries directory. 28 p. Wyoming Department of Economic Planning and Development, Cheyenne, Wyo.

Yerkes, Vern P., and R. O. Woodfin, Jr. 1972. Veneer recovery from Black Hills ponderosa pine. USDA Forest Serv. Res. Pap. RM-82, 23 p. Rocky Mountain Forest and Range Experiment Station, Fort Collins, Colo.

Young, Charles E. 1978. Young's Forecast. Wood 83(12):14 


\section{APPENDIX}

\section{MARKETS}

\section{Plywood Properties Important in Marketing}

Various plywood applications require different panel characteristics or different combinations of characteristics. The following summary describes some of the more important properties of sheathing and associated types of plywood related to particular end uses. $^{1}$

Stiffness.-The ability of a panel to resist deformation in the plane of the panel results from the inherent elasticity of the wood and the panel thickness. Stiffness is of primary importance in such applications as roof sheathing, subflooring, combination floor, wall sheathing, boxes, pallets, and air cargo containers.

Bending strength.-The ability of a panel to support a load without breaking. This characteristic is significant in such applications as sheathing, subflooring, combination floor, wall sheathing, boxes, pallets, and air cargo containers.

Rigidity.-The ability of a panel to resist racking, or deformation "out-of-square." This property is important when the plywood is used as subflooring or wall sheathing and in boxes and pallets.

Weight.-Because panels manufactured from different species vary considerably in weight, this significantly affects ease of handling, dead loads of structures, and tare weight of packaging. Weight becomes important in uses such as roof sheathing, combination flooring, and air cargo containers.

Thermal insulation.-The ability of the material to restrict the flow of heat. This characteristic is particularly important for wall and roof sheathing.

Workability.-The ease with which various woods can be worked with hand or machine tools in such operations as sanding, sawing, grooving, etc. Workability of plywood is very significant when plywood is used in applications such as cabinets, boxes, and air cargo containers.

Fastening strength.-The ability of the plywood to hold mechanical fasteners, such as nails or screws. Fastener-holding capacity is important in all plywood applications but is especially critical in van linings, boxes, pallets, and air cargo containers.

Color.-The general appearance of a panel as to whether it is light or dark and the overall effect of the grain pattern caused by the growth rings. A light

'Information in the following titled paragraphs is taken from F. F. Wangaard et al. (1971). Potential markets for plywood made from Rocky Mountain ponderosa pine and Engelmann spruce. Unpublished Report, Department of Forest and Wood Science, Colorado State University, Fort Collins, Colo. (On file at Rocky Mountain Forest and Range Experiment Station, Fort Collins, Colo.) uniform color is usually considered to be desirable for plywood, even when it serves no specific functional purpose.

Integrity of surface.-The degree to which defects (knots, knotholes, bark pockets, and pitch pockets) are found in the face plies of plywood. This characteristic is most important when plywood is used for underlayment, combination floor, siding, combination siding, and van linings, where holes or voids in the surface may show through coatings or coverings or make the panel more subject to mechanical damage or weathering.

Surface hardness. - The resistance of the wood to abrasion and puncture. This property is significant in plywood used for underlayment, combination flooring, siding, combination siding, van lining, boxes, pallets, and air cargo containers.

Dimensional stability.-The ability of a panel to maintain the same dimensions through fluctuations in climate or moisture content. This property is most important for plywood used for underlayment, combination flooring, siding, and combination siding. Dimensional stability is slightly less important for roof sheathing, subflooring, wall sheathing, and van linings.

Weathering.-Warping and change in color, roughening, or checking of the surface caused by exposure to the elements. Because of plywood's exceptional dimensional stability, the problem of cupping and twisting from uneven stresses on the face and back of solid wood are largely eliminated. However, surface checking and roughening is often a problem. Good weathering characteristics are critical in siding and combination siding, but considerably less important in covered sheathing, boxes, pallets, and air cargo containers.

Painting quality.-This property reflects how well a material will take paint or stain and the frequency of maintenance required. Painting characteristics of plywood are similar but usually somewhat inferior to those of solid lumber of the same species. It is extremely important in considering the use of plywood for siding and combination siding, but not for sheathing and other "hidden" structural applications.

Gluing quality.-The ability of the wood to form good glue bonds with other structural elements over a wide range of glue types and gluing conditions. It is important in using plywood for subflooring, underlayment, and combination flooring.

Appearance.-The general visual characteristics of the plywood panel. Appearance plays an important role in utilization of panels for siding and combination siding.

Acoustical insulation.-The ability of the material to restrict sound from passing through it. It is an important consideration in selecting plywood panels for wall sheathing, siding, and combination siding. 


\section{Applications in Residential Construction}

Roof sheathing.- The most critical property of roof sheathing is stiffness. In this market, ponderosa pine plywood would compete mainly with plywood made from Douglas-fir and southern pine, which have the highest strength properties of any commercial softwood plywood species. Code standards for roof sheathing specify the minimum strength and stiffness required for a given span. In many cases, ponderosa pine plywood would be able to satisfy the minimum requirements and, at a given thickness, could be used interchangeably with Douglas-fir or southern pine, although its strength and stiffness may be less. ${ }^{2}$ It is common practice for builders to use plywood roof sheathing thicker than required by building codes to provide an additional measure of stiffness desired by roofing applicators. Because thickness contributes more to stiffness than species, 1/2-inch ponderosa pine plywood roof sheathing may not only be acceptable under the code, but also about equally acceptable to builders when compared with Douglas-fir or southern pine. As an example, ponderosa pine 1/2-inch sheathing has an Identification Index ${ }^{3}$ of 24/0, while 1/2-inch sheathing of Group 1 species like Douglas-fir has an Identification Index of $32 / 16$. However, the most common roof joist spacing in light frame construction (housing) is 24 inches, no matter which plywood group is applied as sheathing. Subject to local building code restrictions and builder and consumer acceptance, ponderosa pine 1/2-inch plywood sheathing may be competitive with plywood sheathing of higher groups on an equal thickness basis.

Subflooring.-Stiffness and bending strength are the most important properties for subflooring, with rigidity, nail holding ability, dimensional stability, and gluing ability also rated as important characteristics. On the basis of physical properties, the suitability of species for subflooring follows the same general principles as for roof sheathing: Douglas-fir and southern pine have the highest ratings with ponderosa pine falling below western hemlock and above white fir and Englemann spruce. For a plywood species to be accepted in the flooring market, it must be suitable for

\footnotetext{
2Personal communication from R. F. Baldwin, Camden Tex. As of midyear 1979, the Industry Standard Committee of the American Plywood Association were considering an amendment to Product Standard 1.74 (American Plywood Association 1974). The amendment allows marking 1/2-, 5/8-, and 3/4-inch C-C-X, C-D, and Structural panels of Group 3 woods with the same Identification Index (Reference footnote 3 in appendix) as Group 1 woods if they are manufactured 1/32-inch thicker than standard nominal thickness and if they have 1/6-inch thick minimum face and back plies. This amendment, if accepted, would assist acceptance of ponderosa pine plywood in applications where the Identification Index for sheathing panels is specified.

3/dentification Index or Span Rating (American Plywood Association 1974) serves as an indicator of allowable roof and floor spans for which a particular plywood panel is mechanically suited. For example, in an Identification Index of $48 / 24$, the $48 \mathrm{in}$ dicates that when used for roof sheathing, the panel may have supports spaced up to 48 inches apart, center to center; the $24 \mathrm{in}$ dicates that the panel may be used for structural floors with supports spaced up to 24 inches apart, center to center.
}

spanning at least 16 inches, the most usual joist spacing. The APA has found that about $80 \%$ of plywood subfloors are $1 / 2$-inch thick. Underlayment in double floor systems is usually 5/8-inch. However, the major trend in flooring systems has been toward concrete slabs and single layer wood floors instead of toward double floor systems. ${ }^{4}$

Underlayment.-It is important for underlayment plywood to have integrity of surface, surface hardness, dimensional stability, and gluing ability. Because floor coverings are applied directly to the underlayment, the face of the plywood must be free of voids and resistant to puncture. Veneer of C Plugged or better grade may be suitable for face plies in ponderosa pine underlayment. Also of importance is the contrast in hardness between early and late wood (grain pattern) which may show through thin flexible floor coverings. Ponderosa pine has less grain contrast than either Douglas-fir or southern pine and might be preferred for that reason.

Combination floor.-This application is often referred to as a single layer floor system because it is one sheet of plywood which serves the dual function of subfloor and underlayment. The important properties for this use are stiffness, bending strength, light weight, integrity of surface, surface hardness, and gluing ability. Although Douglas-fir is rated as the best species because of its stiffness, strength, and surface integrity, ponderosa pine of 5/8-inch thickness can be used over 16-inch spans. With more than $90 \%$ of the floor joists in single-family and multi-family homes having a 16-inch span, ponderosa pine plywood should be competitive in this market if it satisfies the other requirements for subflooring and underlayment.

Wall sheathing.-Physical requirements for wall sheathing are less demanding than for roof sheathing or flooring. As a result, the market potential for woods of lower strength and stiffness, such as ponderosa pine, is greater. Specifications for wall sheathing are established on the basis of minimum requirements for specific stud spacings. A 5/16-inch ponderosa pine panel carries an index of 16/0, well over the minimum $12 / 0$ index required for 16-inch stud spacing. For 2- by 4 -inch or 2-by 6-inch studs spaced 24 inches o.c. ${ }^{5}$ the panel identification index can range from $16 / 0$ to $32 / 16$, depending on panel thickness and construction.

Siding.-The most important properties for siding are integrity of surface, surface hardness, dimensional stability, weathering, painting ability, and appearance. Of the species considered in this study, white fir, Douglas-fir, spruce, and hemlock were rated as the most acceptable species. Appearance, which is prob-

\footnotetext{
4Personal communication from Robert G. Anderson, Marketing Group, American Plywood Association, Tacoma, Wash., and personal communication from J. L. Bowyer, Department of Forest Products, College of Forestry, University of Minnesota, St. Paul, Minn.

${ }^{3}$ The distance from the center of one stud to the center of the next stud is 24 inches o.c. (on center). For more information on panel index and wall sheathing, read the American Plywood Association Tacoma, Wash., publications A30, Plywood Sheathing for Walls and Roofs, and W405, Mod 24 Building Guide. Application Data For 24-inch Framing.
} 
ably the most important property, is almost entirely dependent on individual tastes, and an adequate rating system for appearance has not been established. It may be possible to develop a siding product from ponderosa pine plywood by taking advantage of the rustic appearance of knotty veneer. Two basic types of plywood siding offer either textured veneer surfaces for painting or staining or smooth medium density overlay faces (MDO grade) for painting. Any commercial softwood species is technically acceptable for plywood siding material, subject to proven durability under exterior exposure and appropriate surface treatment.

Combination siding.-This type of siding combines the important technical functions of both siding and sheathing. Although ponderosa pine is rated lower for this use than some other species because of its lower strength values, there are no standards or specifications which would restrict the use of ponderosa pine in single wall construction. A major reason for significant increases in demand for combination siding has been the modular home concept, where a single panel of plywood serving as both a sheathing and siding material can provide the additional stiffness required in transportable units. There is still a problem of gaining building code acceptance for the single wall system in some areas as well as convincing builders that a separate sheathing material is not necessary. These attitudes should change as the public becomes more aware of the technical acceptability of this system.

The ability of ponderosa pine to penetrate this market depends largely on the ingenuity of producers in developing attractive siding products.

\section{Some Industrial Applications}

Van interiors.-Although there are no standard specifications for plywood used as the interior lining of truck vans, most of the grades used are A-D, B-C, and A-C. Each van manufacturer establishes its own standards. In some cases, plywood is also used as a floor covering in vans. Important physical characteristics for van interiors are fastener holding capability and surface hardness. All plywoods are rated in approximately the same range for these properties.

Plywood overlaid with fiberglass or metal is being used more often in this application. This material is also important in the construction of marine cargo containers. Ponderosa pine plywood would be an excellent substrate for these overlays.

Because of the high grade surface veneer required, it might be difficult to sell ponderosa pine plywood that is not overlaid for interior lining material. However, a potential may exist for van lining because of the lighter weight of pine plywood.

Boxes and crates.-Ponderosa pine plywood belongs to a group of species with the following properties: lightness in weight, freedom from splitting when nailed, moderate nail holding capacity, and fairly soft (Anderson and Heebink 1964). One of the main reasons for using such plywood for boxes and crates is that it is stronger and more durable than lumber, but this ad- vantage may be offset in some cases by the lower cost of lumber. Although penetration of plywood into the container market has been slow, it is increasing, and pine plywood could be in a particularly good position to supply an increasing proportion of this market.

Pallets.-Softwood plywood is increasingly used in pallet production, but substantial price differential over alternative materials largely limits its use to bin pallets and other specialized types. For example, an oak lumber pallet costs about one-third as much as a plywood pallet of comparable size and strength. Pallets, therefore, do not appear to offer a particularly promising market for ponderosa pine plywood, but the large size of the pallet industry means that ponderosa pine plywood might have specialized uses.

Air cargo containers.-Because light weight is a critical factor for this use, ponderosa pine plywood might be rated as one of the most suitable species. However, the American Plywood Association, after studying this application, feels that plywood does not have a good opportunity in this use. ${ }^{6}$

\section{APA 303 Siding Specifications}

APA siding is produced in four classes, based on number of panel face patches permitted, as shown below (American Plywood Association 1978a):
Class

303-0

303-6

$303-18$

$303-30$

\section{Face patches}

(Special Series)

none

6 maximum

18 maximum

30 maximum
Within each class there are provisions for different grades.

The characteristics of the four grades for the Special Series 303-0 class, which differ from those for the other three classes, are shown below (American Plywood Association 1978b):

\section{Class and grade}

303-OC

303-OL

303-NR

303-SR

\author{
Description \\ Clear \\ Overlaid (e.g., medium density \\ overlaid siding) \\ Natural rustic (e.g., permits \\ open knotholes) \\ Synthetic rustic (e.g., permits \\ natural-defect shaped \\ synthetic repairs)
}

Within each of the other three classes, the following three grades may be designated:
$-W$
$-S$
-S/W

\footnotetext{
'Personal communication from Robert G. Anderson, Marketing Group, American Plywood Association, Tacoma, Wash.
} 
Specifications for the APA "303" series siding include, but are not limited to, permissible levels for knots, knotholes, patches, splits, shims, and voids (American Plywood Association 1977a). The size and number of knots in C-grade ponderosa pine veneer may limit the class and grade of siding panels that could be manufactured in the Black Hills. However, APA "303-NR and -SR (rustic)" panels are permitted to have tight or pin knots up to $11 / 2$-inches in maximum size and no limit in number. Also, APA "303-30-S and S/W" grades permit tight knots of $11 / 2$ inches maximum, and pin knots of $3 / 8$ inch maximum. Patches are permitted in all grades except "Special Series 303."

\section{TIMBER RESOURCE}

\section{Black Hills National Forest Timber Classes}

Timber classes specified in the current 10-year Timber Management Plan of the Black Hills NF are described below, along with a concise statement of the probable silvicultural treatment for each timber class. ${ }^{7}$

P21 is an uneven-aged stand of ponderosa pine sawtimber in the standard component with an inadequately stocked pine understory. This stand has 60 to 120 square feet of growing stock basal area. Enter this stand with the first cut of the three-cut shelterwood system to establish regeneration.

PB1 is a two-storied ponderosa pine stand in the standard component. This stand has $60-120$ square feet of growing stock basal area. It has an adequately stocked sawtimber overstory and a fully stocked pine understory. The overstory will be removed in two cuts to minimize damage to the established understory. Because of the size of the understory, it is assigned a managed age of 10 . The second cut (seed cut) will be made in the overstory.

P31 is an overstocked, uneven-aged stand of ponderosa pine sawtimber in the Standard Component. This stand has more than 120 square feet of growing stock basal area, which requires immediate entry. This entry will be by a multiproduct cut to reduce density. Trees will be cut from all diameter classes to a growing stock level (GSL) of 80.

P61 is an overstocked ponderosa pine poletimber stand in the Standard Component. This stand has in excess of 120 square feet of growing stock basal area. Enter this stand with an intermediate cut to a GSL of 80.

PA1 is a two-storied ponderosa pine stand in the Standard Component. This stand has less than 60 square feet of growing stock (all live trees $\geqslant 5$ inches d.b.h.) basal area. It has a sparse sawtimber overstory age 150 and a fully stocked pine understory. The overstory will be removed in two cuts to minimize damage to the established understory. Because of the size of the understory, it is assigned a managed age of 10.

'Timber Management Plan, Black Hills National Forest. 1977. Unpublished document on file at Rocky Mountain Forest and Range Experiment Station or available from Supervisor's Office, Black Hills NF, Custer, S. Dak.
SC1/SB1: SC1 is a spruce-pine mix sawtimber stand in the Standard Component, and SB1 is a pine-spruce sawtimber stand in the Standard Component. Enter these stands, cutting in all size classes to a GSL of 90 to retain the uneven-aged character of these stands. GSL's of 120 + are acceptable, because beetle populations are not a problem in these stands.

WZS is a spruce-pine sawtimber stand in the Special Component. Cut in all size classes to a GSL of 90 to retain the uneven-aged character of this stand. GSL's of $120+$ are acceptable, because beetle populations are not a problem in these stands.

TZB/TZN: TZB is an uneven-aged ponderosa pine sawtimber stand outside the Norbeck Wildlife Preserve Special Component. TZN is an uneven-aged ponderosa pine sawtimber stand within the Norbeck Special Component. These stands have adequately stocked understories which vary from 60 to 120 square feet of growing stock basal area. Intermediate cut to a GSL of 80 .

TZA is an uneven-aged ponderosa pine sawtimber stand with an adequately stocked understory in the special component. This stand varies from 60 to 120 square feet of growing stock basal area. Intermediate cut to a GSL of 80.

N60 is an uneven-aged ponderosa pine sawtimber stand to be managed for wildlife habitat within the Norbeck Wildlife Preserve in the Special Component. This stand has 60-120 square feet of growing stock basal area. Enter this stand with an intermediate cut to a GSL of 60 .

NOR is a two-storied ponderosa pine stand in the Norbeck Wildlife Preserve Special Component. It has an adequately stocked overstory and understory. The overstory will be removed in two cuts to minimize damage to the understory. The second cut (seed cut) will be made in the overstory.

\section{Computation of Log Size Distribution}

As mentioned in the main text, timber class P31 is representative of the all-size group of timber classes, and timber class PB1 is representative of the sawtimber group of timber classes. Each of these timber classes is composed of trees with a distinctive distribution of diameters (figure 3). If a tree height distribution is available or can be reasonably estimated, then the diameters of logs cut from such trees may be estimated by means of taper tables. This was essentially the process used here to estimate one possible distribution of veneer block diameters.

To start, construct a probable estimated tree height distribution based on stand type and mean height for each tree diameter class. Table A-1 shows the results for timber class P31, and table A-2 shows the same information for timber class PB1.

Relative tree height within a diameter class in a timber stand depends largely on the age structure of the stand. In contrast, relative tree height for cut trees in a harvested timber stand depends on the silvicul- 
Table A-1.-Average tree heights and one possible distribution of estimated tree heights for timber class P31

\begin{tabular}{|c|c|c|c|c|c|c|c|c|}
\hline \multirow[t]{2}{*}{$\begin{array}{c}\text { Tree d.b.h. } \\
\text { classes } \\
\text { (2.inch classes) }\end{array}$} & \multicolumn{2}{|c|}{$\begin{array}{c}\text { Average } \\
\text { tree } \\
\text { height }\end{array}$} & \multirow[t]{2}{*}{$\begin{array}{c}\text { Trees } \\
\text { per } \\
\text { acre }\end{array}$} & & \multicolumn{3}{|c|}{ Tree heights in distribution' } & \\
\hline & feet $t^{2}$ & $\log s^{3}$ & & & & & & \\
\hline $\begin{array}{l}6 \\
8\end{array}$ & $\begin{array}{l}43.9 \\
51.9\end{array}$ & $\begin{array}{l}0.5 \\
1.0\end{array}$ & $\begin{array}{l}40.0000 \\
33.0000\end{array}$ & & $\begin{array}{r}0(0.25) \\
0.5(0.25)\end{array}$ & $\begin{array}{ll}0.5 & (0.5) \\
1.0 & (0.5)\end{array}$ & $\begin{array}{l}1.0(0.25) \\
1.5(0.25)\end{array}$ & \\
\hline 10 & 55.4 & 1.5 & 28.6591 & $0.5(0.1)$ & $1.0(0.2)$ & $1.5(0.4)$ & $2.0(0.3)$ & \\
\hline 12 & 62.3 & 2.0 & 17.6607 & $1.0(0.1)$ & $1.5(0.2)$ & $2.0(0.4)$ & $2.5(0.2)$ & $3.0(0.1)$ \\
\hline 14 & 66.8 & 2.5 & 9.1672 & $1.5(0.1)$ & $2.0(0.2)$ & $2.5(0.4)$ & $3.0(0.2)$ & $3.5(0.1)$ \\
\hline 16 & 70.0 & 3.0 & 4.3085 & $2.0(0.1)$ & $2.5(0.2)$ & $3.0(0.4)$ & $3.5(0.2)$ & $4.0(0.1)$ \\
\hline 18 & 76.6 & 3.5 & 2.1053 & $2.5(0.1)$ & $3.0(0.2)$ & $3.5(0.4)$ & $4.0(0.2)$ & $4.5(0.1)$ \\
\hline 20 & 78.1 & 3.5 & 0.7068 & $2.5(0.1)$ & $3.0(0.2)$ & $3.5(0.4)$ & $4.0(0.2)$ & $4.5(0.1)$ \\
\hline 22 & 85.0 & 4.0 & 0.3304 & $3.0(0.1)$ & $3.5(0.2)$ & $4.0(0.4)$ & $4.5(0.2)$ & $5.0(0.1)$ \\
\hline 24 & 88.1 & 4.5 & 0.1222 & $3.5(0.1)$ & $4.0(0.2)$ & $4.5(0.4)$ & $5.0(0.3)$ & \\
\hline 426 & 88.0 & 4.5 & 0.0769 & & & & & \\
\hline
\end{tabular}

'Two numbers appears in each column. The first number, without parentheses, tells the number of 16-foot logs found in that tree d.b.h. class. The second number, within parentheses, tells what proportion of trees in the given d.b.h. class are assumed to have that number of 16-foot logs. For example, trees in the 10-inch d.b.h. class are assumed to have $40 \%$ of their number with 1.516 -foot logs.

'Source: Computer program GROW printout. Information used as input to Black Hills NF Timber Management Plan, 1977-1986. On file, Rocky Mountain Forest and Range Experiment Station.

${ }^{3}$ Conversion from tree height in feet to tree height in merchantable 16-foot logs based on information in Van Deusen (1967).

'Taper information was not available for this diameter class. Effects of dropping this class are negligible.

Table A-2.-Average tree heights and one possible distribution of estimated tree height for timber class PB1

\begin{tabular}{cccccccc}
\hline $\begin{array}{c}\text { Tree d.b.h. } \\
\text { classes } \\
\text { (2.inch classes) }\end{array}$ & $\begin{array}{c}\text { Average } \\
\text { tree } \\
\text { height }\end{array}$ & $\begin{array}{c}\text { Trees } \\
\text { per } \\
\text { acre }\end{array}$ & & & & & \\
&
\end{tabular}

'Two numbers appears in each column. The first number, without parentheses, tells the number of 16-foot logs found in that tree d.b.h. class. The second number, within parentheses, tells what proportion of trees in the given d.b.h. class are assumed to have that number of 16-foot logs. For example, trees in the 10-inch d.b.h. class are assumed to have $40 \%$ of their number with 1.516 -foot logs.

'Source: Computer program GROW printout. Information used as input to Black Hills NF Timber Management Plan, 1977-1986. On file, Rocky Mountain Forest and Range Experiment Station.

${ }^{3}$ Conversion from tree height in feet to tree height in merchantable 16-foot logs based on information in Van Deusen (1967).

"Taper information was not available for this diameter class. Effects of dropping this class are negligible. 
tural prescription for the stand and on the judgment of the timber cruiser in selecting trees to match the prescription.

Height data from about 400 trees from timber sales in the Black Hills NF suggests that distributions of cut tree height on that National Forest are approximately symmetric about the mean height for a particular tree diameter class. In addition, while data are not available, it is assumed that the distribution of tree heights within a diameter class is wider for an uneven-aged stand than for an even-aged stand. Thus, timber class P31, an uneven-aged stand, is given a wider distribution than timber class PB1, a two-storied, even-aged stand.

Based on the information in tables A-1 and A-2, the next step is to consult a taper table for the sawtimber trees (Woodfin 1960) and for the poletimber trees (Myers 1963). For each tree diameter and height combination, the taper table will supply data on number and small end diameter, inside bark, of veneer blocks, each 8.5 feet long, that can be bucked from the tree.

A tree from a given height and diameter class would supply veneer blocks in several small end d.i.b. classes, based on the taper tables cited above. When these numbers of veneer blocks are multiplied by trees per acre in the height and diameter class, the result is number of logs per acre, by small end d.i.b. class, from trees within the given height and diameter class. Then logs per acre in each d.i.b. class are summed for all tree height and diameter classes. The result is an estimate of the distribution, by small end d.i.b. class, of the veneer blocks and other logs that can be obtained from the timber class.

The d.i.b. distribution of logs from each timber class is weighted by the acreage of each timber class to arrive at an overall d.i.b. distribution of available logs. In this case, as stated in the main text, the acreage of timber classes P31 and PB1 are about equal, so the distributions from each timber class were merged with equal weights. The net result is an estimate of a likely distribution of small end d.i.b.'s shown in figure 4 for 8.5-foot logs.

\section{ECONOMICS}

\section{Computation of Veneer Recovery}

To estimate veneer recovery volumes and associated residue volumes, a set of relationships was developed to relate total veneer block volumes to published veneer recovery studies. The basic relationship is that volumes for all losses, such as roundup and clipper losses, volumes for green veneer, and volumes for the block core must sum to the total block volume. In addition, estimates for each volume component of the block must conform reasonably well with volumes reported in published recovery studies (Yerkes and Woodfin 1972, Woodfin 1973).

\section{Residue Volume}

Green residue volume results mainly from block roundup and from losses at the clipper. Roundup loss is mainly a function of tree form, log diameter, and resultant taper. Clipper loss can result from a wide variety of physical and biological factors that degrade green veneer. This loss volume is also a function of block diameter to the degree that some veneer degrade factors are functions of block size, or position in the tree. In addition, some good veneer occasionally is lost by clipper malfunction. Published loss data (Yerkes and Woodfin 1972) shown in figure A-1 suggest that a quadratic equation might fit the data. A linear regression analysis resulted in the equation

$$
V_{\text {loss }}=0.0420 d^{2}-0.5634 d+2.912
$$

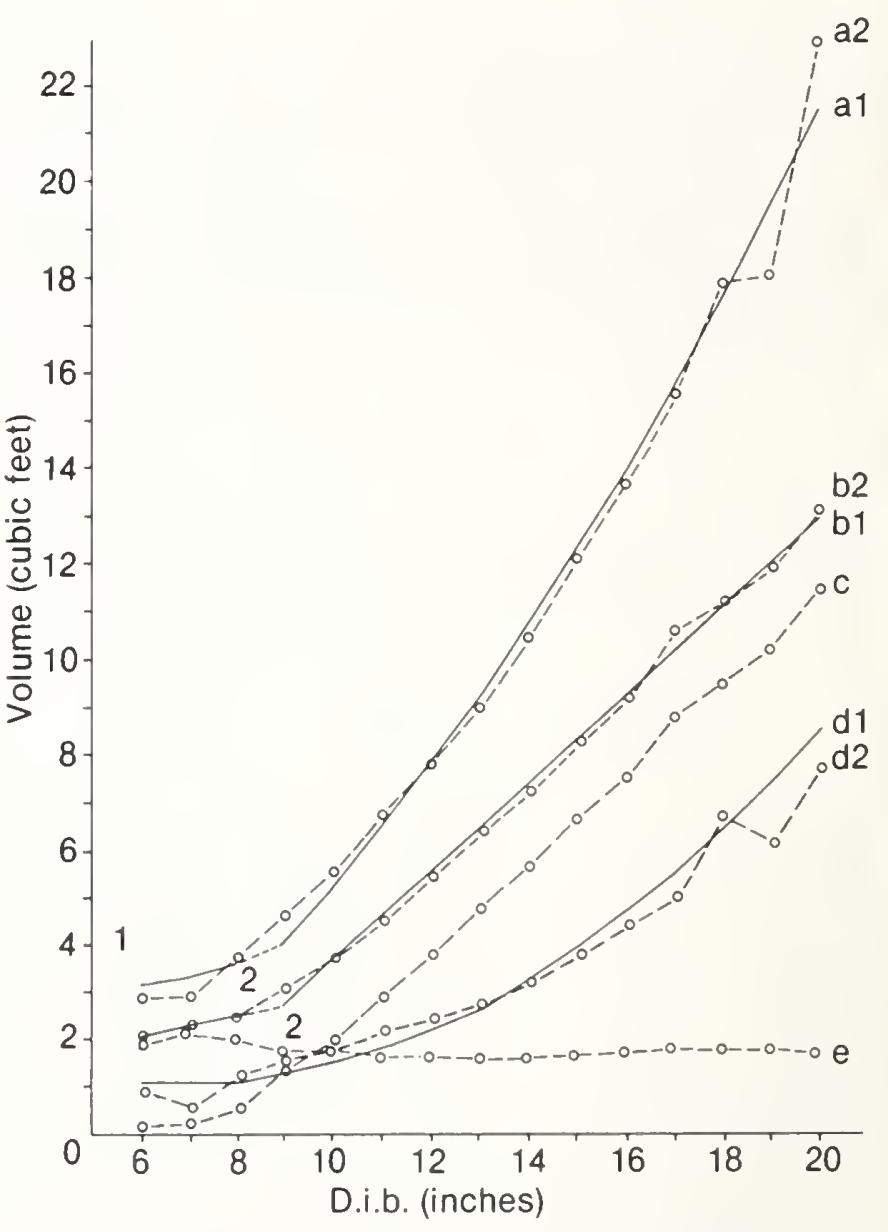

Figure A-1. - Veneer block component volumes by diameter class, Black Hills ponderosa pine (Yerkes and Woodfin 1972). Legend for the respective curves: $a 1$ = sum of regressions for veneer, core, and loss volumes; a2 = data points for sum of veneer, core, and loss volumes; b1 = regression for veneer plus core volumes; $b 2$ = data points for veneer plus core volumes; $c=$ data points for veneer volume; $\mathrm{d} 1$ = regression for residue loss volume; $d 2$ = data points for residue loss volume; $e=$ data points for core volume. Dotted portion of lines a1 and b1 show break between two separate regressions. 
where $d$ is veneer block small end diameter inside bark ${ }^{8}$ and $V_{\text {loss }}$ is cubic foot volume lost.

\section{Total of Veneer and Core Volume}

This volume is the block volunie net of all losses discussed above. Again, published recovery data were obtained from Yerkes and Woodfin (1972). The resulting regression equations are

$$
\begin{array}{ll}
V_{v c 9+}=0.9287 d-5.6184 & d \geqslant 9 \text { inches } \\
V_{v c 6-8}=0.2400 d+0.5900 & d=6,7,8 \text { inches }
\end{array}
$$

where $V_{v c 9+}$ is cubic foot volume in veneer $(v)$ plus core (c) from blocks 9 inches and greater, and $V_{v c 6-8}$ is cubic foot volume in veneer $(\mathrm{v})$ plus core $(\mathrm{c})$ from blocks 6 to 8 inches in diameter. The published data points for veneer and core (curve b2 in fig. A-1) show a distinct break between 8 and 9 inches. On each side of this break, the data points are almost linear. The simplest way to approximate these data points is by two linear equations for the block diameter ranges noted above. ${ }^{9}$

\section{Total Volume}

Total block volume is found by adding the respective volumes for losses and for veneer plus core, as computed by regression. Thus, total volume is completely accounted for and is expressed by the following equations:

$$
\begin{array}{ll}
V_{+9+}=0.0420 d^{2}+0.3653 d-2.6972 & d \geqslant 9 \text { inches } \\
V_{+6-8}=0.0420 d^{2}-0.3234 d+3.5112 & d=6,7,8 \text { inches }
\end{array}
$$

where $d$ is veneer block small end diameter inside bark in inches and $V_{+x x}$ is total veneer block cubic volume. An alternative method is to compute a regression equation for total veneer block volume as a function of block diameter. Data for this method would not be the sum of veneer, core, and residue; instead the data would be total block volume as reported by Yerkes and Woodfin (1972). This method, however, would lead to small discrepancies between total block volume computed by a regression formula and total block volume as the sum of the block component volumes. To be consistent total volume was computed on the basis of the sum of component volumes.

\footnotetext{
'This regression and all following equations are based on published summaries of recovery data. The equations are used here as computational aids for analysis of the timber resource. As seen in figure $A-1$, the regressions generally fit the data points. The authors do not suggest that these equations are necessarily applicable beyond the analysis reported here.

'A single regression equation may fit these data points with a high coefficient of determination $\left(r^{2}\right)$. However, such an equation would erroneously estimate volume for 8-inch veneer blocks. Because this size block is represented in the diameter distribution to a far greater extent than other diameters, this defect is serious. For this reason, two separate equations were used.
}

\section{Core Volume and Green Veneer Volume}

Core volume is based on the formula for a cylinder. Length assumed is 8.5 feet for each veneer block. After allowing for the appropriate unit conversion factors the following equation results:

$$
V_{c}=0.046359 d_{c}
$$

where $d_{c}$ is the target core diameter in inches, and $V_{c}$ is cubic foot volume in the core. Target diameters used in this study and the corresponding volumes for veneer lathe cores are shown below.

$\begin{array}{cc}\begin{array}{c}\text { Target core } \\ \text { diameter }\end{array} & \begin{array}{c}\text { Core } \\ \text { volume }\end{array} \\ \text { inches } & \text { cubic feet } \\ 6 & 1.6689 \\ 5 & 1.1590 \\ 4 & 0.7417\end{array}$

Green veneer volume is computed by subtracting the respective core volume from the volume for green veneer and core.

\section{Veneer Shrinkage and Dry Veneer Volume}

Shrinkage volume is based on percent factors published by Woodfin (1973). The percent shrinkage of veneer by block diameter class is applied to the total block volume, computed as indicated above. The resultant cubic volume of shrinkage is then subtracted from each appropriate green veneer volume to arrive at the figure in table 13 for cubic volume of dry veneer.

\section{Computation of Log Taper}

Low-taper logs.-Work completed by Myers (1963) for ponderosa pine in the Southwest is the source of taper data for pole-sized trees that most closely resemble Black Hills ponderosa pine. Taper for 8-foot logs ranged from 0.4 to 1.9 inches, depending on diameter, tree height, and log position in the bole. Average taper for each 1-inch class of log diameter, inside bark, varies from 0.95 to 1.18 inches per 8 -foot log. Average taper for all logs is 1.01 inch per 8-foot log. Based on the above information, it was assumed that taper in logs from poletimber trees averages 1 inch per 8.5 -foot $\log$.

High-taper logs.-As noted in the main text, these logs are bucked mostly from the top of the bole of sawtimber-sized trees. Taper data for ponderosa pine sawtimber trees in the Black Hills was compiled by Woodfin (1960). Analysis of these data reveal a wide variation in taper, as would be expected. When the data for 8.5-foot logs are aggregated by 1-inch small end d.i.b. classes, average taper is shown in the following tabulation: 
Log small end
diameter class

inches

6

7

8

9

\section{Taper per \\ 8.5-foot log}

inches

3.4

2.6

2.0

1.8
These results are consistent with expectation. Six-inch logs are located in the rapidly tapering bole top. Logs of larger diameter would be located farther down the bole where taper is less than at the top.

\section{Lumber and Residue Recovery}

Smalian's formula, modified to reflect the assumed taper per 8.5-foot log, was used to compute total log volume. The resulting formula is:

$$
V_{L}=0.046359\left(d^{2}+d t+0.5 t^{2}\right)
$$

where $V_{L}$ is log volume in cubic feet, $d$ is log small end d.i.b. in inches, $t$ is $\log$ taper in inches per 8.5 feet, and 0.046359 is the appropriate conversion factor for units computed as 0.005454 square feet per square inch $\times 8.5$ feet. Six decimal places does not imply extreme accuracy, but rather, minimizes rounding error.

Dimension 2- by 4-inch lumber produced by the auxiliary sawmill with chipping headrig is assumed to have the following cross sectional dimensions, depending on its degree of manufacture:

\section{Condition}

Rough, green

Rough, dry

Dressed, dry

\section{Size}

inches

$1.65 \times 3.75$

$1.59 \times 3.63$

$1.50 \times 3.50$
Saw kerf, where it applies, is assumed to be 0.15 inch. Williston's (1976) recommended standard saw kerf of 0.125 inch was adjusted upward to assure a conservative estimate. Saw kerf sawdust volume is computed for the full log length of 8.5 feet because the 2- by 4 -inch lumber is not yet trimmed to 8 feet.

Chip volume is the log volume net of rough green lumber and saw kerf volumes.

Trim volume is the 0.5 foot of ends trimmed to make an 8-foot long stud. Shrinkage is volume lost during the drying process. Planer shaving volume includes planer shavings plus sander dust. Both shrinkage and planer shaving volumes are based on changes in cross sectional dimension shown in the tabulation above.

\section{Bark Volume}

Bark volumes per cubic unit of roundwood volume were estimated using factors published by Krier and
River (1968). These factors were given by 4-inch diameter classes for logs with diameters ranging from 7.6 to 35.5 inches. Because log diameter in the Black Hills is as small as 4 inches, the factor values were extrapolated to cover the entire range of Black Hills log sizes. Proportions of logs in each 4-inch diameter class were computed from data incorporated in figure 4 . Assuming that log diameters are distributed as shown in the figure, the weighted average bark volume factor is computed as shown in table A-3.

The total volume of 100 index logs, defined in the main text, is 424.4980 cubic feet. Multiplying this volume by the weighted average bark factor (0.236724) results in a bark volume of 100.4889 cubic feet per 100 index logs.

\section{Product Recovery for Index Log Volumes and Total Volume Required}

Units of one hundred logs, each log 8.5 feet long, whose small end diameters are distributed as shown in figure 4 , are estimated to provide the product volumes shown in tables A-4, A-5, and A-6.

Each table is organized to relate product recovery to three levels of target core diameter and to three levels of veneer block lower size limit. For example, the relationships illustrated in figure 6 are amplified in these tables. Lumber recovery from small logs shown in table A-5 depends only on choice of a lower diameter limit for veneer blocks, but lumber recovery from veneer block cores depends on both the lower veneer block diameter limit and on the target core size.

A most important question for the analysis of material flow is how many units of 100 index logs are required to support the plywood plant at the assumed capacity.

Dry veneer is used as the base product for computing volumes. The annual dry veneer requirement is $2,325,149$ cubic feet. The column in table A-4 for dry veneer lists cubic volume per 100 index logs. For example, when peeling 8-inch and larger logs to a 4-inch core, the number of units of 100 index logs required is computed by dividing 2,325,149 cubic feet required per year by 191.03 cubic feet per 100 index logs. The result is that 12,172 units of 100 index logs are required annually. Similar results are shown in table A-7 for each of the nine combinations of veneer block lower diameter limit and target core size.

The numbers of index units in table A-7 are termed blow-up factors. When the appropriate blow-up factor is multiplied by index volumes from tables A-4, A-5, and $A-6$, the annual requirements for raw material can be determined, as well as the annual production volumes of the various products and residues. The annual material volume flow is shown in table 15 for the analysis presented in this report, assuming a target core size of 4 inches and veneer block lower limit of 8 inches. 

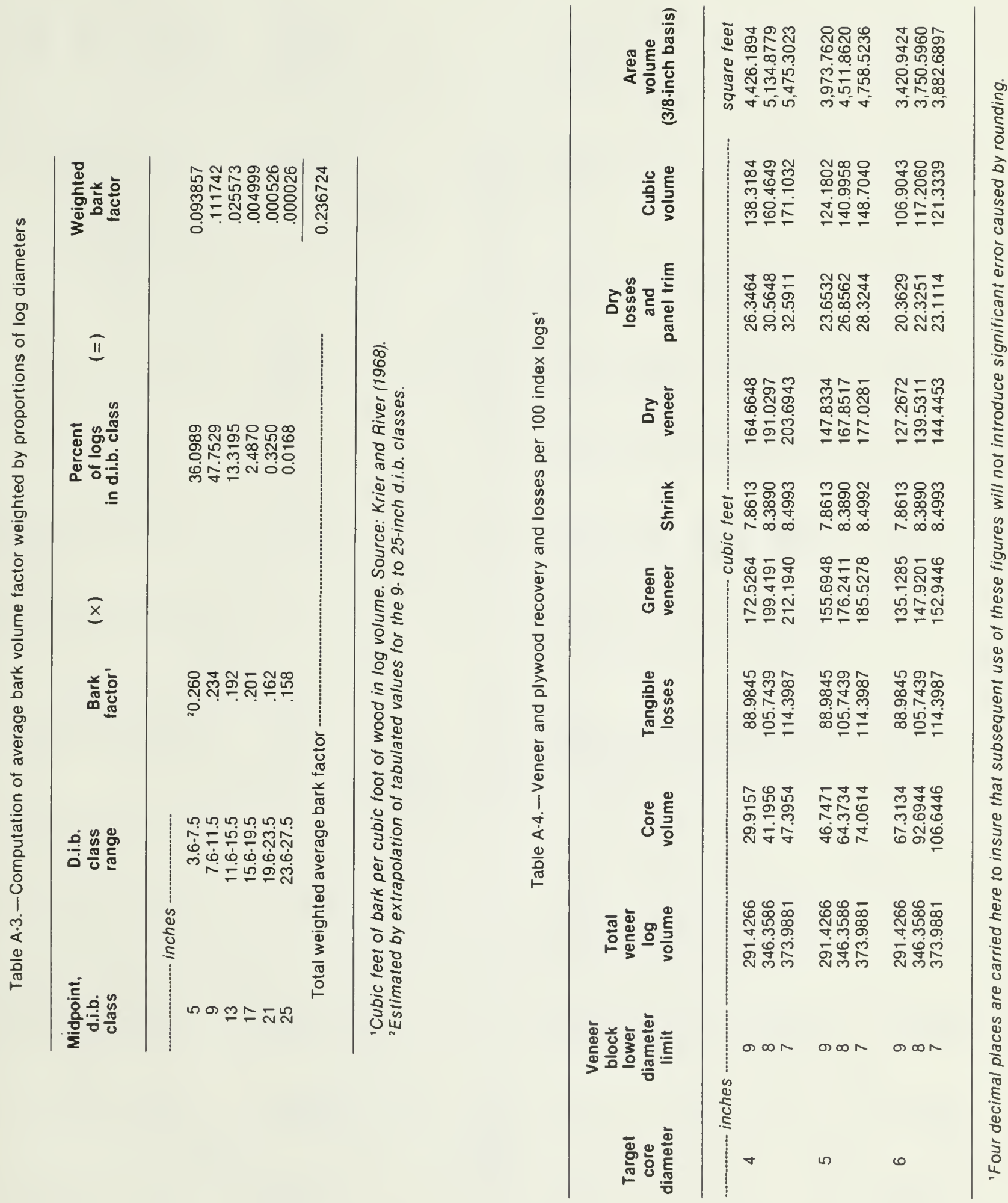


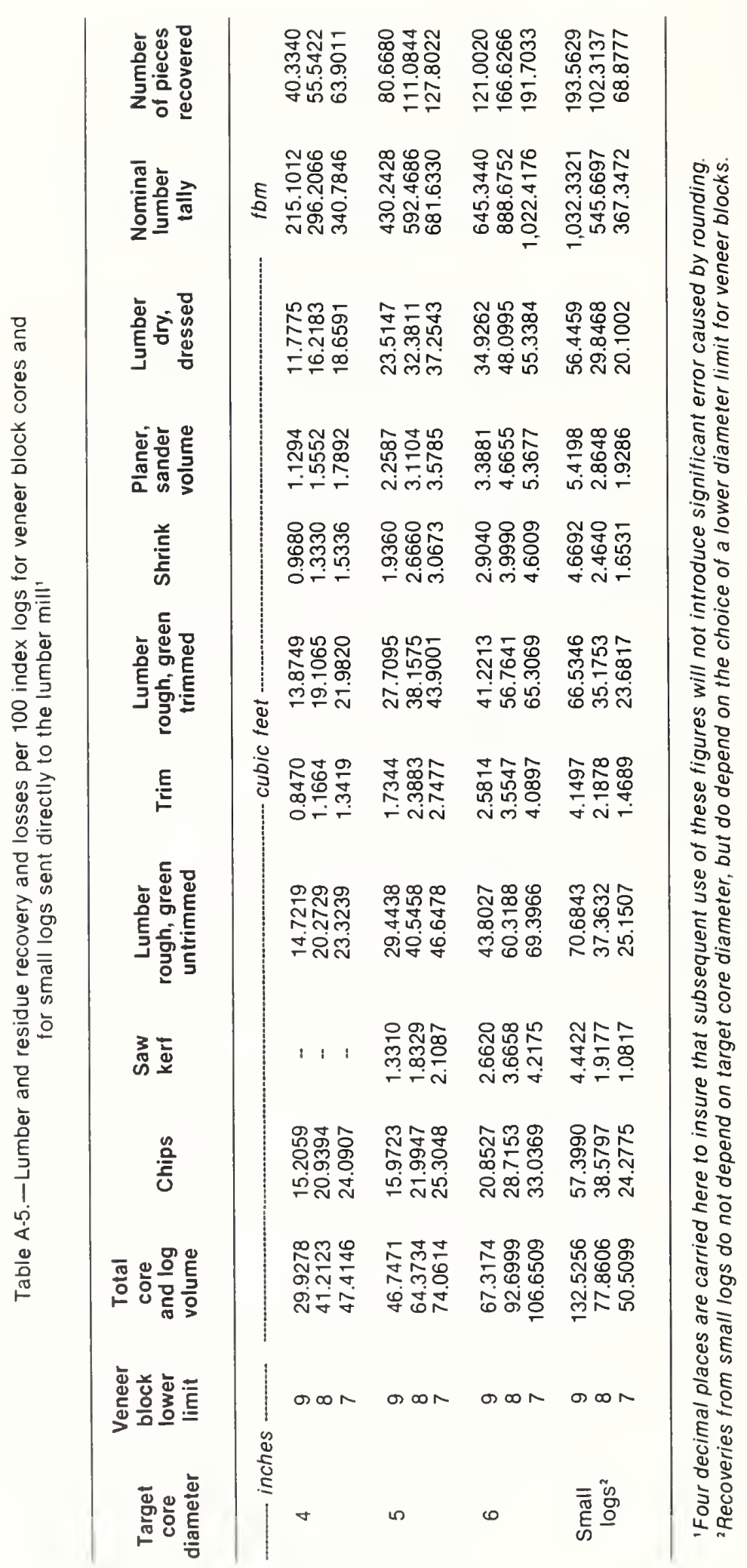

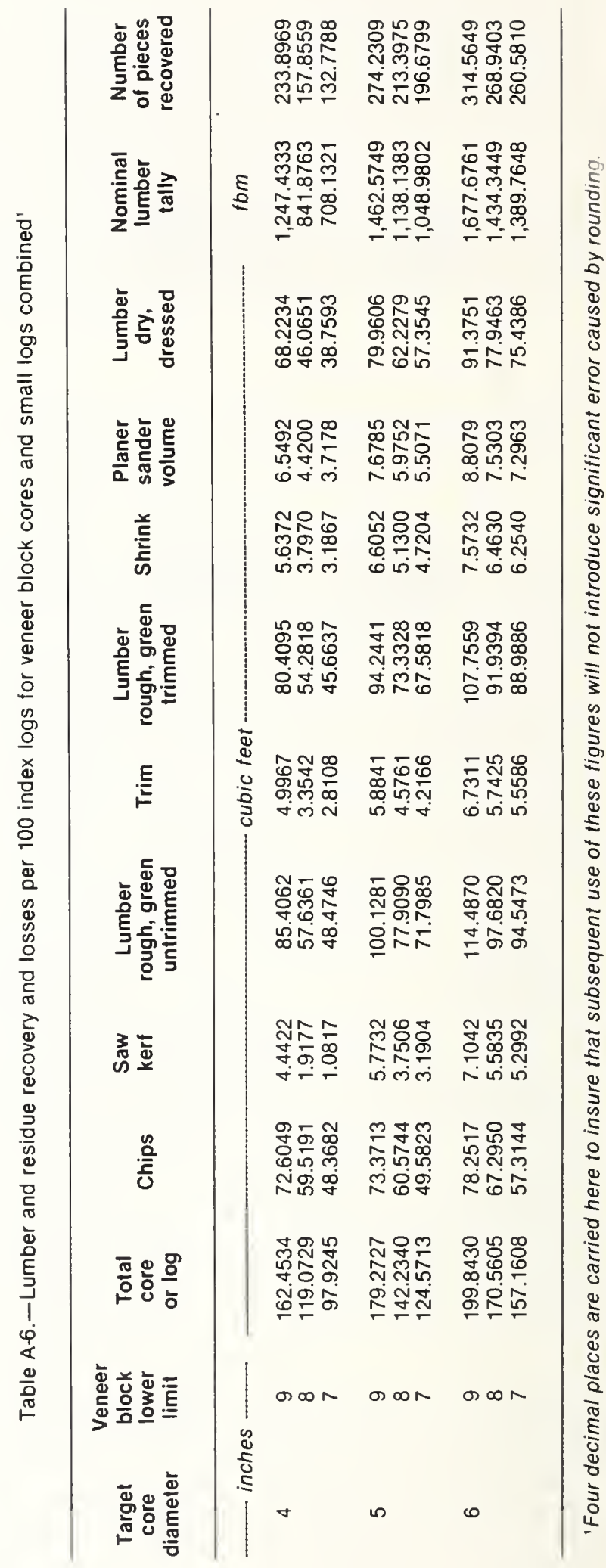


Table A-7.-Number of units of 100 index logs required to supply dry veneer required for capacity plywood plant operation

\begin{tabular}{cccc}
\hline $\begin{array}{c}\text { Veneer } \\
\text { block } \\
\text { lower } \\
\text { limit } \\
\text { (inches) }\end{array}$ & 6 & Target core size (inches) & \\
\cline { 2 - 4 } & & 5 & 4 \\
\hline 9 & $18,269.8198$ & & \\
\hline 8 & $16,664.0183$ & $15,728.1698$ & $14,120.4970$ \\
7 & $16,097.0887$ & $13,852.3748$ & $12,171.6613$ \\
& & $13,134.3265$ & $11,414.8938$ \\
\hline
\end{tabular}

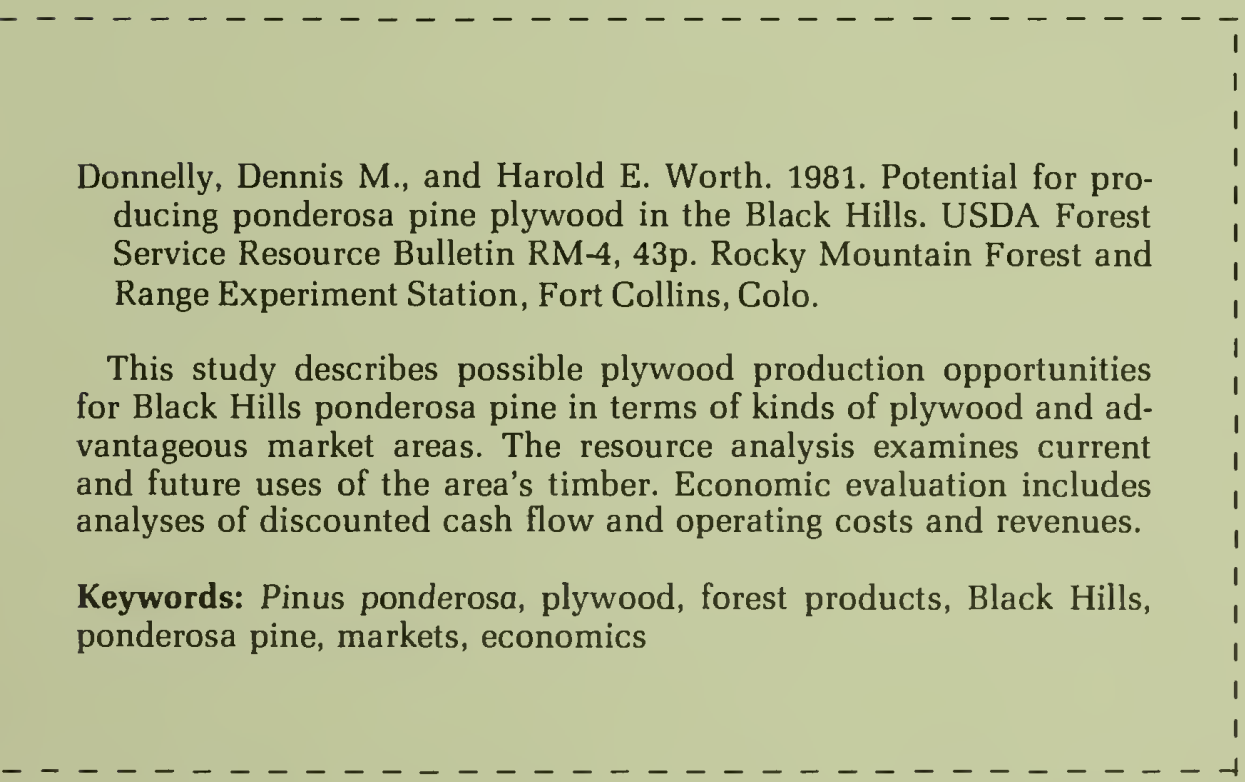




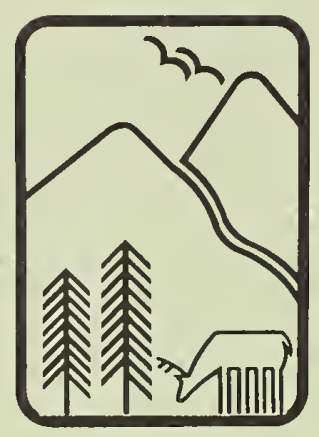

Rocky Mountains

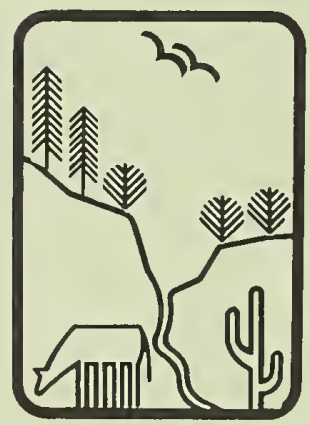

Southwest

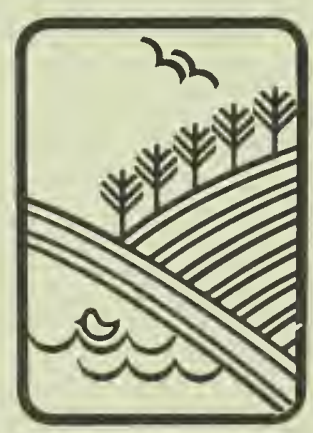

Great Plains
U.S. Department of Agriculture Forest Service

\section{Rocky Mountain Forest and Range Experiment Station}

The Rocky Mountain Station is one of eight regional experiment stations, plus the Forest Products Laboratory and the Washington Office Staff, that make up the Forest Service research organization.

\section{RESEARCH FOCUS}

Research programs at the Rocky Mountain Station are coordinated with area universities and with other institutions. Many studies are conducted on a cooperative basis to accelerate solutions to problems involving range, water, wildlife and fish habitat, human and community development, timber, recreation, protection, and multiresource evaluation.

\section{RESEARCH LOCATIONS}

Research Work Units of the Rocky Mountain Station are operated in cooperation with universities in the following cities:

Albuquerque, New Mexico

Bottineau, North Dakota

Flagstaff, Arizona

Fort Collins, Colorado

Laramie, Wyoming

Lincoln, Nebraska

Lubbock, Texas

Rapid City, South Dakota

Tempe, Arizona

- Station Headquarters: 240 W. Prospect St., Fort Collins, CO 80526 